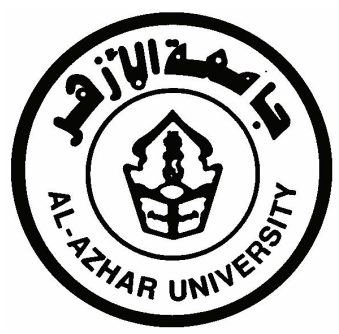

$$
\begin{aligned}
& \text { جامعست الأزهــــر } \\
& \text { كليـت أصــول الديـن } \\
& \text { والدعوة الإسلاميتَ بالمنوفيتي }
\end{aligned}
$$

\title{
الصعود بمعرفة أسباب الورود
}

\author{
إعداد الباحثان
}

$$
\text { الركتور }
$$
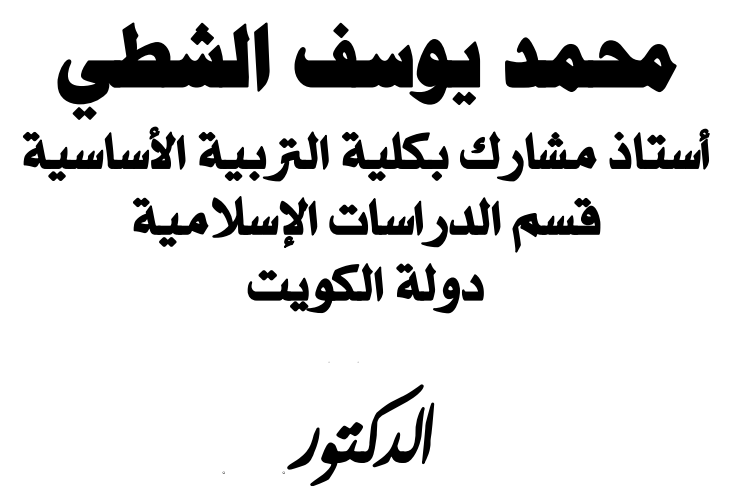

$$
\text { إبراهيم همثد هممد عبد العال المناوي الحمديث }
$$





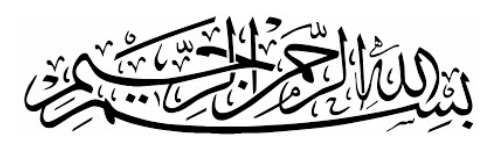

الحمد لله رب العالمين، له الحمد في الأولى و الآخرة، و الحمد لله الذي يسر

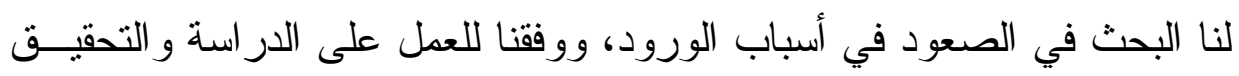

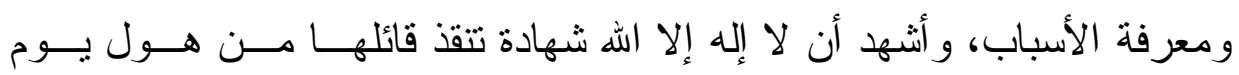

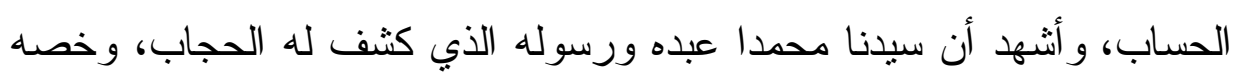

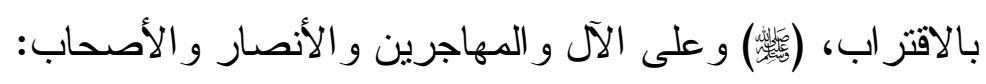

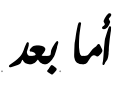

فإن أربح الأعمال أجر ا وأبقاها ذكر ا و أعظمها ثو ابا، كسب العلوم النافحسـة

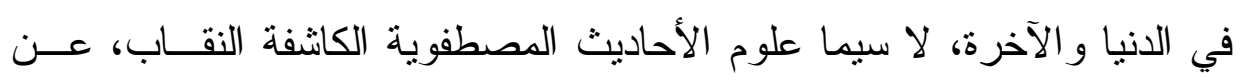

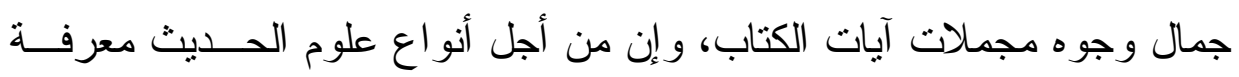

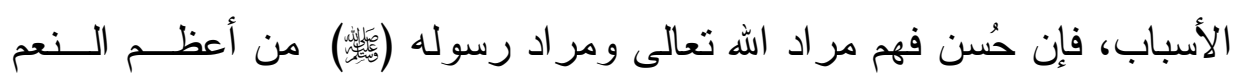

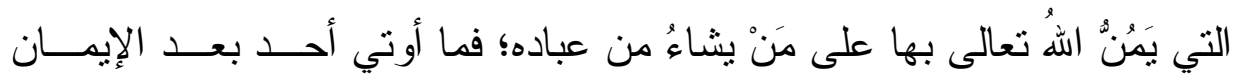

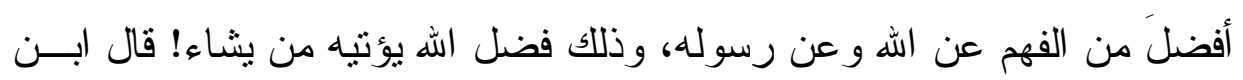

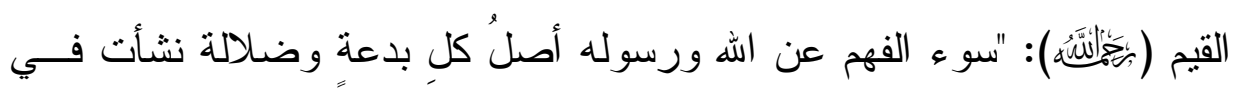

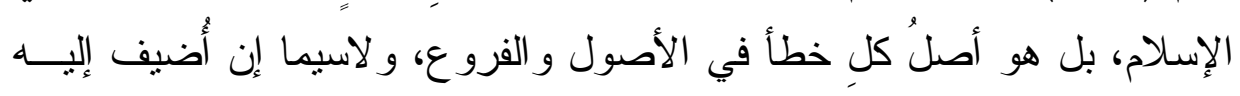
سوء القصد..." (1). (1)

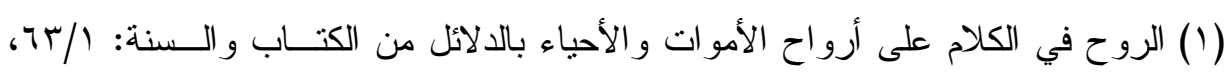
محمد بن أبي بكر بن أيوب بن سعد شمس الدين ابن قيم الجوزية، دار الكتب العلمية بيروت. 
وقد اكتملت شريعة الله سبحانه تعالى ببيان أصول الحلال و الحــر ام، بمــــا

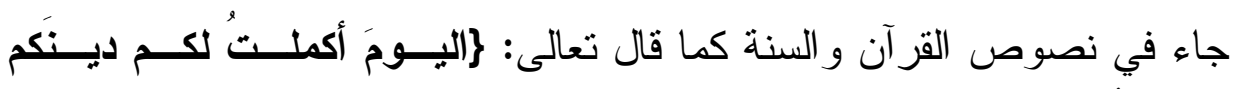

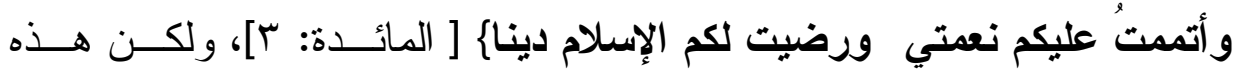

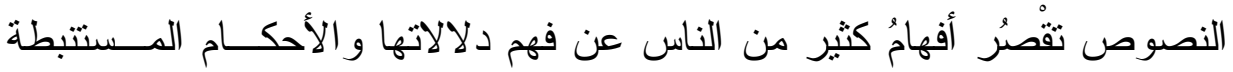

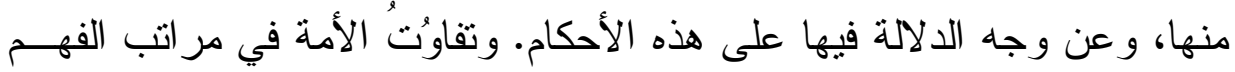

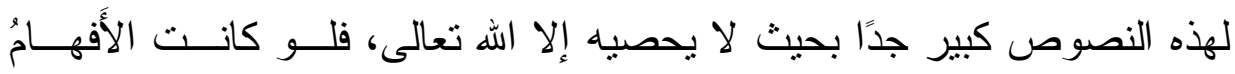

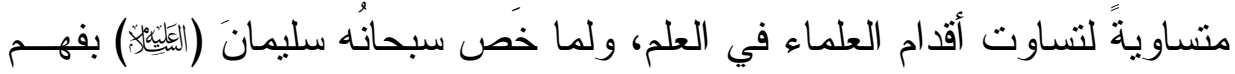

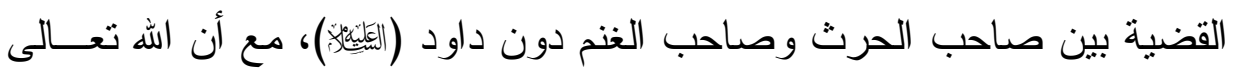

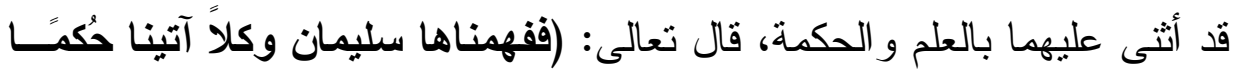

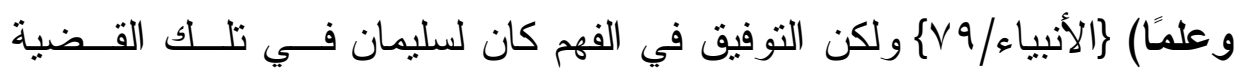
بخصوصها.

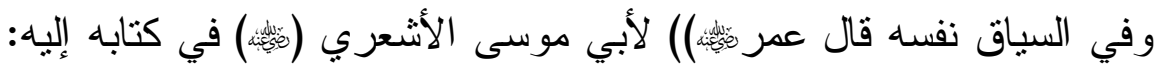

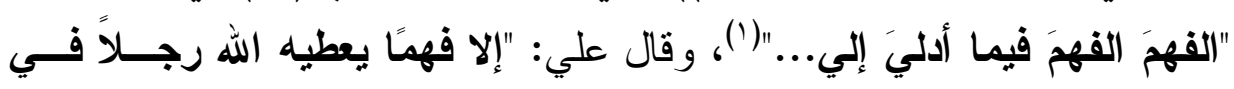

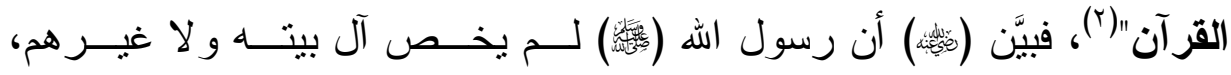

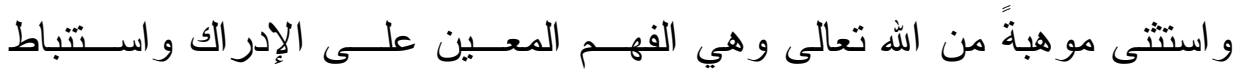

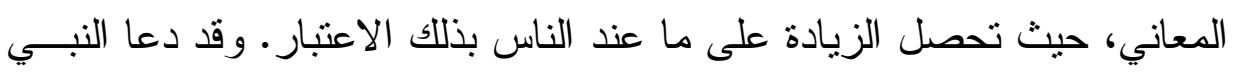

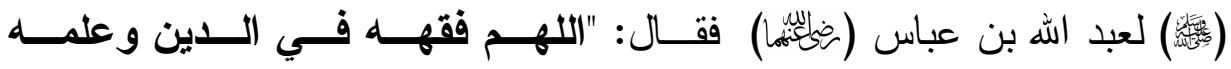

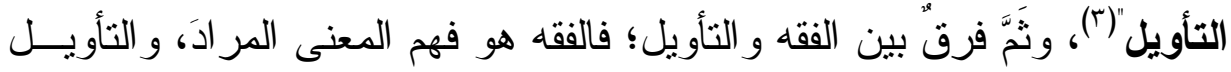

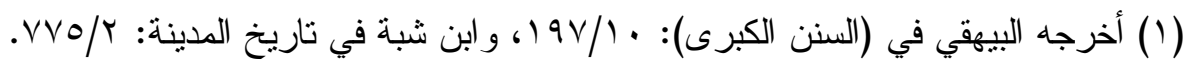

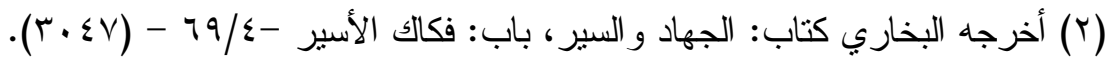

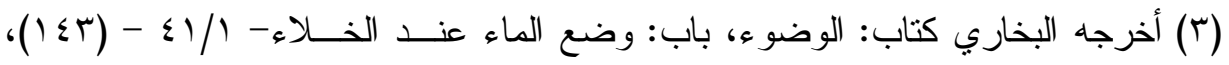

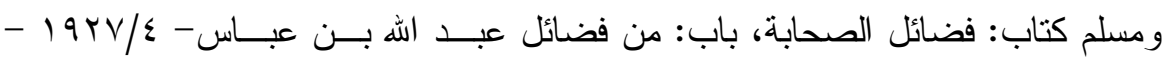


إدر الكُ الحقيقة التي يؤول إليها المعنى، وليس كلُ من فقه في الدين كان عالمَـــا بالتأويل، فالعلم بالتأويل يختص بـ الرؤه اسخون في العلم.

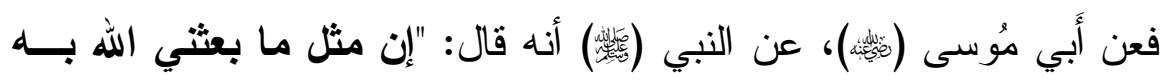

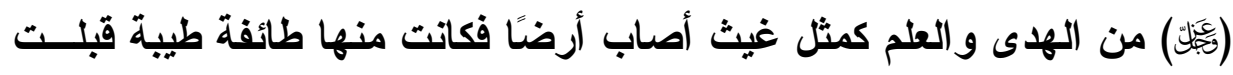
الماء فأنبتت الكلأ والعشب الكثير، وكان منها أجادبُ أمسكت الماء فنهـــع الله بها الناس فشربوا منها وسقَوا ورعَوا، وأصاب طائفة منها أخرى إنمـــا هـي

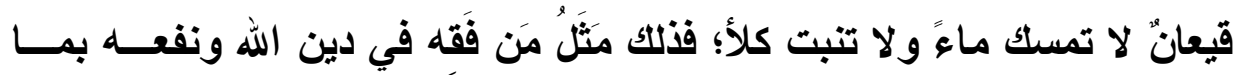

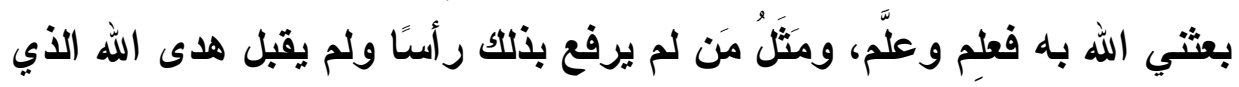

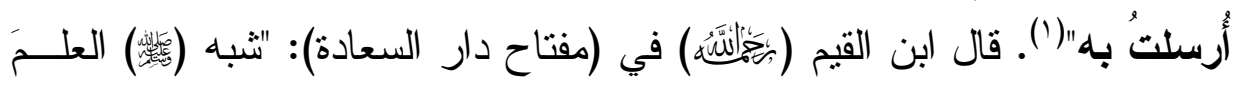

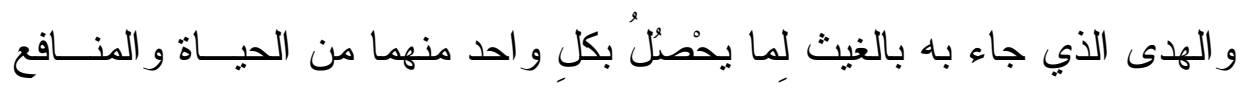

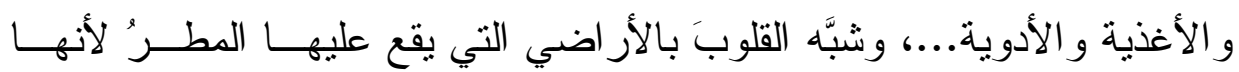

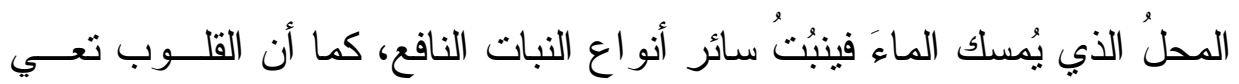

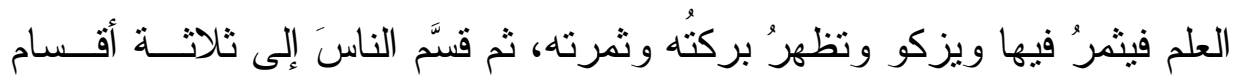

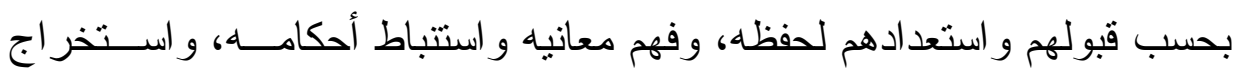
حكمه وفو ائده؛...الخ" (ب).

(1) أخرجه البخاري كتاب: العلم، باب: فضل من علم و علم- YV/ - Y (V9)، ومسلم كتاب:

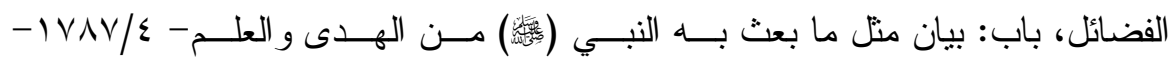
( $($ YAY)

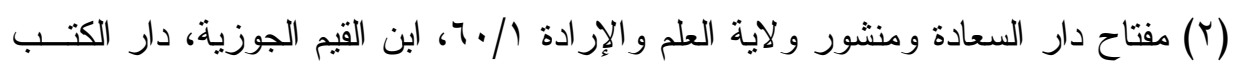
العلمية - بيروت. 
أولا: أهمية الموضوع:

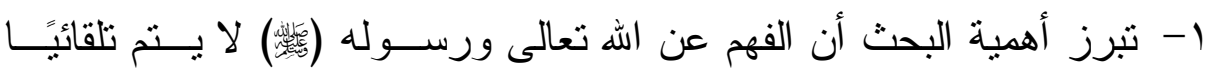
بمجرد النظر المتعجل في نصوص الوحيين كما قد يظن بعض الناس، نعم بعضُ النصوص و اضحُ الدلالة كالثمس في ر ابعة النهار ، كقولــهـ تعــالى \}الله لا إله إلا هو الحي القيوم\{ \}آل عمران: برولكن بعضها الآخر ليس

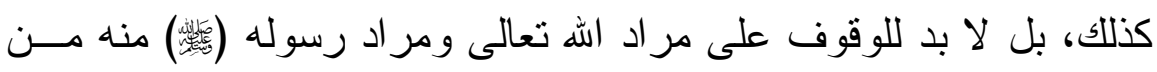

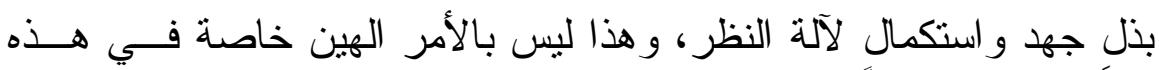
العصور المتأخرة التي ضعفت فيها الهِمِ و الملكــات العلميـــة و القــدر ات اللغوية.

ץ- من يستقر أ النصوص في الوحيين يجد أولاً من الإيمان المطلق بــأن تلـــــ

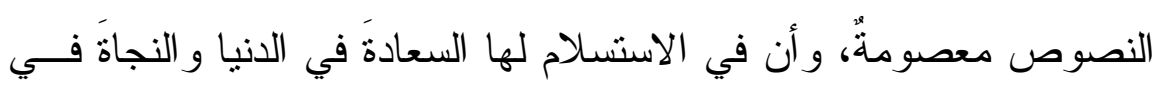

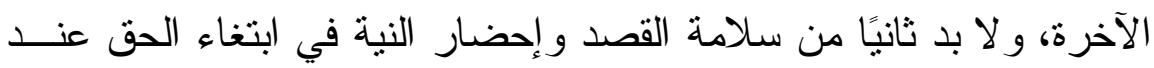
نظر المجتهد في تلك النصوص، ثم لا بد ثالثًا من استكمال آلــة الاجتهــاد و استيفاء الثروط التي يذكر ها العلماء فيمن ينظر في نــصوص الــوحيين لاستتباط ما تدل عليه من حكمٍ و أحكام.

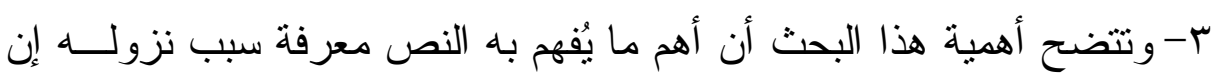

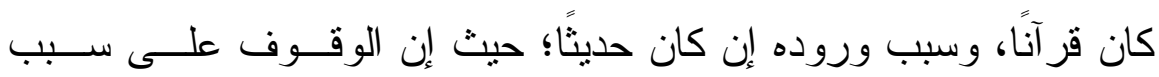

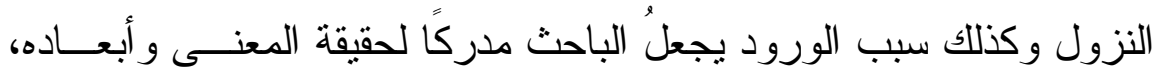
و عارفا لوجه الارتباط بين النص و الحُكم المستتبَط منــه، و الحكمــة التـي تكون في هذا الارنباط، وهذا يعين المجتهدين في كل عصر علــى إدر الك

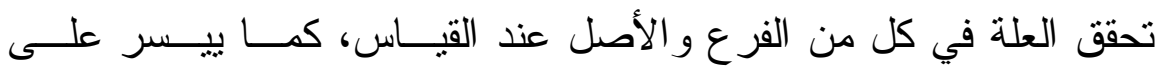
المجتهدين الوقوفَ على ظهور الحكمة عند استتباط الأحكــام للمـشكلات 
الحادثة و النوازل المعاصرة، قال شيخ الإسـام ابن تيمية: "ومعرفـــة ســبـ

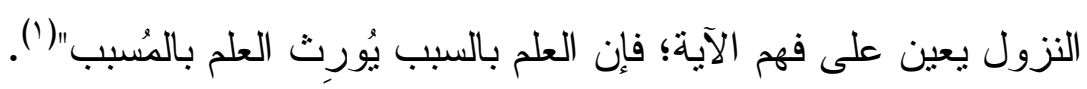

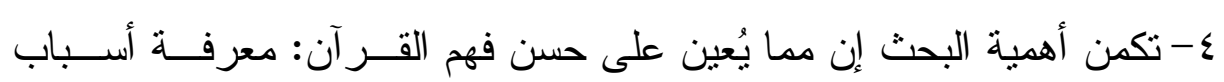

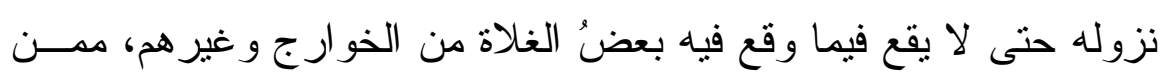
أخذو الآيات التي نزلت في المشركين وطبّقوها على المسلمين، ولهذا كان لنع ابنُ عمر ير اهم شرار الخلق بما حرفو الكتاب الهه عما أنزل فيه. فإذا كانت

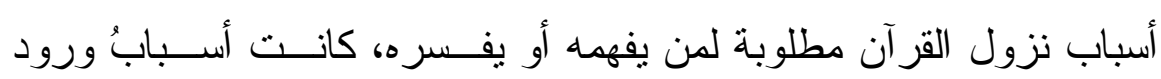
الحديث أثندّ طلبًا؛ ذلك أن القر آن بطبيعته عامّ وخالدُ، وليس من شــأنه أن أن

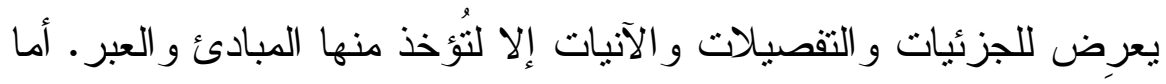
السنة فهي تعالج كثيرًا من المشكلات الموضعية و الجزئية و الآنية، وفيهــا

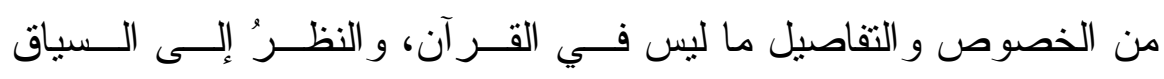
و الملابسات و الأسباب تساعد على سداد الفهم و استقامته لمن وفقَّه الله، ومن ون ون

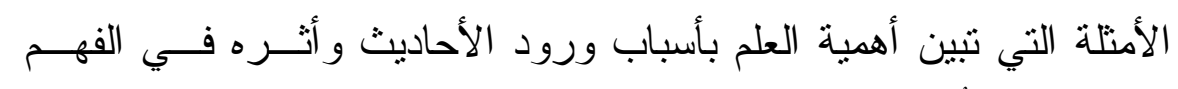

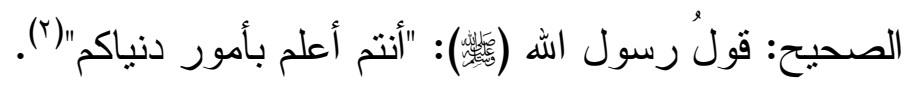

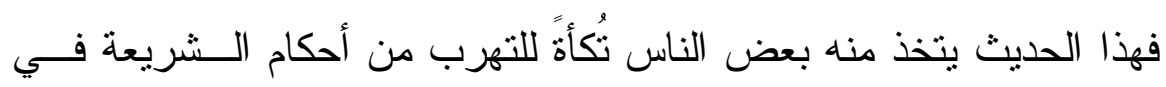

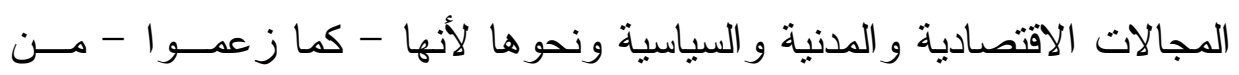

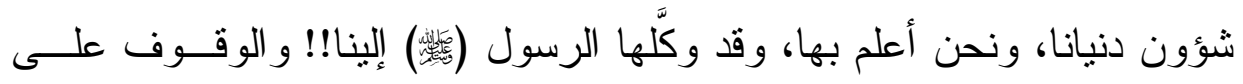

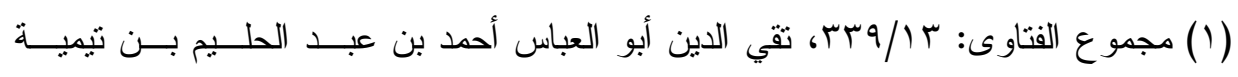

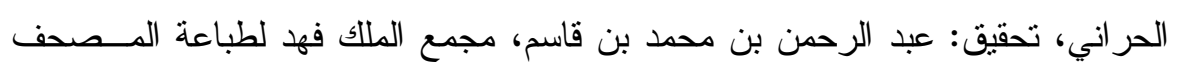

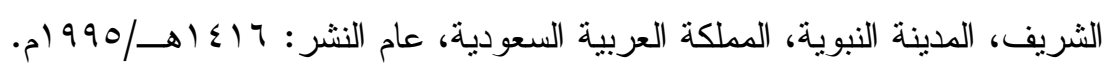

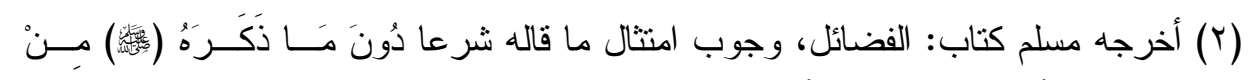

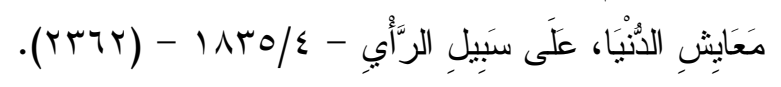


قصة هذا الحديث وسبب وروده يقطع الطريث على أمثال هؤلاء؛ فـسبب ورود هذا الحديث هو قصة تأبير النخل، و إثنارته عليه الصلاة و السلام عليهح بــر أي هوردي

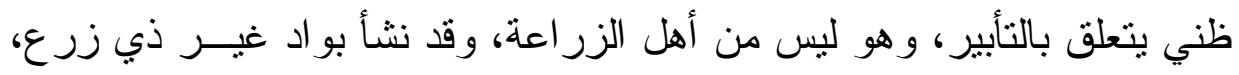

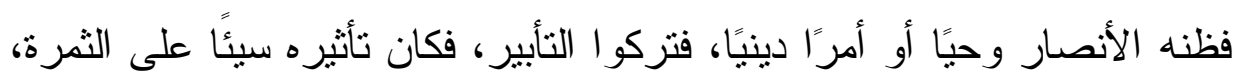

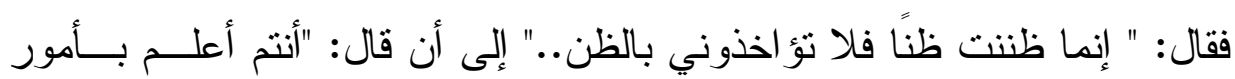
دنياكم".. فهذه هي قصة الحديث" ('). ه- ويتأكد أهمية هذا البحث في العلم بأن من الأسباب ما يكون بعـد عـصر

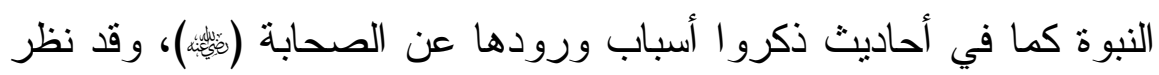
بعض المتأخرين في ذلك ولكن ذكرها أولى لأن فيه بيان السبب في الجملة

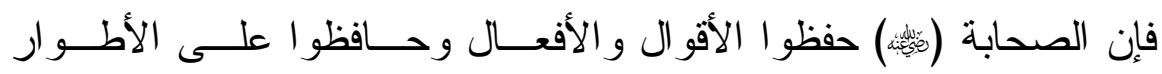

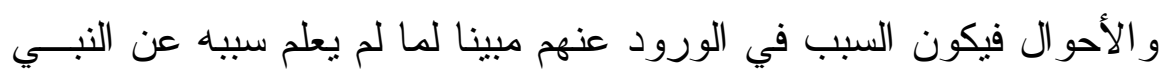

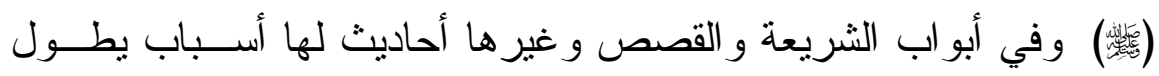
شر حها. ومما سبق يتبين لنا أهمية هذا العلم و الفو ائد المترنبة على العناية بــهـ فــي الوقوف على دلالات أحاديث رسول الهه (ئل).

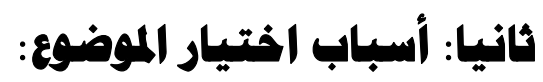

ترجع أسباب دراسة هذا الموضوع لعدة أمور منها: 1- أهمية الوقوف على أسباب الورود لفهم الحديث النبوي الثريف.

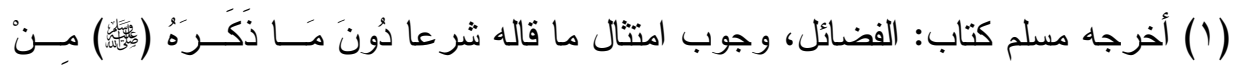

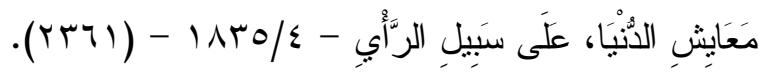




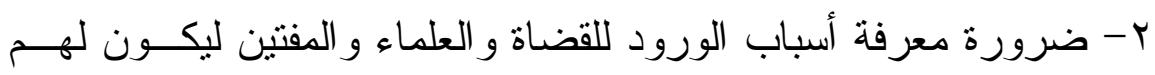
عونا للوقوف على الحكم الصحيح و المو افق للشريعة الإسلامية. r- معرفة العام والخاص، فقد يكون الحديث سيق لسبب خاص، لا ينطبق

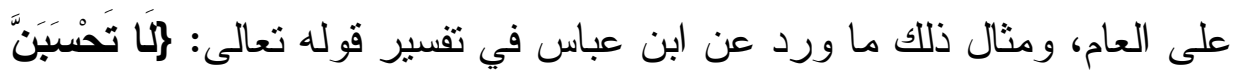

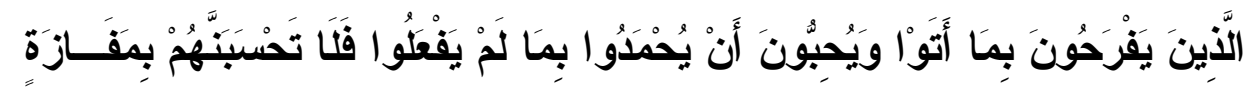

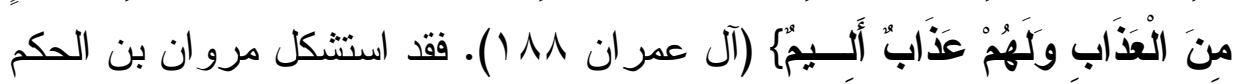

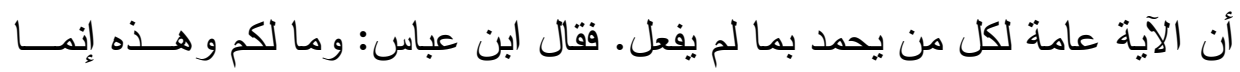

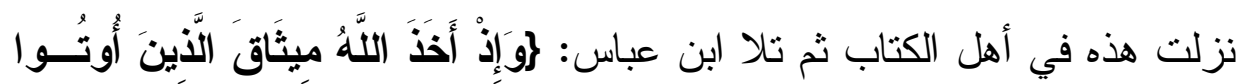

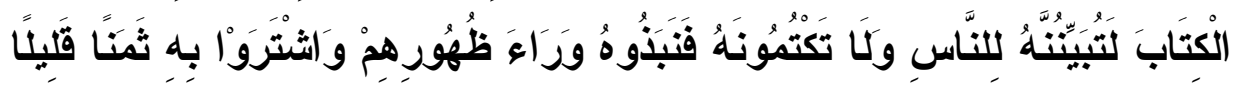

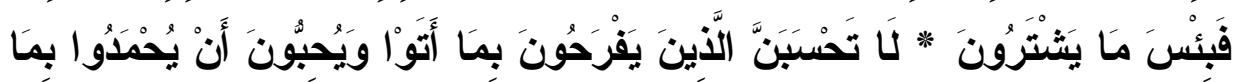

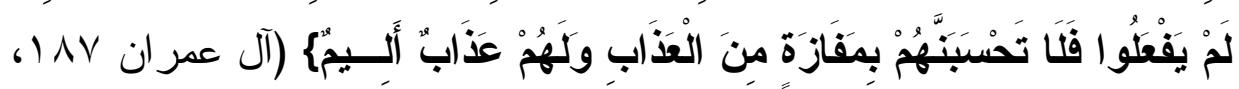

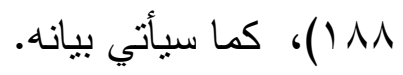

ع - تعديل ما هو متعارف عند العامة و الخاصة بالنــسبة للقاعــدة الفقهيــة "العبرة بعموم اللفظ لا بخصوص السبب" إلى "الأصل في النص هو عموم اللفظ لا خصوص السبب أو الورود إلا إذا كانا يخصصان المعنى أو الفعل".

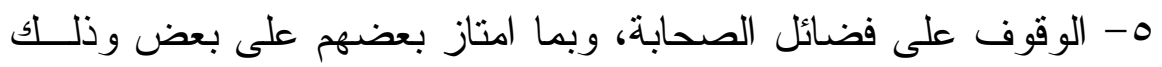
بالوقوف على أسباب الورود.

7- ومن أسباب اختيارنا لهذا الموضوع هو ما نر اه الآن من كثيــر مــن العلماء وطلاب العلم من إنز ال الأحاديث في غير منازلها، وســوق الأحاديـــث

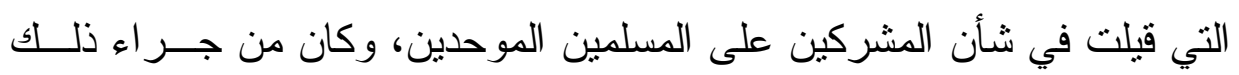

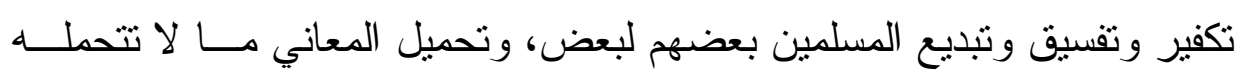
مقاصد السنة النبوية الشريفة . 


\section{ثالثا: الدراسات السابقة:}

هذا العلم من علوم الحديث النبوي الثريف، صنف فيه العلماء لما وقفــو ا على أهمية المعرفة بأسباب نزول القرآن الكريم في فهم مر اد اله تعــالى مسن الآيات القر آنية المرتبطة بأسباب نزولها، فثر ع بعض العلماء من أهل الحـديث

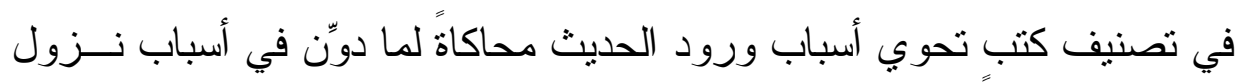
القرآن الكريم، ملتزمين منهجًا يقارب المنهج الذي انتهجه علماء التفسير و علوم القر آن في تدوين أسبابِ نزولِ آيات القرآن الكريم، ومن أهم ما تم تأليفـــهـ فــي

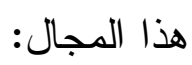

1- أسباب ورود الحديث -تحليل وتأسيس-《 للاكتور /محمد رأفت سعيد. ץ- 》امعرفة أسباب الحديثه رسالة ماجسنير على كتاب "اللمع فـي أســباب

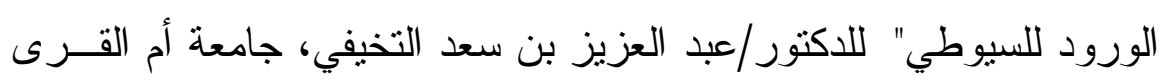

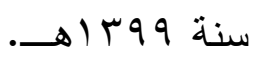

ץ- 》سبب ورود الحديث - ضو ابط ومعايير -《 لمفتي ولاية برليس الماليزية

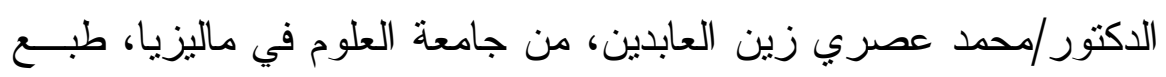
في مجلد و احد ضمن مطبو عات مكتبة الكتب العلمية. ع- "علم أسباب ورود الحديث، ومكانته، و أهميته في التـشريع الإســلامي" للاكتور /رمضان أيو اللي أرضروم، جامعة أتاتورك أنقرة.

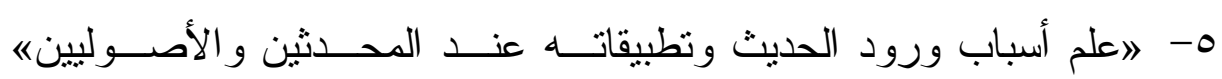
للاكتور/طارق أسعد حلمي الأسعد (طبعته دار ابن حزم). 


\section{الصعود بمعرفة أسباب الورود}

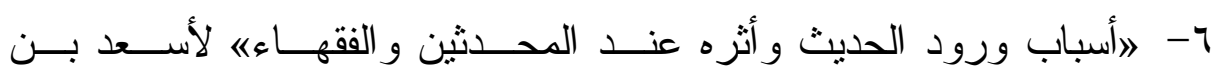
طارق،(جامعة محمد الخامس كلية الآداب، الرباط)، رسالة في نيل درجــة

$$
\text { الدكتور اه، (إنثر اف: فاروق بن محمود حماده). }
$$

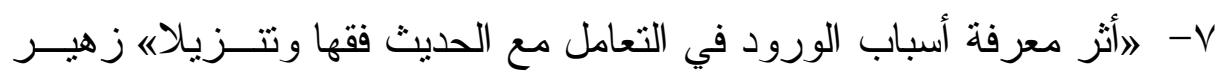

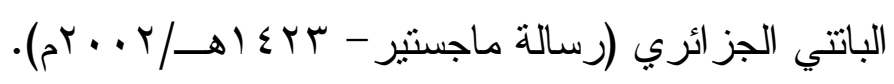

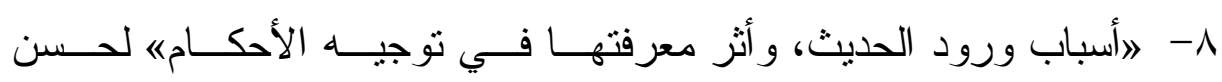

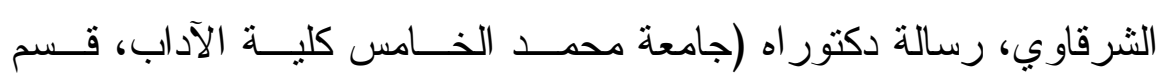
الدر اسات الإسلامية - الدار البيضاء) سنة 990 1، (إثر اف: زين العابدين

$$
\text { بلا فريج). }
$$

9- علم أسباب ورود الحديث للدكتور/بدر عبد الحميد هيسة. • 1 - أسباب ورود الحديث وأثز معرفتها في توجيه الأحكام حسسن الـشرقاوي جامعة محمد الخامس المغرب.

11 - أسباب ورود الحديث و أثزه في فقه الحديث.آسو رضا أحمد جامعة بغداد. r ا - علم ورود الحديث و أثره في فقه الحديث، بحث منشور فــي مجلــة اللغـــة

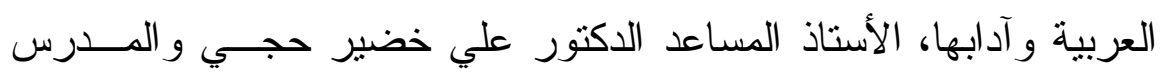
المساعد فلاح رزاق جاسم من جامعة الكوفة. با - أثز أسباب ورود الحديث في فهم السنة، د/بلقاسم حديد،بحث منشور فـي هي هي مجلة (المعيار) العدد. ع ا - أسباب ورود الحديث مفهومه وفو ائده. محمد عبد النبي،جامعــة الجزائـرـ كلية العلوم الإسلامية. 
وو اضح من الدر اسات السابقة تتاولت مسائل بحثنا على وجه العموم، و أما بحثنا تتاولها على وجه الخصوص، و أما الجديد الذي أضافه بحثثا للار اسات الـسابقة ما يلي:

1- تأصيل بأن الأصل في النصوص الحدينية هو عموم اللفظ لا خصوص السبب إلا إذا كان النص يخصصان المعنى أو الفعل.

r- إثبات أن معرفة أسباب ورود الحديث يعتمد على رواية الصحابة الذين عاصروا التتزيل و عايشو ا الوقائع و الأحداث. r- التفريق بين سبب ورود الحديث، وسبب ذكر الحديث. ع- تقرير أن العلم بأسباب ورود الحديث ليس من نافلـــة القــول، بــلـ أن الاهتمام بهذا العلم يقرر الفهم الكلي لمقاصد نتريع السنة النبوية. 0- التأكيد على الفو ائد المنرتبة على معرفة أسباب ورود الحديث لفهم السنة النبوية و الأحكام الفقهية المترتبة على ذلك.

\section{رابعا: خطة البمث:}

وقد رأينا أن نرتب هذا البحث على: مقدمة وتضمنت: أهميــة الموضــوع

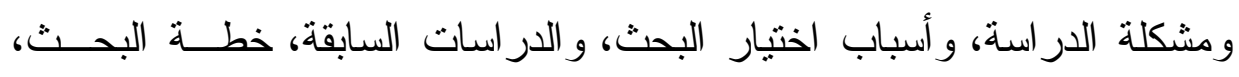
ومنهج البحث، و اشتمل على ثناثة فصول وخاتمة. الفصل الأول: قلة اهتمام الأقدمين بأسباب ورود الحديث. وفيه خمسة مباحث: المبحث الأول: صعوبة إحصاء أسباب الورود.

المبحث الثاني: غياب أهمية أسباب ورود الحديث عند الصحابة. المبحث الثالث: زعم البعض عدم أهمية ورود سبب الحديث. 
المبحث الرابع: اعتبار المصنفين أسباب الورود من ناقلة القول. المبحث الخامس: تأخر ظهور مصنفات ورود الحديث. الفصل الثاني: أهمية معرفة ورود الديث من أجل الفهم الكلي لمقاصد تثريع السنة النبوية. وفيه ثلاثنة مباحث. المبحث الأول: كيفية إدراك هذا العلم.

المبحث الثاني: الفرق بين سبب الورود وسبب الأكر. المبحث الثالث: الفوائد المترتبة على معرفة أسباب الورود. الفصل الثالث: أقسام الأحاديث بالنسبة إلى أسباب الورود.وفيه مباحثان. المبحث الأول: ما له سبب قيل لأجله. وفيه مطلبان. المطلب الأول: النموذج الأول. المطلب الثاني: النموذج الثاني. المبحث الثاني: ما لا سبب له و إنما قيل ابتداء. وأما الخاتمة: فتضمنت ملخص البحث وأهم النتائج والتوصيات وثبت المصادر والمر اجع.

\section{خامسا: مشكاية الدراسة:}

تتلخص مشكلة الدر اسة في أن كثثر ا من الباحثين و الأصوليين يغيب عــنهم

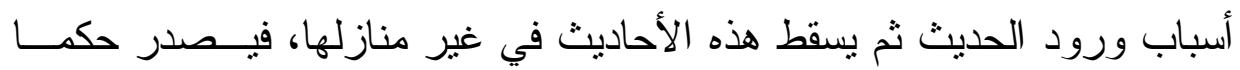

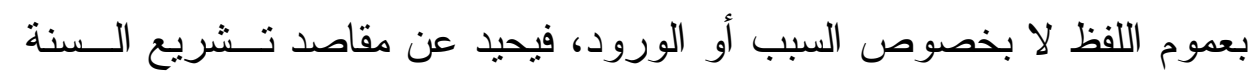
النبوية، كما اختلط على البعض بين سبب ورود الحديث، وسب ذكر الحـديث، فيأتي هذا البحث بهذه الدراسة الحديثة لينبه على تلك المقاصد حتى يكون الحكم 
منو اققا مع نتريع ديننا الحنيف، مع ذكر بعض النماذج النطبيقية لرفع الإشــكال في فهم السنة النبوية ومقاصدها.

\section{سادسا: منهفه البمث.}

سلكنا في هذا البحث المنهج الاستقر ائي الموضو عي وفقا للطريقة الآتية: 1- استخلصنا مفهوم علم أسباب ورود الحديث من المصادر الأصلية مــع توثيق المادة العلمية.

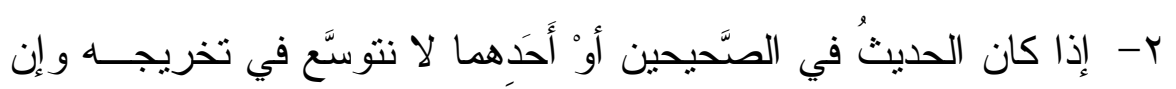

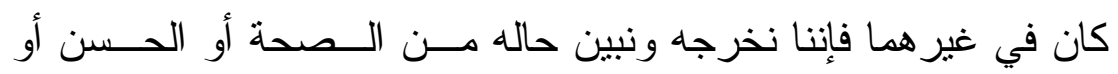

\section{الضعف..}

r- اكتقينا بعزو أحاديث البحث من الكتب التسعة المشهورة، فإذا عز ذلك

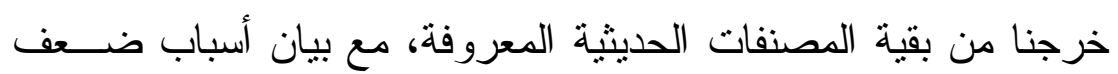
الاهتمام بأسباب ورود الحديث، و أهميته في فهم مقاصد السنة النبوية. ع- حررنا الفرق بين أسباب ورود الحديث، وسبب ذكر الحديث، وأوضحنا أقسامه بالنسبة إلى ورود الحديث، وفو ائد البحث لمعرفة أسبابه. ه - عملنا فهارس علمية للمصادر و المر اجع ليسهل للقارئ الوصول إلى بغيته بأسر ع وقت و أقصر طريق.

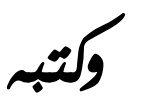

\section{د. هممد يوسف الشطي \\ د. إبراهيم هممد المناوي

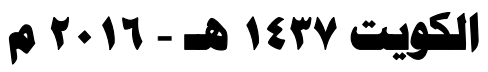




\section{الفمل الأول}

\section{قالة اهتمام الأقدمين بأسباب ورود المديث}

يحسن بنا أن نعرف هذا العلم قبل الثروع في البحــث، فعـرف العلمـــاء

$$
\text { علم أسباب ورود الحديث: }
$$

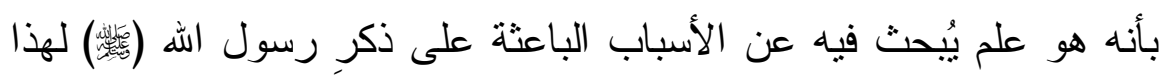
الحديث ابتداءً، وهذا السبب قد يكون سؤالاً، وقد يكون حادثة، وقد يكون قصة، لئه

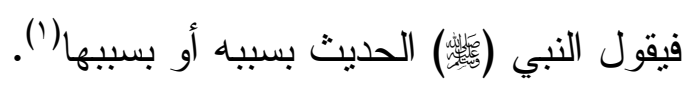

لقد وجد الاهتمام بأسباب النزول منذ بدايات تاريخ التشريع الإسلامي مــن

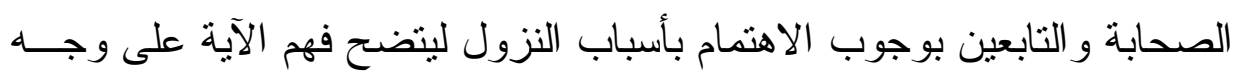
الصحيح، وجاء تتبيه المفسرون و الأصوليون إلى أهمية معرفة المجتهد لأسباب نزول الآيات.

فالسؤ ال إذا ما هي الأسباب التي جعلت معظـــــ الأصـــــليين و المحـــثنين

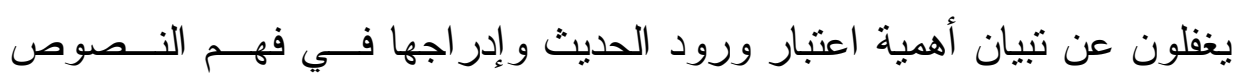

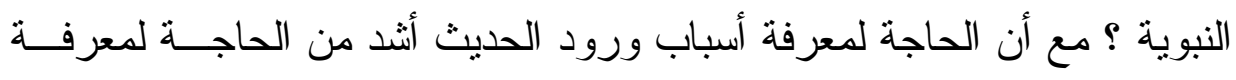

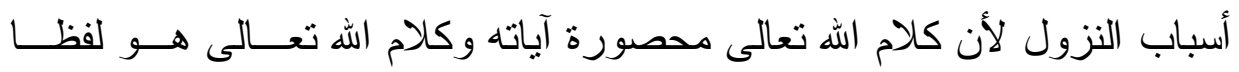

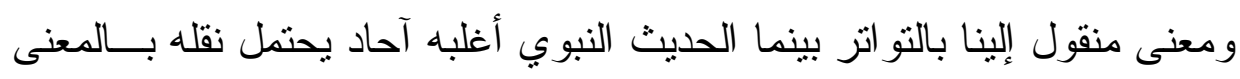

(1) البيان و التعريف في أسباب ورود الحديث الثريف // ب، إبر اهيم بن محمد بن محمد كمال الدين

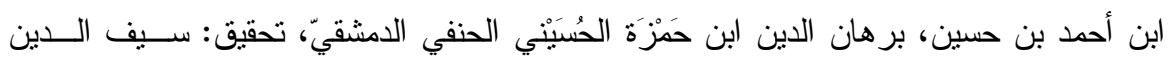
الكانب، دار الكتاب العربي - بيروت. 
للنص النبوي، فعلى سبيل التمثيل نجد أن إمام الحرمين الجويني والآمدي(') قد اشتترطا إلمام المجتهد بأسباب نزول القرآن، ونجد-أيضـا- في مصنفات علــوم

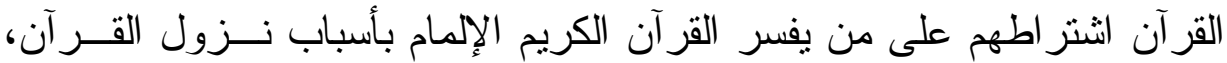
جاء في "البرهان في علوم القرآن" التقسير : علم يعرف به فهم كتاب اله المنزل على نبيه محمد (ئس

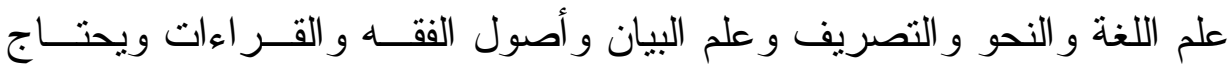

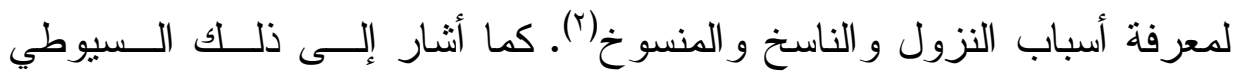
و الزرقاني (). ولم يكتفو ا بالتنظير بل أدرجو ا عمليا أسباب النــزول فـي كتـبـ التفسير ليجدها المجتهذ نصب عينيه فيعتبر ها عند استتباط الآيات. فقلة من الأصوليين من أثنار إلى أهمية اعتبار أسباب ورود الحديث مـنهمج

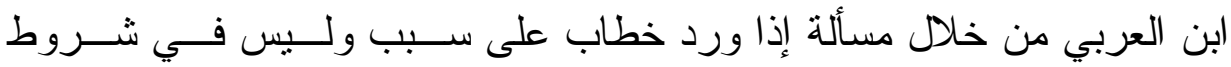
الاجتهاد قال "اختلف الناس فيه فمنهم من قال يقصره عليه و لا يتعجل به غيره،

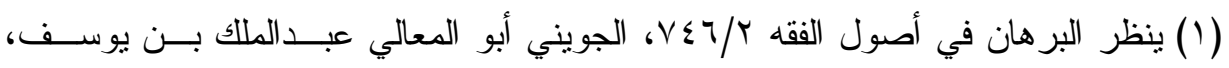
تحقيق: د/ صلاح عويضة، المنصورة دار الوفاء طع، و الإحكام في أصــول الأحكــام

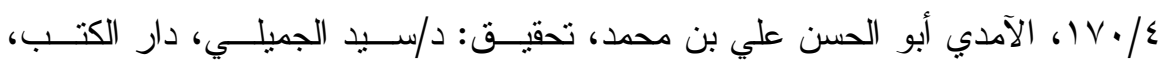

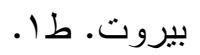

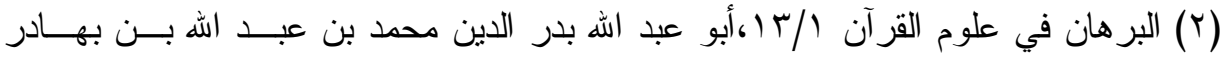

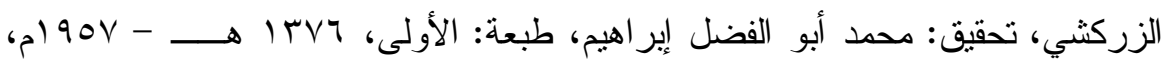
دار إحباء الكتب العربية عيسى البابى الحلبي وشركائه.

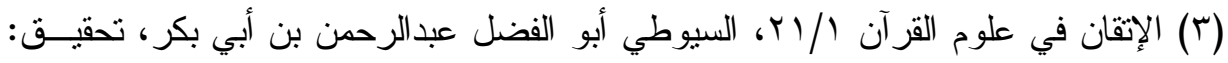

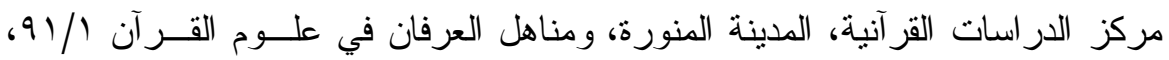

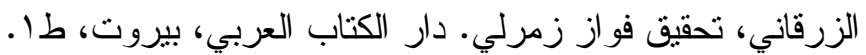


وقال بعضهم يحمل اللفظ على عمومه من غير اعتبار بالسبب، وقــال علماؤنـــا الذي يقتضيه مذهب مالك أن الألفاظ الو اردة على الأسباب على ضربين: الأول: أن يكون اللفظ مستقلا بنفسه لا يحتاج إلى معرفة المر اد منـــه إلــى

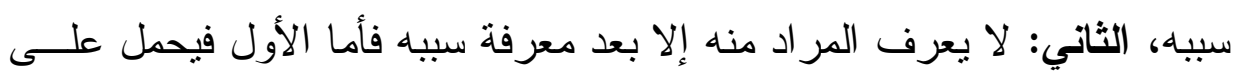

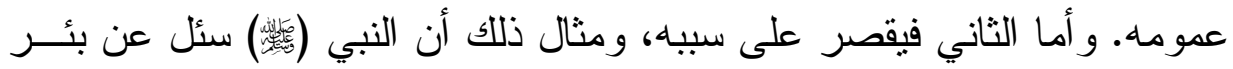

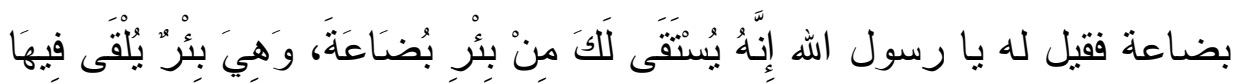

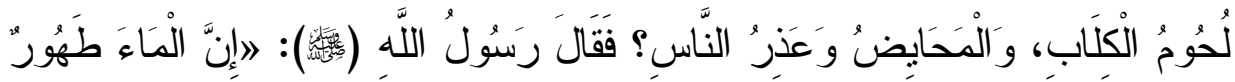

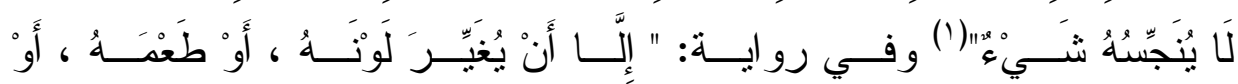

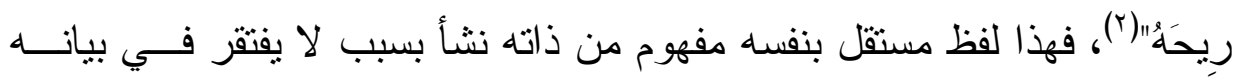

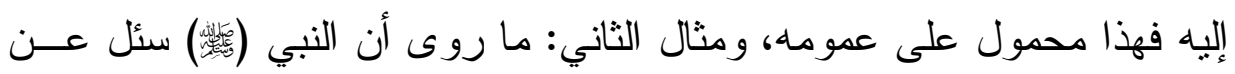

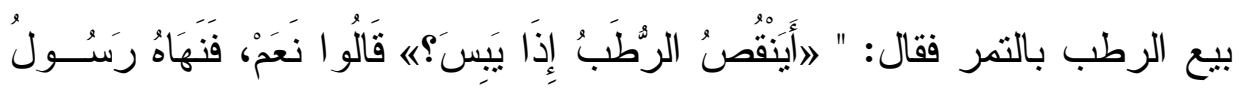

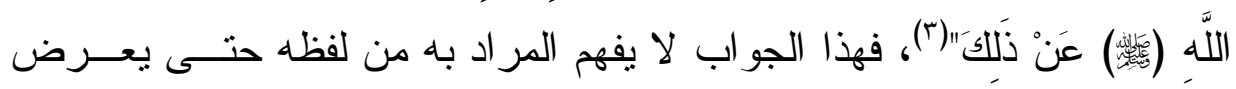

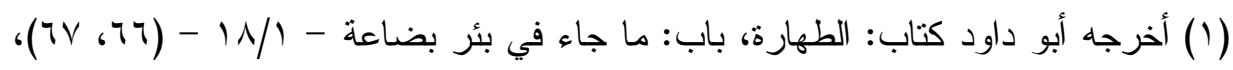

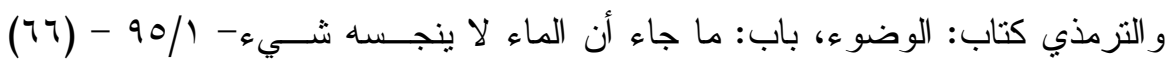

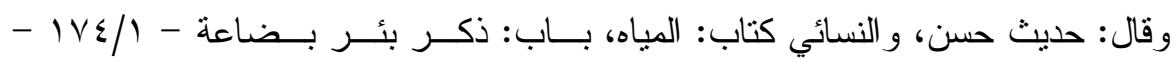

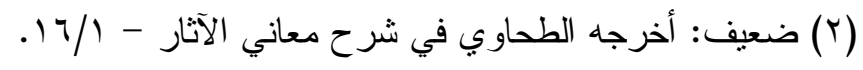

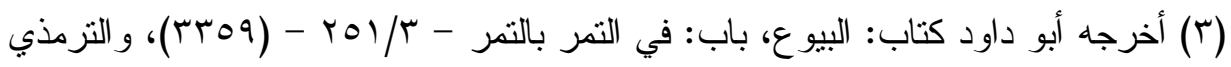

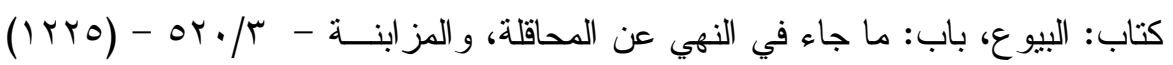

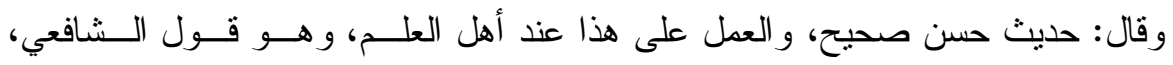

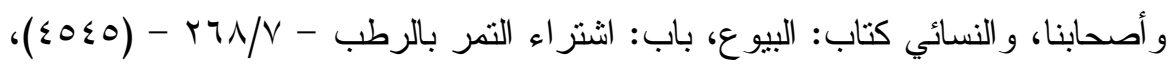

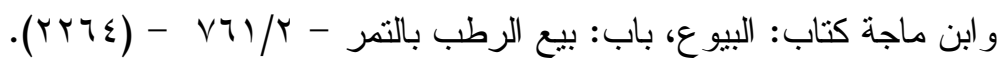




\section{الدكتور / محمد يوسف الشطي و الدكتور / إبراهيم محمد محمد عبد العال الحناوي}

على سببه ويناط به('). و أثنار الإمام السبكي إلى أهمية اعتبــار أسـباب ورود

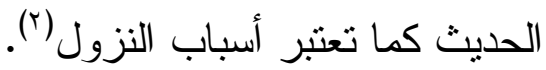

أضف لذلك أن كتب الصحاح و السنن لم تولي اهتماما عمليا بأســباب ورود

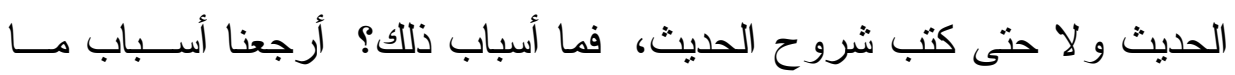
ذكر إلى خمسة أسباب، جعلناها على خمسة مباحث.

(1) أصول في أصول الفقه: (19/، ابن العربي، أبو بكر المعافري المالكي، تحقيق: حسين

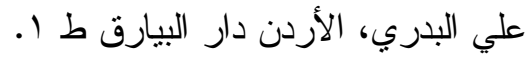

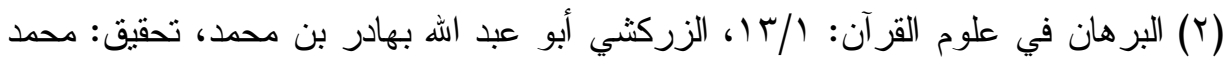

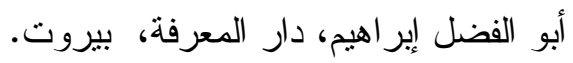




\section{المبحث الأول}

\section{صعوبة إصماء أسباب الورود.}

صعوبة إحصاء أسباب ورود الحديث النبوي بخلاف القر آن الكــــيم فــان آياته محصورة ومتواترة لجميع الأمة. فهذا يقرره قول الصحابي الجليل عبد الله

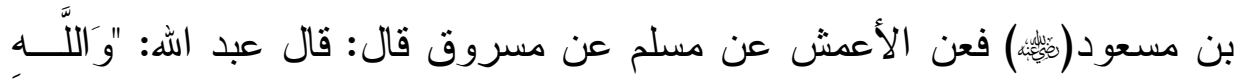

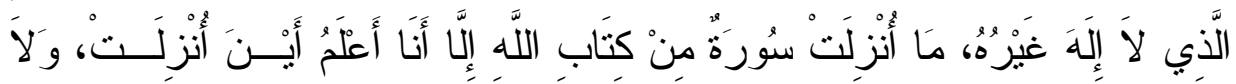

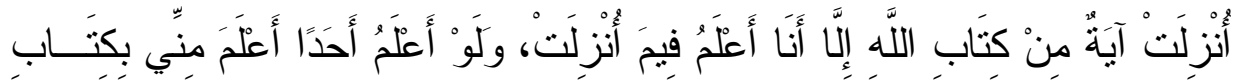

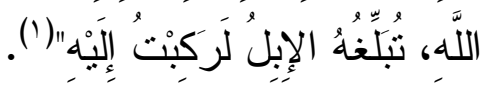

فهذا دليل على إحاطة بعض الصحابة بجميع أسباب النزول بخــاف ورود

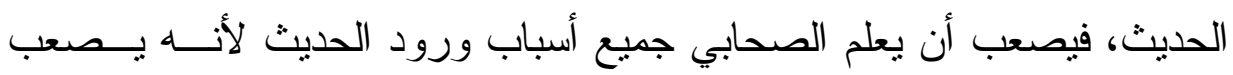

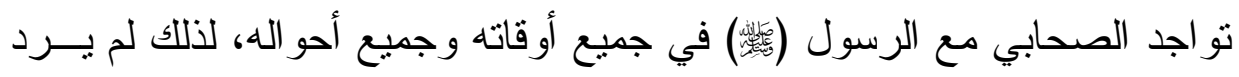
عن أي صحابي علمه بأسباب ورود الحديث.

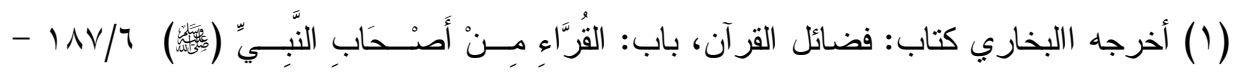

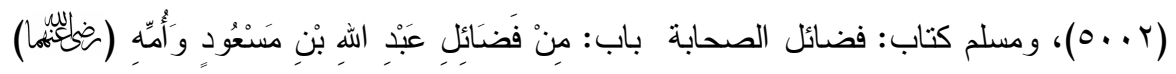
$(T \leq 7 T)-191 T / \varepsilon$ 


\section{المبحث|ثاني}

\section{غياب أهمية أسباب ورود الهديث عند الصحابة}

عدم تتبيه الرعيل الأول وهم من أنزل عليهم التنزيل إلى أهميــة اعتبــار

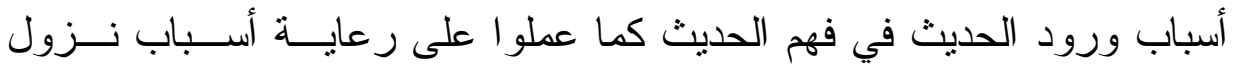

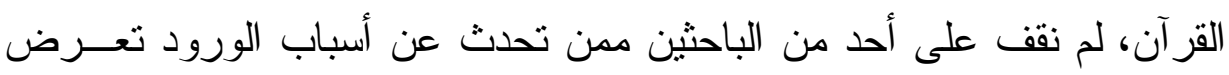

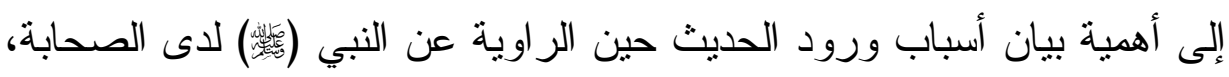

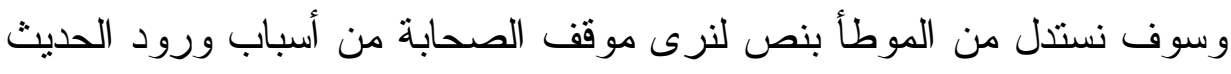

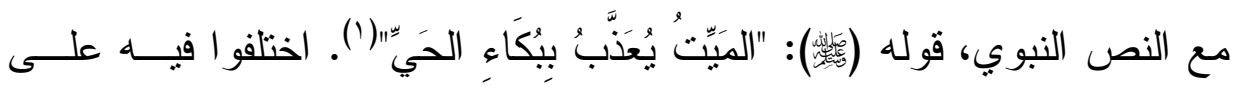

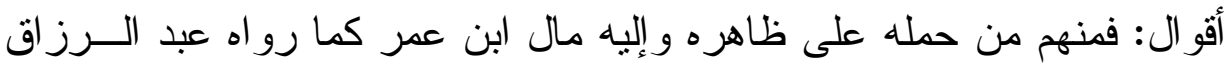

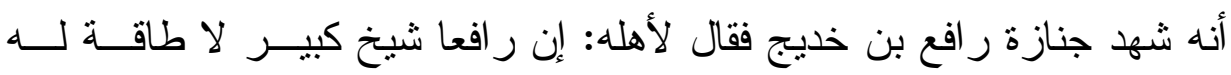

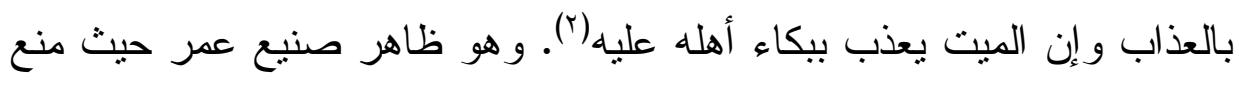

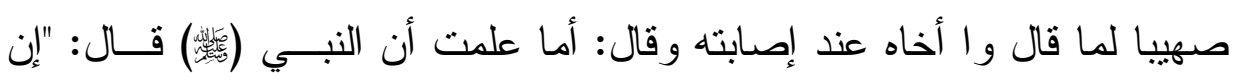

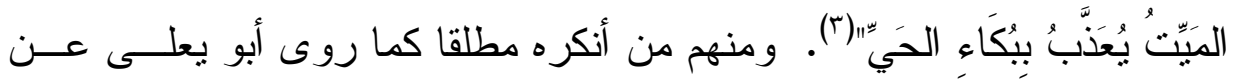

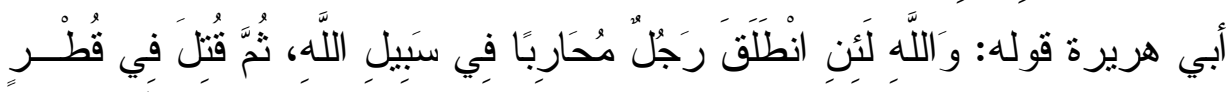

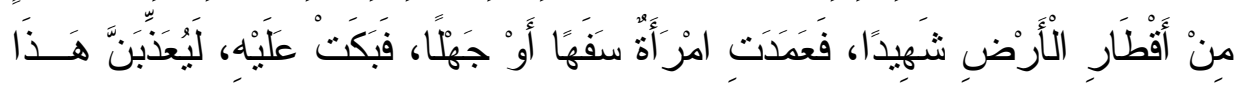

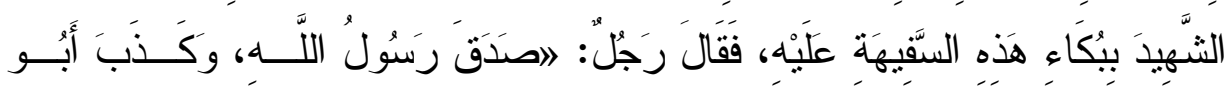

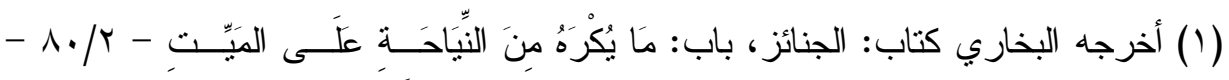

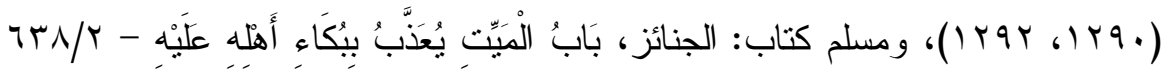

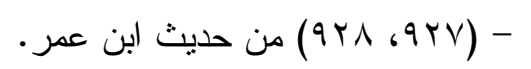

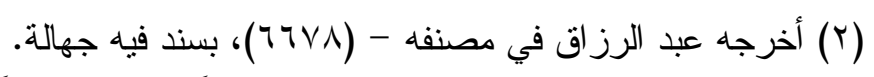

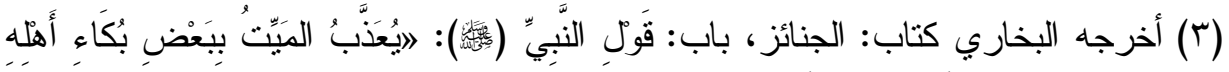

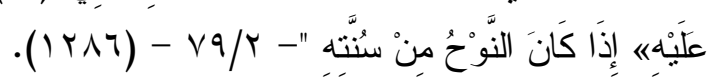




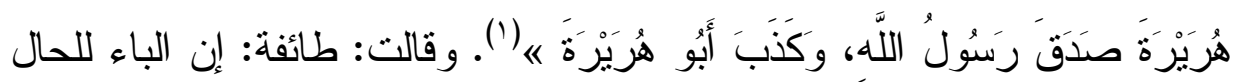

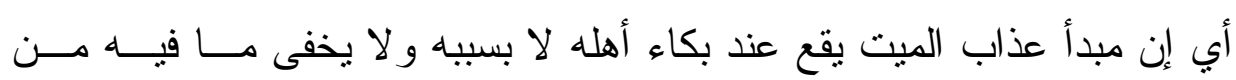
التكلف، وقال جمع: إن الحديث ورد في معهود معين كما تدل عليــهـ روايـــة عمرة عن عائشة (r). وقال جمع: إنه مختص بالكافر لرواية ابن عباس عن عائشة عند البخاري

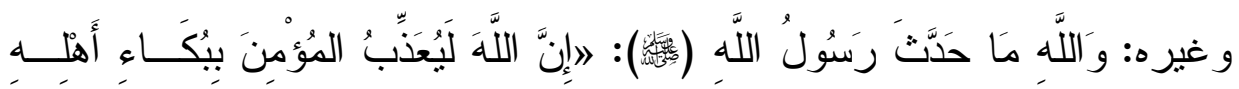

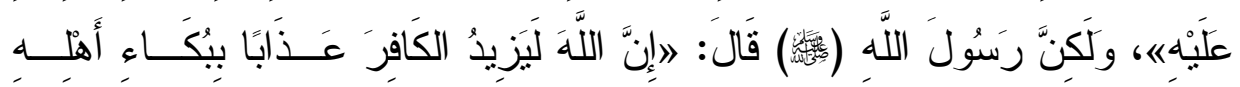

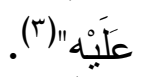

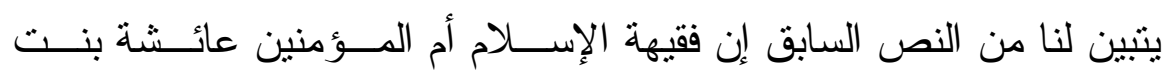
الصديق (مفاكمّا) رأت أن سبب ورود الحديث في يهودية مخصص وليس عـام

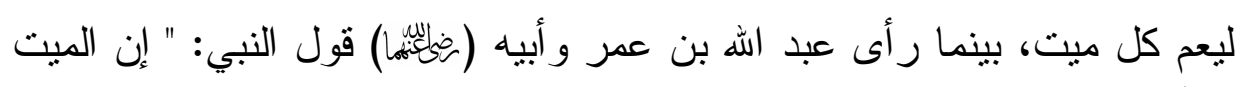

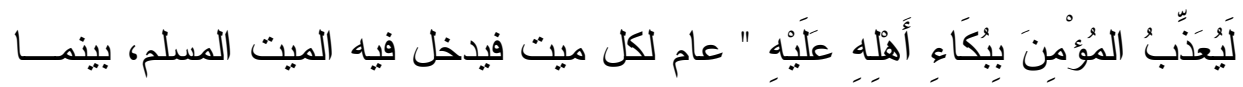

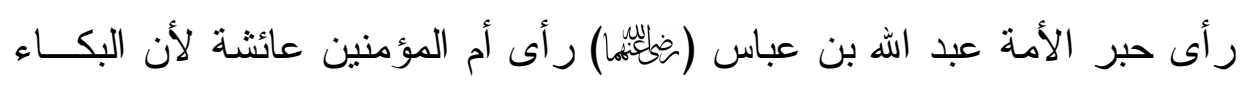
و الضحك ليسا تحت قدرة العبد، فالسيدة عائشة توجب على راوي الحـديث ألا يقتصر الر اوي على النص النبوي بل يتبعه بسبب وروده، لأن اقتصار الــراوي

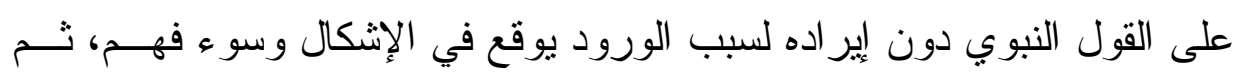

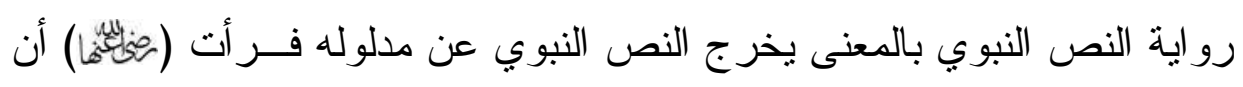

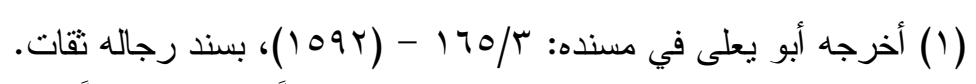

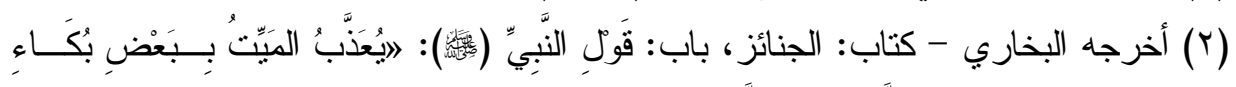

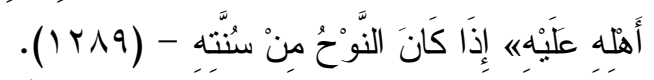

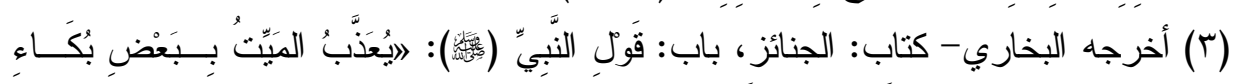

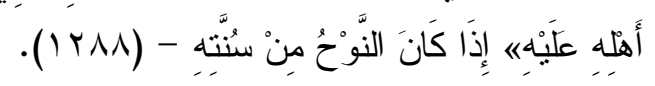


عبد الله بن عمر لم يكذب على النبي (敬) ولكن طريقة أدائه للحــديث النبــوي

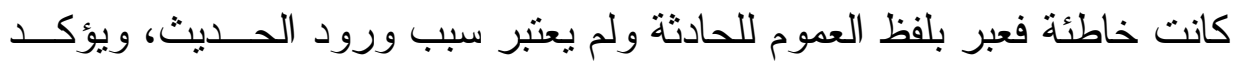
هذا المعنى بوضوح أكثز ما جاء في الموطأ عن عمرة بنت عبد الرحمن أنهــا

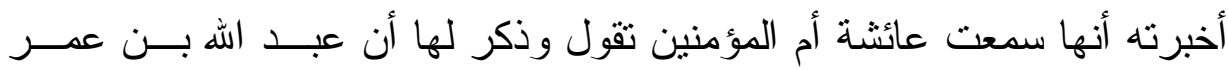

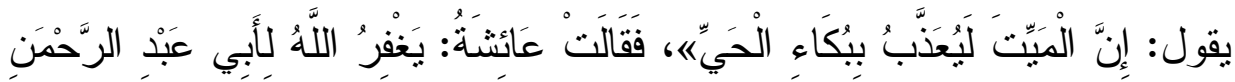

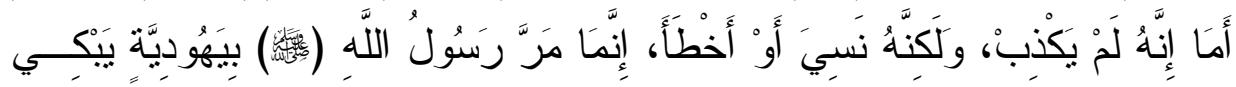

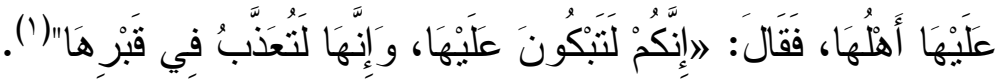
ومسلك أم المؤمنين عائشة في وجوب ذكر سبب ورود الحديث لم يقتــر

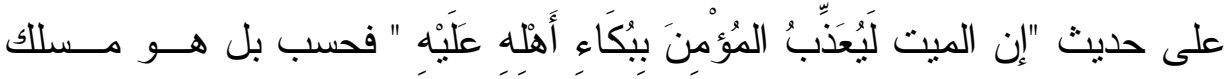

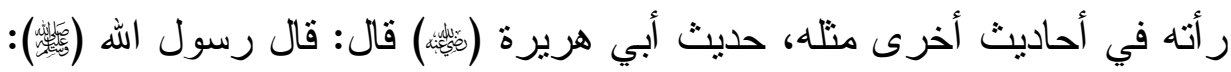

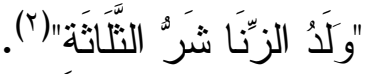

فأنكرت أم المؤمنين عائشة رواية أبي هريــرة دون ذكــر ســبب ورود

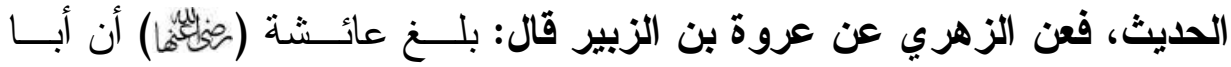

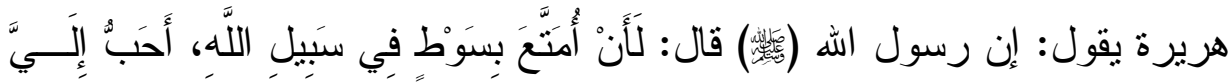

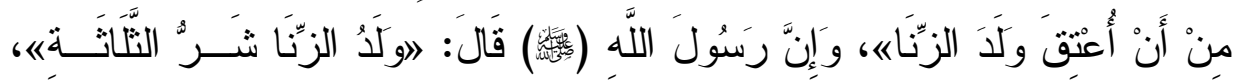

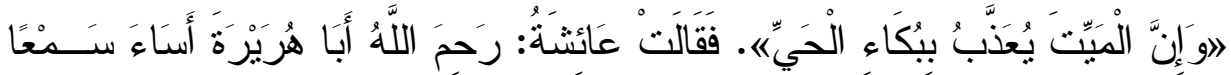

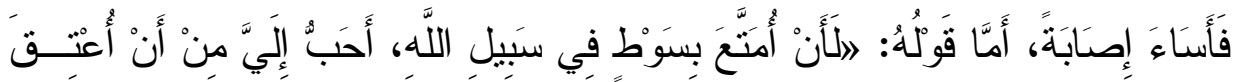

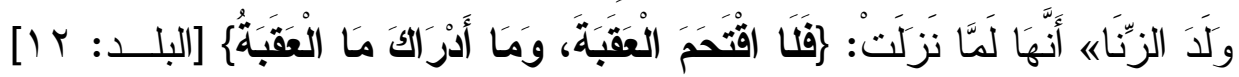

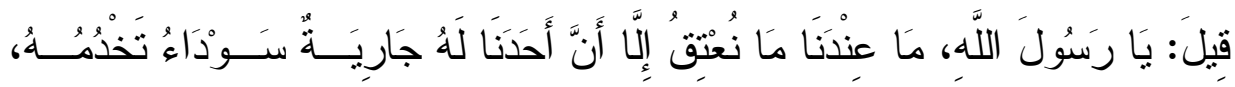

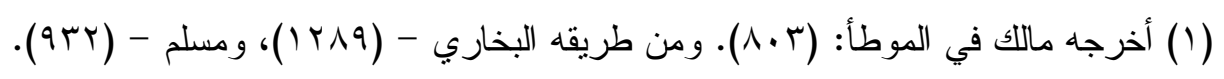

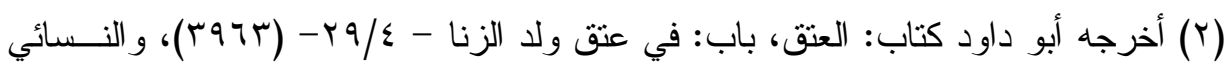

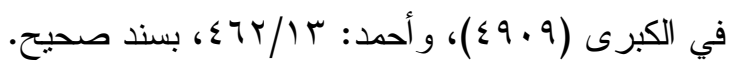




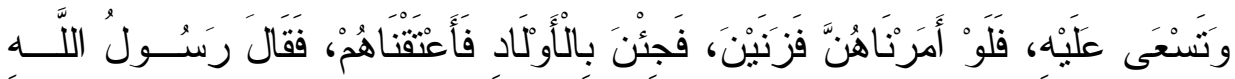

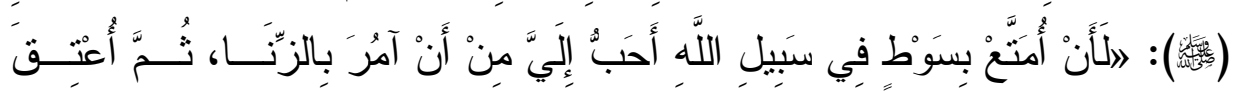
الَْوََََ.

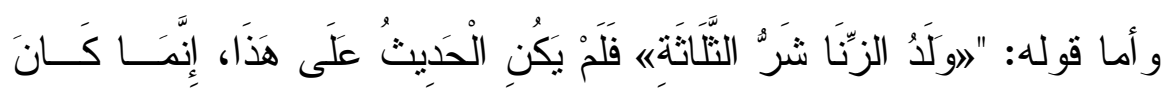

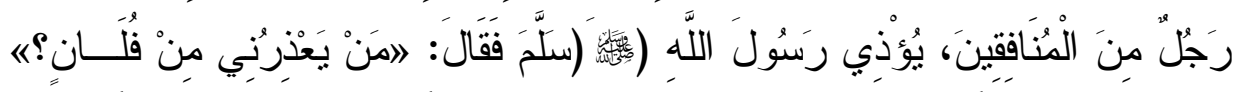

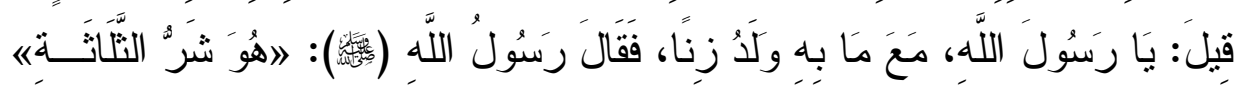

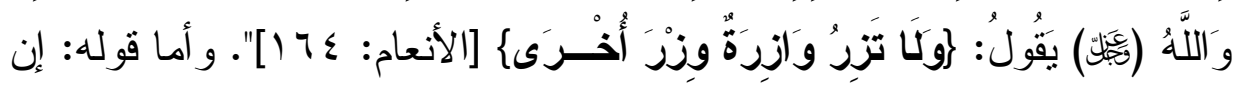

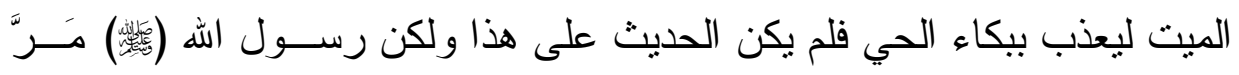

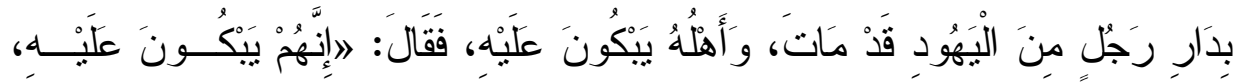

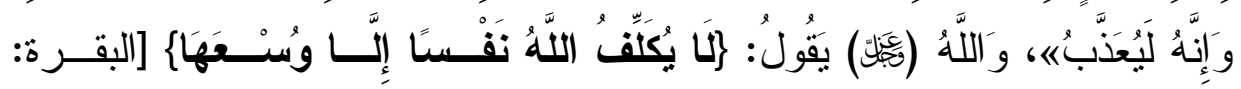
(')" [YNT

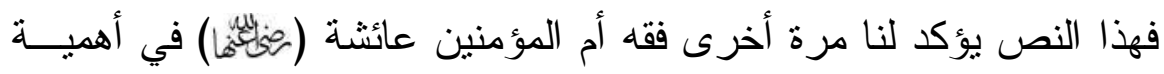

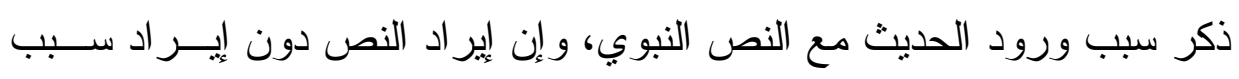

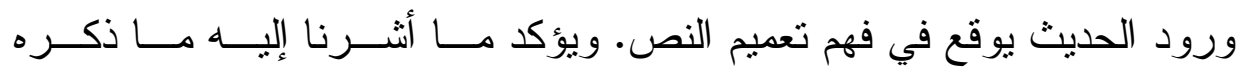

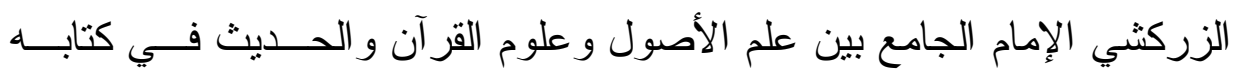

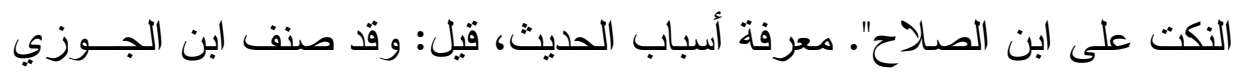

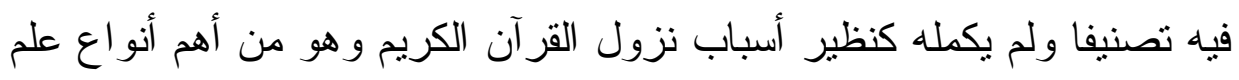

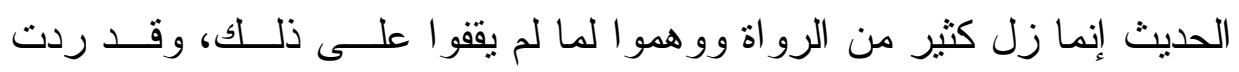

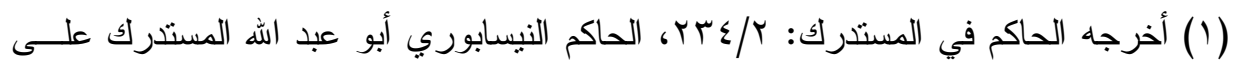

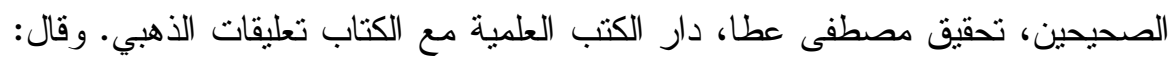

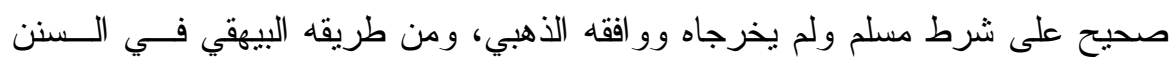

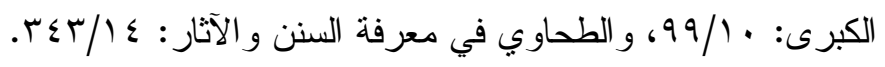




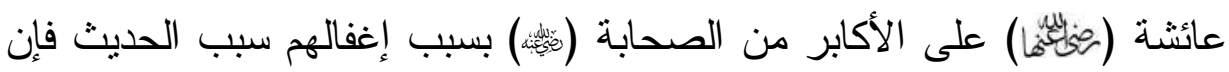
قيل: أي فائدة لهذا النوع من أن العبرة بعموم اللفظ لا بخصوص السبب؟ قيـلـل فائدته عدم تخصيص محل السبب أو فهم المعنى من السياق كما في حديث "ورَكَّ

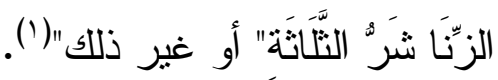

فالإمام العلامة الزركشي الأبي جمع بين علم أصول الفقه وعلوم القــــآن والحديث: يرى إن العلم بأسباب ورود الحديث من أهم علوم الحديث و إن السيدة عائشة أم المؤمنين كانت ترد الأحاديث على أكابر الــصحابة بــسبب إغفــالهم لسبب ورود الحديث، ثم رد دعوى من لم يرى فائدة بذكر سبب ورود الحديث لأن القاعدة تقول "العبرة بعموم اللفظ لا بخصوص السبب" مما يتطلــبـ تعــديلا في القاعدة، وهو ما سنبينه في المبحث الثالث. فنخلص مما سبق أن الصحابة كرضوان الله عليهم - قد وقفو ا من مـسألة وجوب إلحاق سبب الورود الحديث مع النص النبوي على اتجـــاهين: اتجـــاه أم المؤمنين عائشة ويتبعها ابن عباس وجوب إير اد سبب ورود الحديث، إذا كـــان عدم إير اده يورد في إثكالية فهم النص النبوي فهما صحيحا.

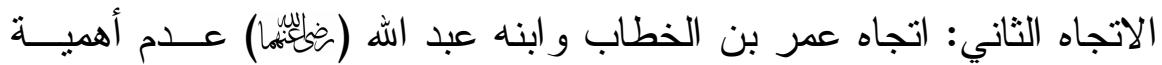

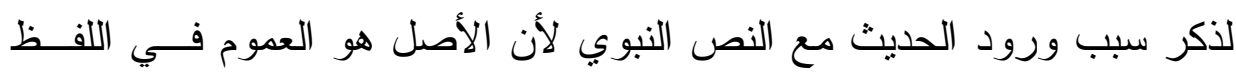
النبوي، وكأنه يشير أن علم أسباب ورود الحديث لم يكتمل تصنيفه فهــذا فـي هي عصره، ولكنه في العصور المتأخرة قد اكتمل أكثره.

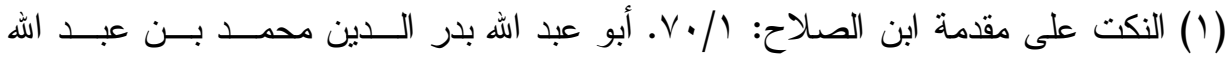

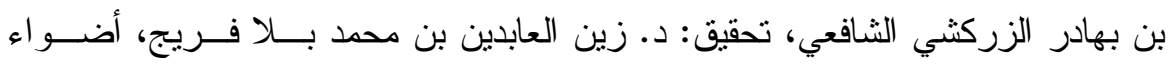

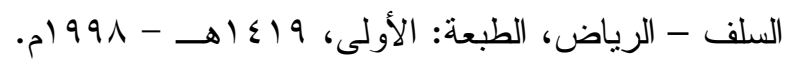




\section{المبحث الثالث:}

\section{زعم البعض عدم أهمية ورود سبب المديث}

هذا المبحث له تعلق بأسباب النزول و أسباب ورود الحديث و إن كان تعلقــهـ في جانب أسباب ورود الحديث أكثر لصعوبة معرفة ورود الحديث عن معرفــة أسباب النزول. هذا المبحث بني على مسلك من يرى أنه لا فائدة استتباطية من

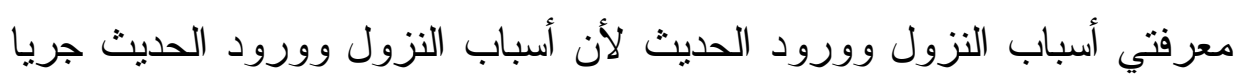
مجرى التاريخ. يرد على مسلك هؤلاء الإمام السيوطي فقال: "زعم ز اعم أنه لا لابن طائل تحت هذا الفن لجريانه مجرى التاريخ، و أخطأ في ذلك بل لله فو ائد منها: 1- معرفة وجه الحكمة الباعثة على نشريع الحكم.

ץ- ومنها تخصيص الحكم به عند من يرى أن العبرة بخصوص السبب. ب- ومنها أن اللفظ قد يكون عاما ويقوم الدليل على تخصصه فإذا عـرف السبب قصر التخصيص على ما عدا صورته فإن دخول صورة السبب قطعي و إخر اجها بالاجتهاد ممنوع، كما حكى الإجماع عليه القاضي أبو بكر في التقريب ولا التفات إلى من شذ فجوز ذلك. ع- ومنها الوقوف على المعنى و إز الة الإثكال. قـــال الو احــدي لا بمكـنـ تفسير الآية دون الوقوف على قصنها وبيان نزوله"(').

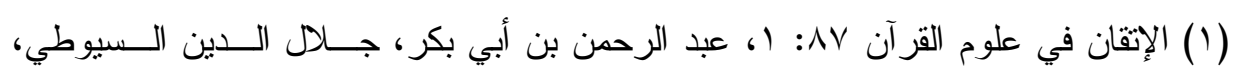

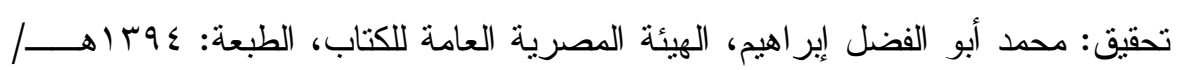
. $19 \vee \leq$ 
وقد يكون من أسباب صرف الاهتمام عن أسباب النزول -بعامــــ-وورود

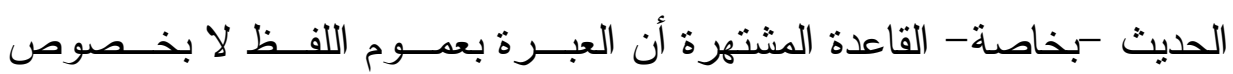

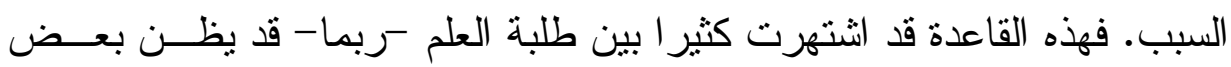
الطلبة أن هذه القاعدة بمثابة إجماع من العلماء وليس هناك خلاف حول التسليم بها، جاء في كتاب القو اعد و الفو ائد الأصولية: "إذا ورد دليل بلفظ عام مسستقبل

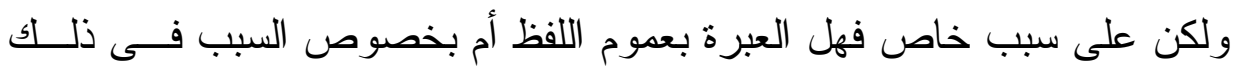
مذهبان:

أحدهما: العبرة بعموم اللفظ وهو قول أحمد و أصحابه و الحنفية ونص عليه

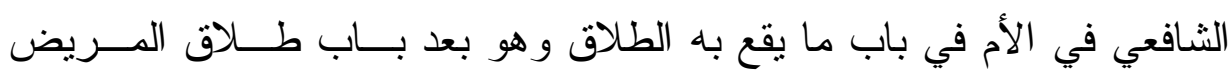
و اختاره الإمام فخر الدين و الآمدى و أنباعهما.

و المذهب الثاني: العبرة بخصوص السبب وذكره أبو العباس روايــة عـن أحمد أخذا مما ذكره الخلال في عمدته و اختاره المزني، و القفال، و الدقاق، وقاله أبو الفرج و ابن نصر و غيرهما من المالكية، وحكاه أبو الطيب، وابن برهان عن مالك و الجوينى وهو الذي صح عندنا من مذهب الثافعى ('). فمما سبق ندرك أن هناك اتجاهان رئيسيان في اعتبار السبب و عدمه: الاتجاه الأول: برى أن العبرة بعدوم اللفظ لا بخصوص السبب. الاتجاه الثاني: العبرة بخصوص السبب لا بعموم اللفظ.

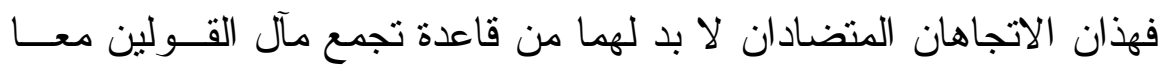
فيضعها المجتهد نصب عينيه في أسباب النزول وأسباب ورود الحديث. وبــاله

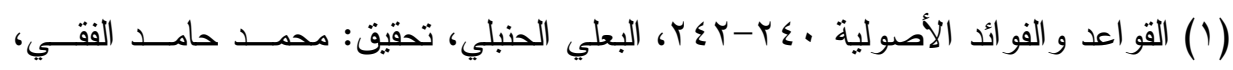
القاهرة. مطبعة السنة النبوية بتصرف. 
نستمد منه العون فنضع قاعدة جامعة مانعة في أسباب النــزول و الــورود. لأن عدم وضـع قاعدة جامعة مانعة تجمع بين مذهبين رئيسين في اعتبــار الــسبب يؤدي إلى إهمال الاتجاه الثاني الذي يعتبر خصوص السبب و لا يقل أهمية عـن لئن

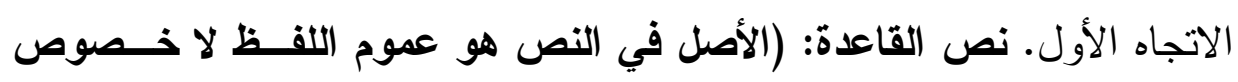
السبب أو الورود إلا إذا كانا يخصصان المعنى أو الفعل). فقد يستدرك مستدرك فيقول كيف خصصت القاعدة ؟ نقول: إن هذه القاعدة ليست على عمومها بمعنى أنه ليس كل نص الأصل فيه هو العموم، ويؤيد ذلك

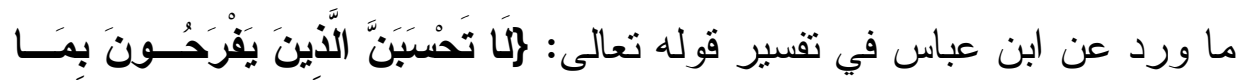

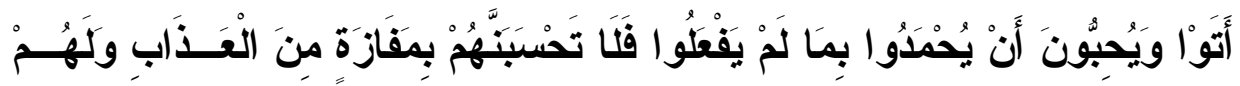

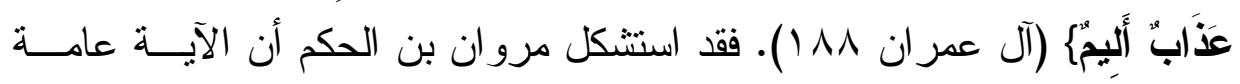
لكل من يحمد بما لم يفعل. فقد روى حميد بن عبد الرحمن بن عوف أخبره أن مروان قال: اذهب يــا

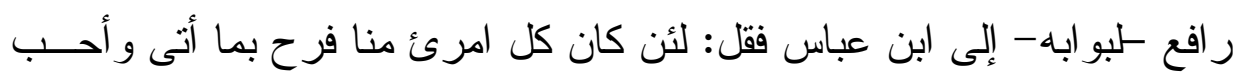
أن يحمد بما لم يفعل معذبا لنعذَبن أجمعون. فقال ابن عباس: وما لكم وهذه إنما

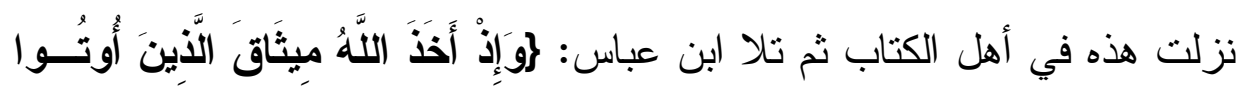

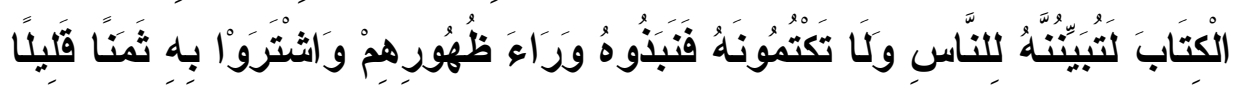

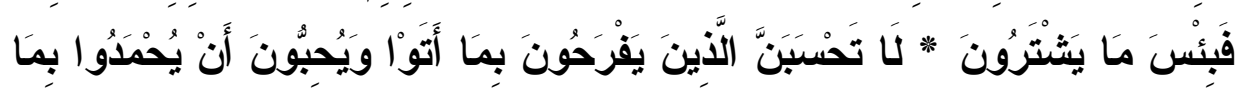

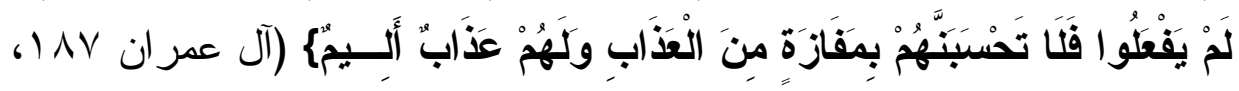

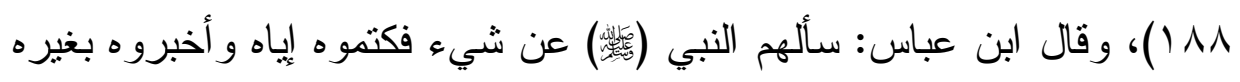
فخرجو ا قد أروه أن قد أخبروه بما سألهم عنه واستحمدو ا بذلك إليه وفرحو ا بما 
أنو ا من كتمانهم ما سألهم عنه(')، بل حتى القرطبي في تفسيره رأى أن عمــوم

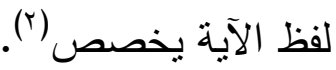

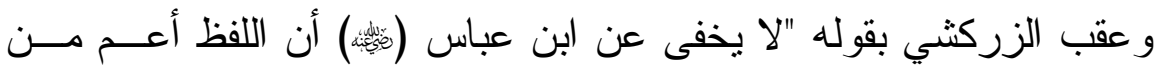

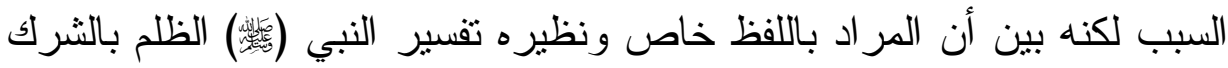
"(r)، ثم يزيد نوضيحا لذلك النوع من أسباب النزول فقال: ومن ذلك قوله تعالى:

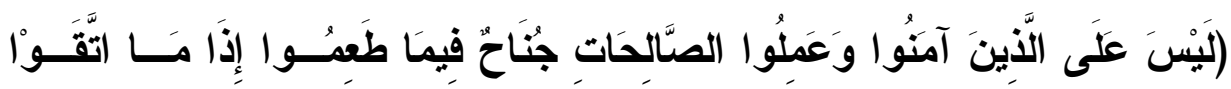

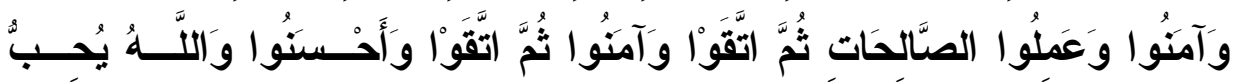
الُْحسنِنِنَ...) (المائدة: بوه). فحكي عن قدامة بن مظعون أنه كان يقول الخمر مباحة ويحتج بهذه الآية وخفي عليه سبب نزولها فعن الزهري قــال: أخبرنـي

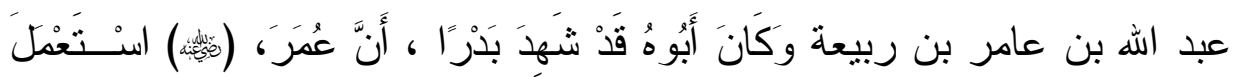

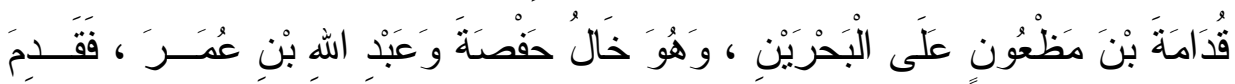

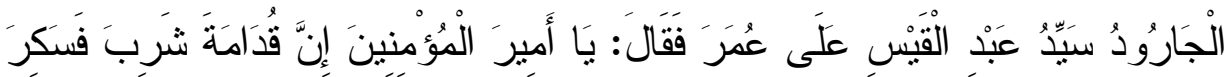

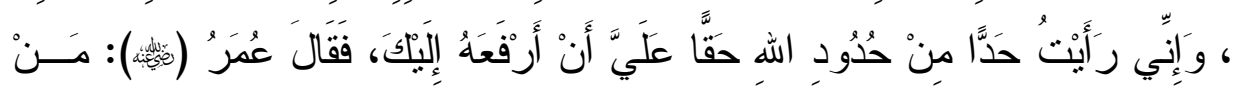

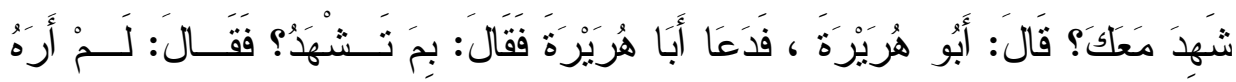

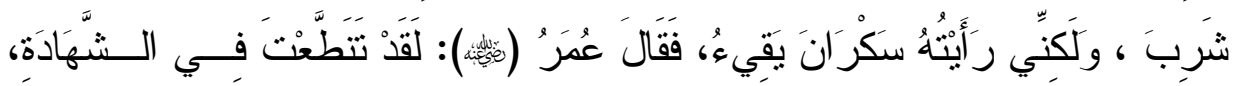

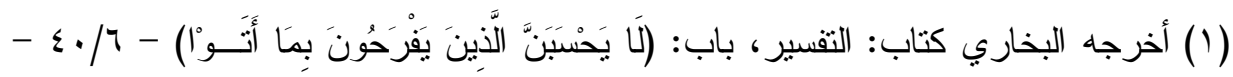

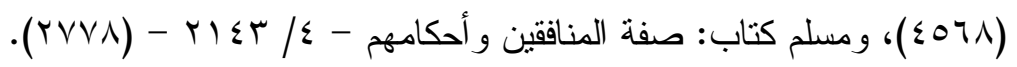

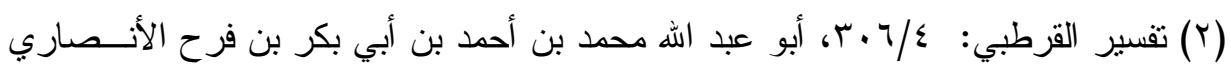

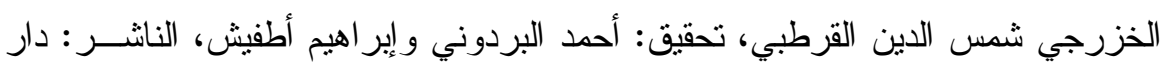

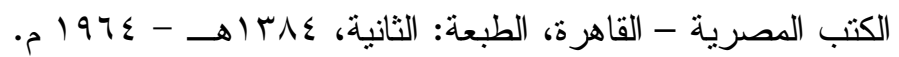

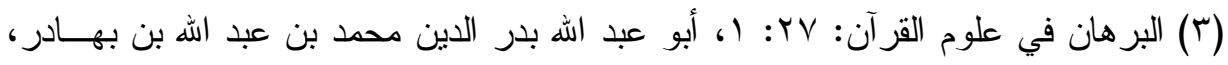

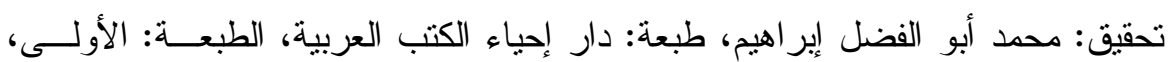

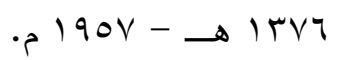




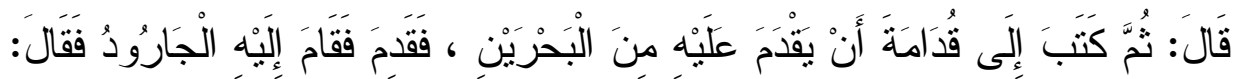

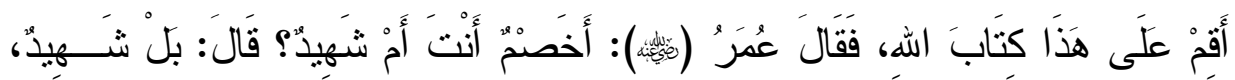

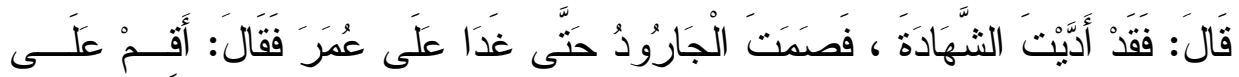

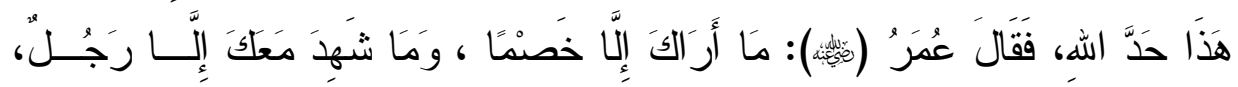

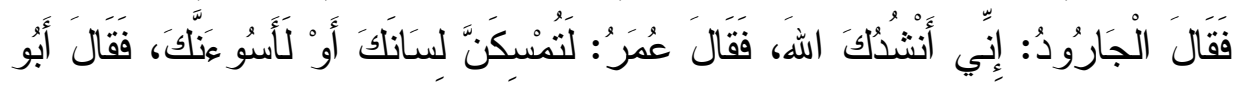

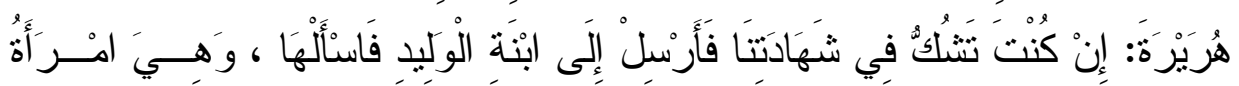

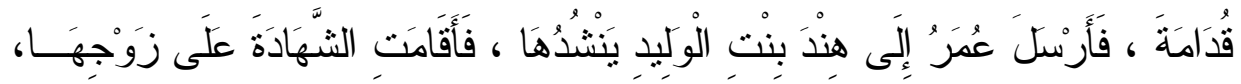

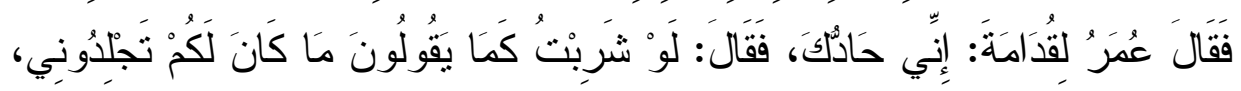

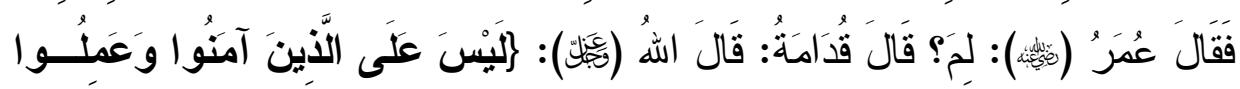

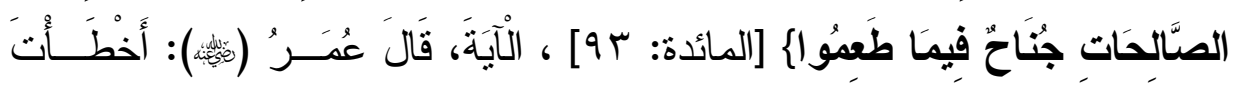

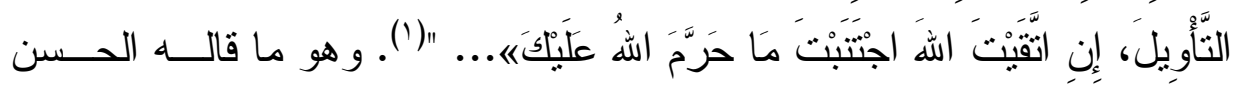

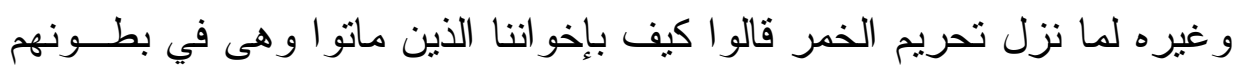

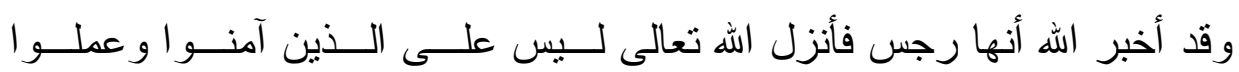

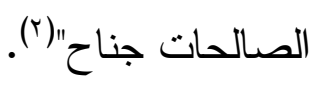

فنخلص مما سبق إن قاعدة العبرة بعموم اللفظ لا بخصوص السبب لــيس على إطلاقها في جميع النصوص الشرعية بل لابد من قيد لها لكي تطرد هــذه

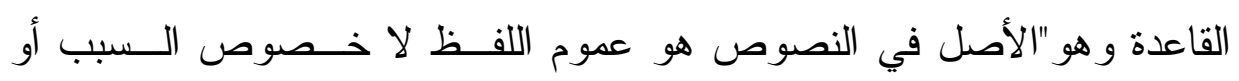
الورود إلا إذا كانا يخصصنان المعنى أو الفعل".

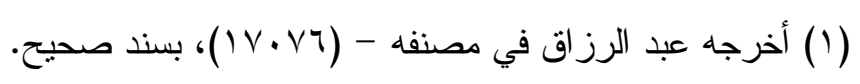

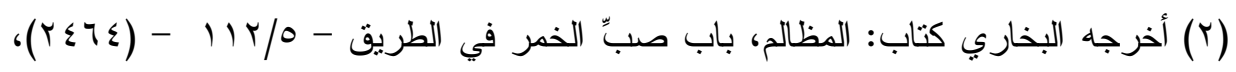

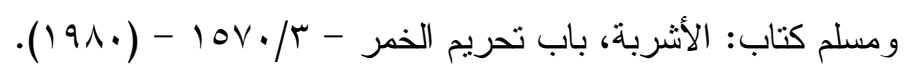




\section{المبحث الرابع}

\section{اعتبار المنفين أسباب ورود المديث من نافلة القول}

إن أصحاب الجو امع و المصنفات الحديثية (لصهم) كان همهم منصب علـى

نقل اللفظ النبوي الثريف دون الاهتمام بأسباب ورود الحديث التـي قــد تـأتي

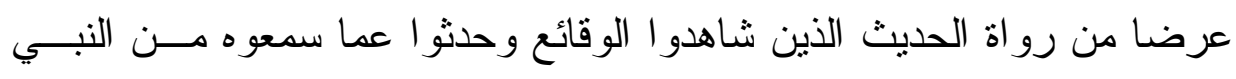

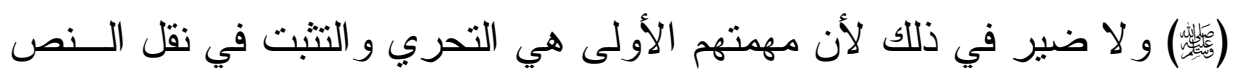

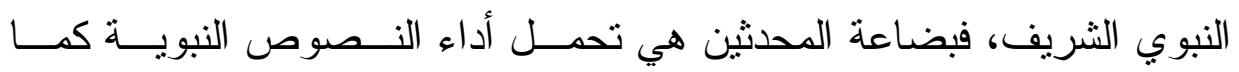

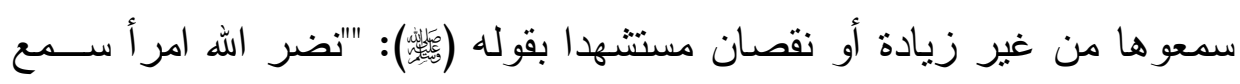
مقالتي..."(') فالنص ربط تحمل للفظ، أما ما يتعلق بنقل أسباب ورود الحـديث فقد ير اه الر اوي أنه من نافلة القول.

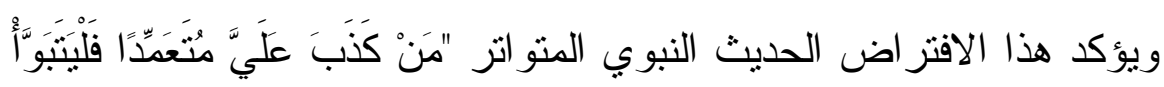

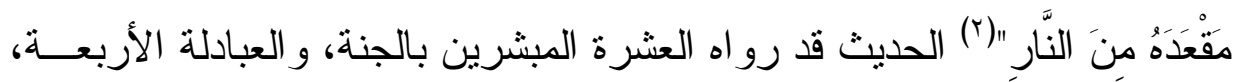
و عمار بن ياسر ، وأسامة بن زيد، و أبو هريرة، و أبو موسى الأشعري، و الكثيــر

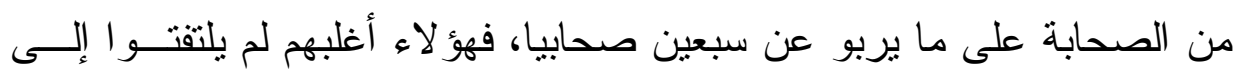
سبب ورود الحديث في رواياتهم لأنه عندهم من نافلة الراوية.

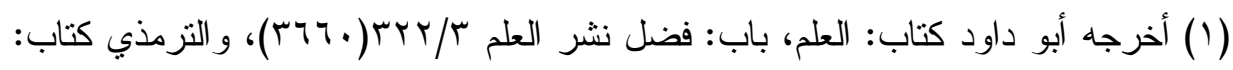

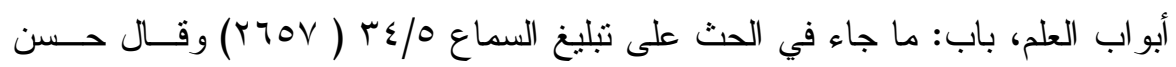

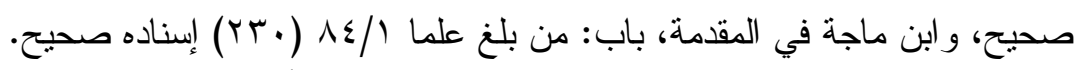

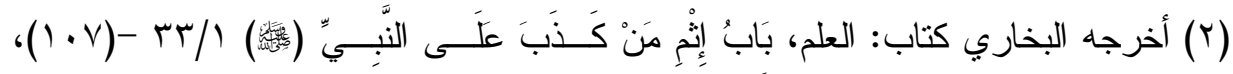

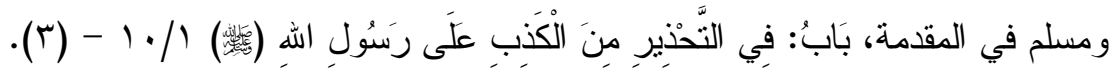


وسبب ورود الحديث وجدناه عند الطبر اني عن عبد الله بن عمرو أَنَّ رَجِلًا لَبِسَ

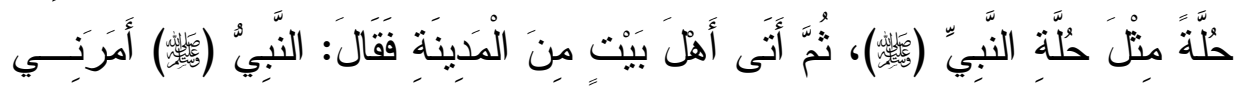

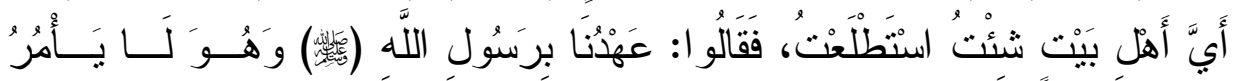

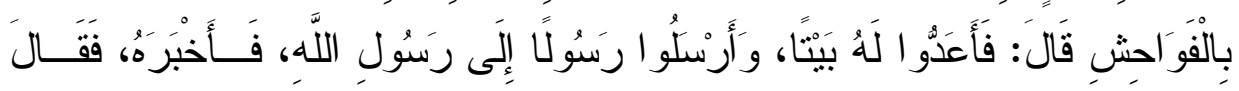

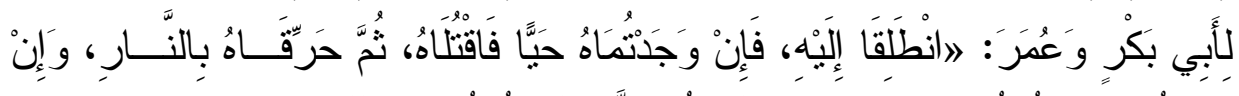

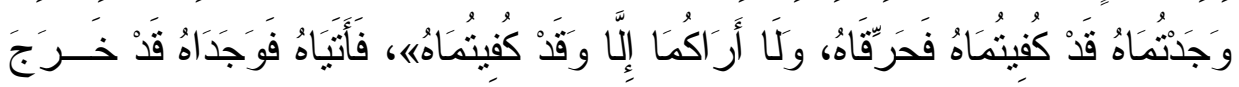

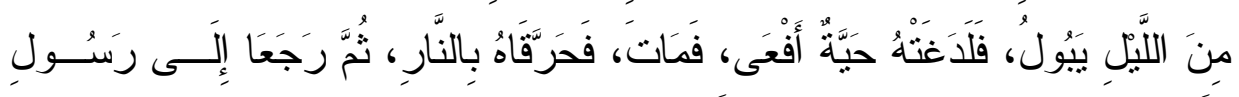

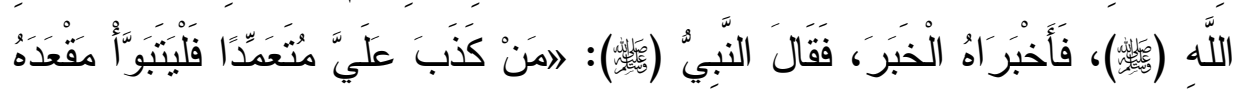
مِنَ النَّارِ" "( (1).

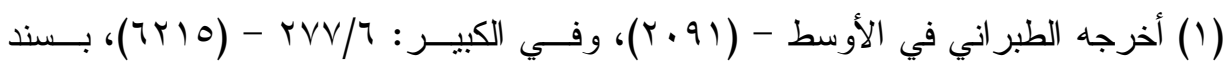

$$
\begin{aligned}
& \text { حسن. }
\end{aligned}
$$




\section{المبحث|لخامس}

\section{تأفر ظهور هصنفات ورود سبب المديث}

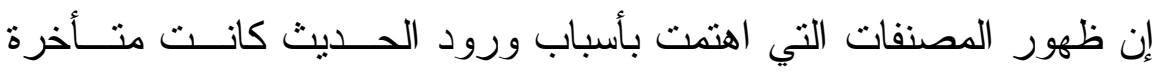
وكان معظمها مفقود غير متداول بين فقهاء الأمة منها: مصنف أبــي حفـص العكبري المتوفى سنة وqب هجرية، ومن المصنفات المفقودة في أسـبـاب ورود مهاء الحديث مصنف لعبد الرحمن بن نجم المعروف بابن الحنبلــي المتـوفى عاب هجرية، فهذا يعني أن التفات معظم الفقهاء إلى أسـبـاب ورود الحــديث كـــان متأخر ا في أفضل عصور تدوين الفقه. و لا يهم كتيــرا اتـدوين أسـباب ورود الحديث إذ لم يكن في التطبيق الفقهي منه فائدة نعني إذا لم تدرج أســباب ورود

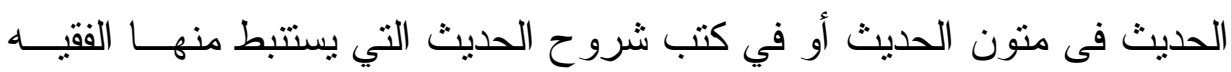

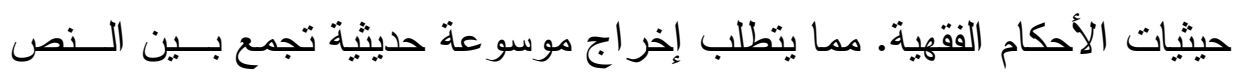

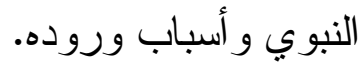




\section{النمصل الثمانبي}

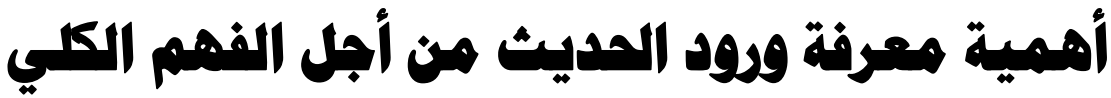

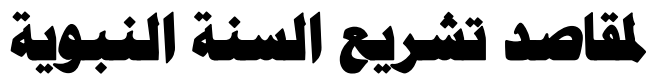

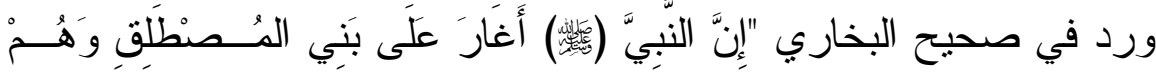

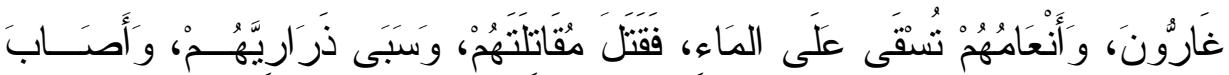

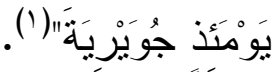

فالحديث السابق لو أخذ فيه فعل النبي (瀻) على إطلاقه دون اعتبار لسبب ورود الحديث لعارض كثير ا من الأحاديث النبوية التي وصفت فعل النبي قبـلـل القتال.

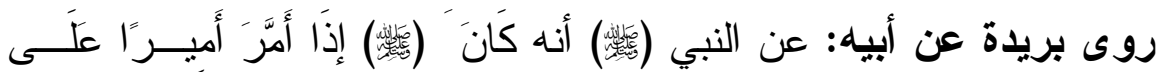

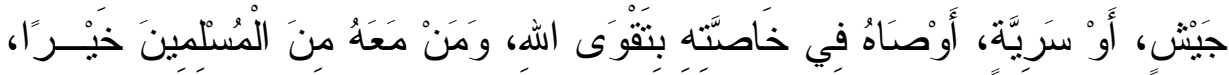

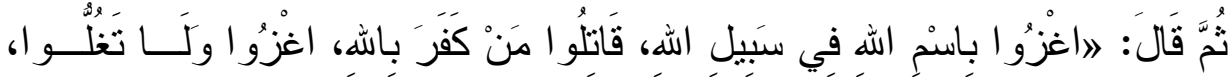

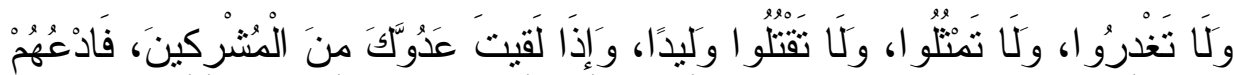

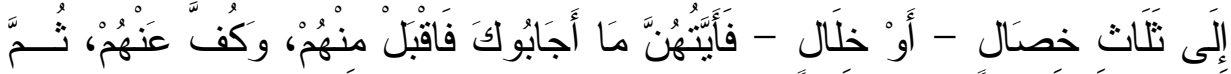

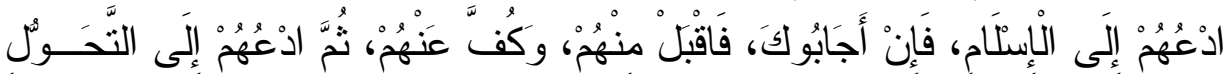

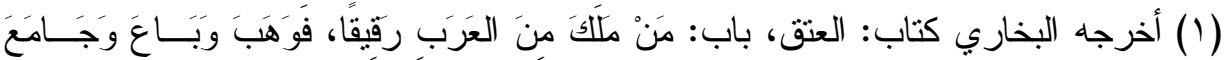

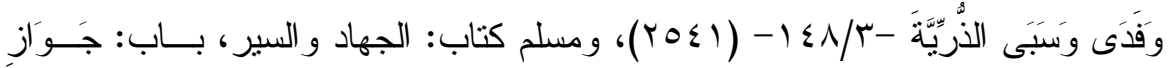

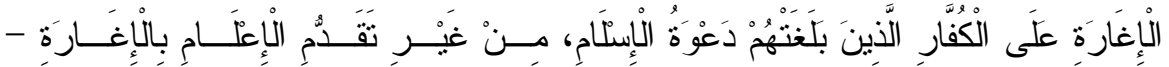

$$
\text { . (IVT. ) - I I r }
$$




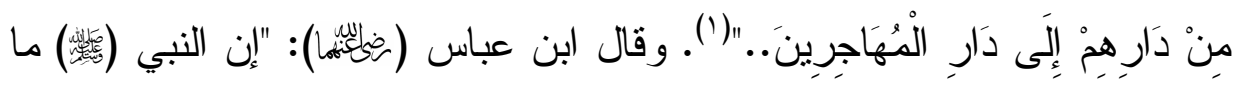

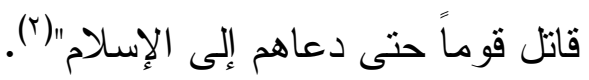

فلفظا كان وما يفيدان العموم و الاستمر ارية في الدعوة إلى الإســلام قبــلـ

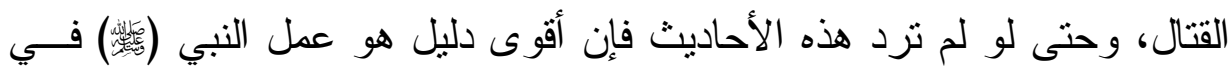

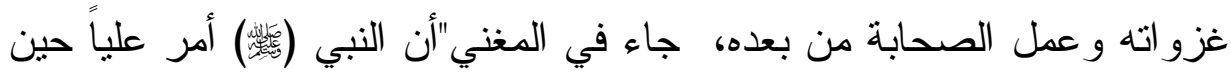
أعطاه الر اية يوم خيبر ، وبعثة إلى قتالهم أن بدعو هم، وهم ممن بلغتهم الـــدعوة.

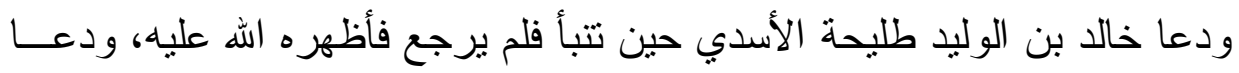

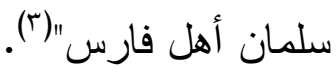

بعد ذللك تتبعنا الر اويات لنعرف سبب ورود الحديث، فوجدنا ســبب ورود

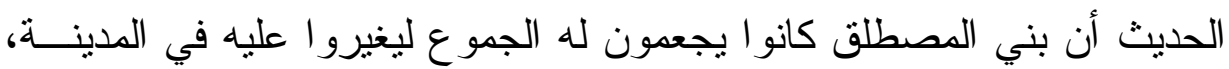

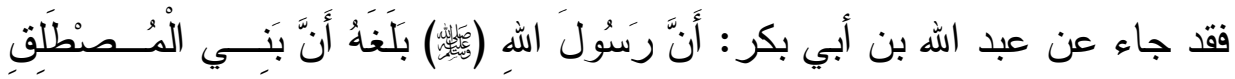

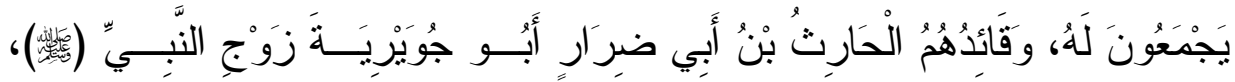

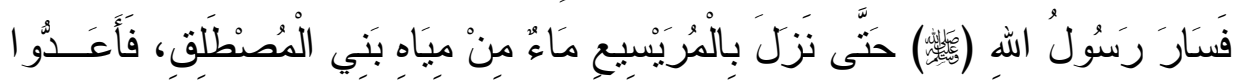

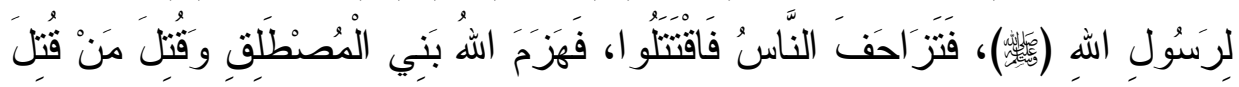

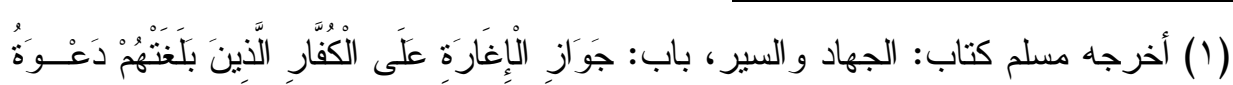

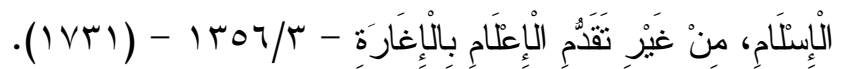

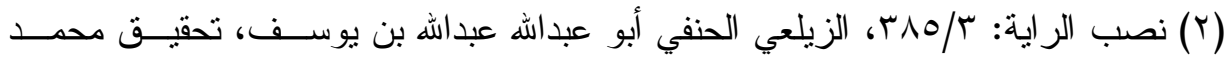
يوسف، مصر دار الحديث.

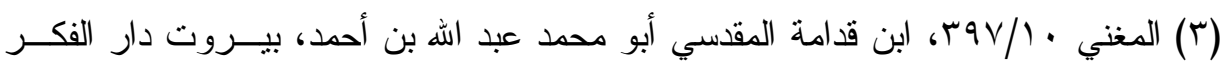




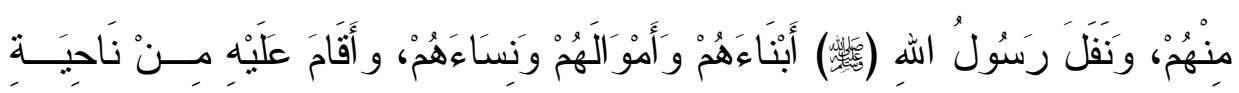

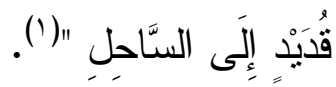

مما يعني أن الحديث يستدل به إذا اقترن معه سبب ورود الحديث فــي جهـاد

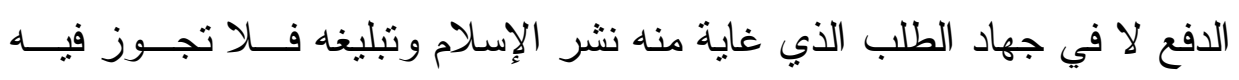
المباغتة بخلاف جهاد الدفع الذي الغاية منه رد الأعداء عن بلاد الإسلام.

$$
\text { (1) أخرجه البيهفقي في السنن الكبرى 10/9. }
$$




\section{المبحث الأول}

\section{كيفية إدراك هذا العلم}

لا بد في إدر الك أسباب الورود من الاعتماد علــى روايــة الــصحابي أو

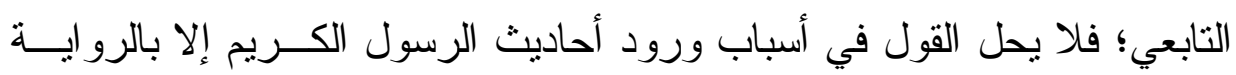

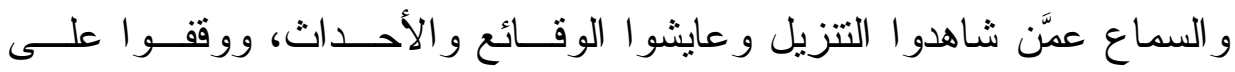

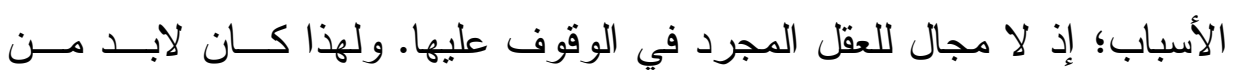

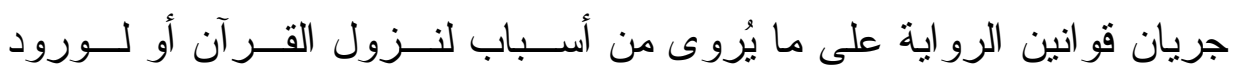

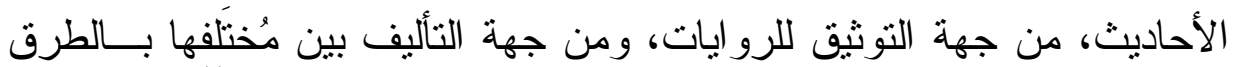
العلمية المعروفة لدى علماء الحديث.

و هنا ينبغي التتبه إلى أن الأمر الذي أخبر الصحابي أنه الباعث على نطــث

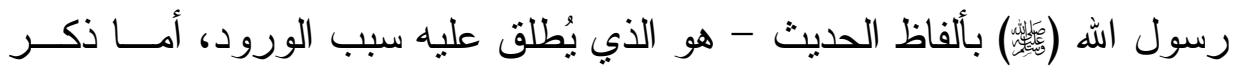

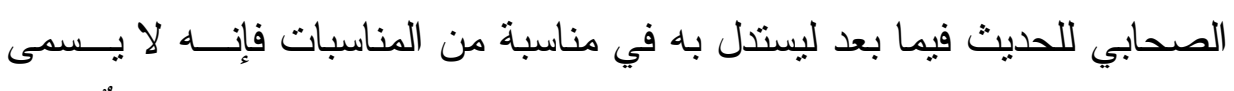

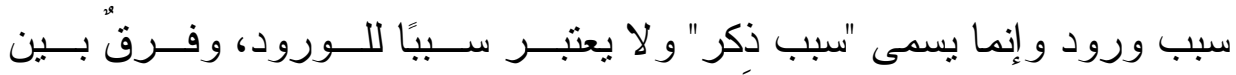

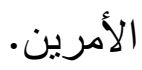




\section{المبحث|ثاني}

\section{الفرق بين سبب الورود وسبب الذكر}

فسبب ورود الحديث هو: علم يبحث فيه عن الأسباب الداعية إلـى ذكــر

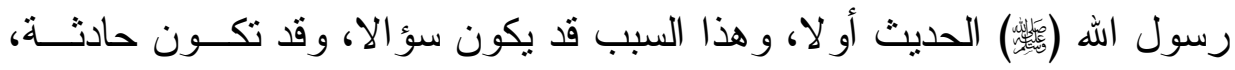
وقد تكون قصة، فيقول النبي (敬) الحديث بسبيه أو بسبيها. فهو السبب الذي لأجله قيل الحديث من أصله ومصدره، أي سبب صدوره عن القائل و هو النبي (赔)، ولهذا صنفت المصنفات المهتمة بهذا النوع ككتاب: ابن حمزة الحسيني (البيان و التعريف في أسباب ورود الحديث الثريف). أما سبب إير اد الحديث (ويسميه بعض العلماء سبب ذكر الحديث) فــالمر اد

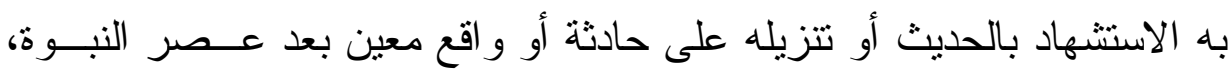

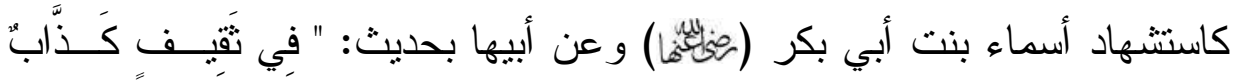
وَمَبِير"'(1)، عند حديثها مع الحجاج وقولها، أما الكذاب فقد رأيناه (تقصد المختار الثقي)، أما المبير فما أر اه إلا أنت.

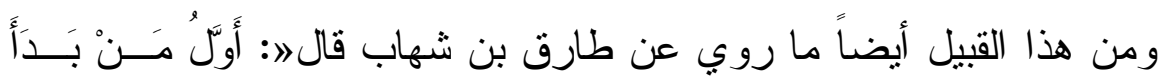

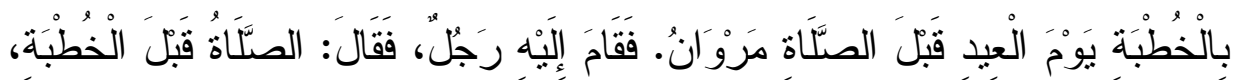

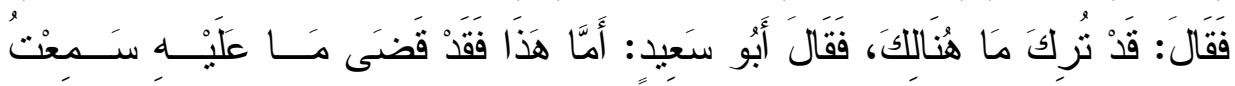

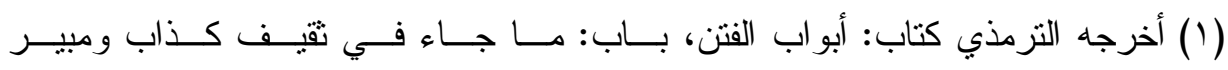

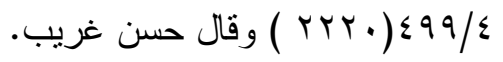




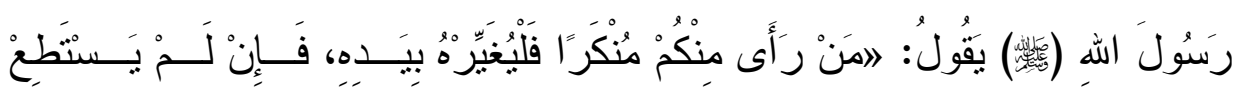

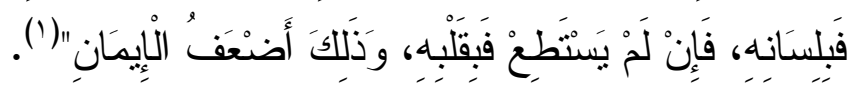

فأبو سعيد الخدري أورد هذا الحديث بما يتتاسب مع الحدث و الو اقعة، وهذا

$$
\text { ليس سبياً لورود الحديث!!!. }
$$

وقد يكون سبب الإير اد للعكس أي إنكار تتزيل حديث حمـلـ علــى غيــر محمله، وهذا وارد في إنكار الصحابة أو من جاء بعدهم تتزيل شخص الإن ما حديثاً على أمر ما فينكر هذا التتزيل، ويبين المر اد الصحيح للحديث، و غالباً ما يرنبط بتصحيحه هذا بالرجوع إلى سبب ورود الحــديث، فتـصحيح سـبـ الإيــر اد و الاستشهاد يكون بالاستعانة بسبب الورود و الله أعلم.

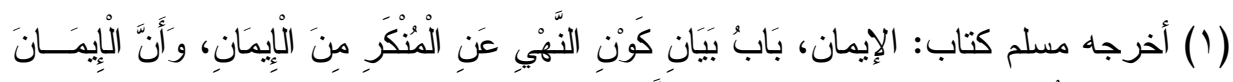

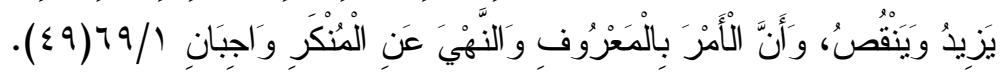




\section{المبحث الثالث}

\section{الفوائد المترتبة على مهرفة أسباب الورود}

يجمل بنا في هذا المبحث أن نذكر أبرز الفوائد المتحــصلة مــن معرفــة

أسباب ورود الحديث:

1- إدر الك حكم التشريع، ومعرفة مقاصد الثريعة، يعــــــــبـ الــورود

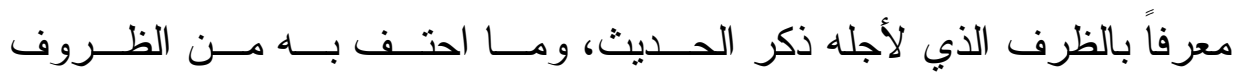
و الملابسات، وهذا يفيد كثير اً في مسألة الاجتهاد وتنزيل الأحكام علـــى الوقــائع و النوازل، ويعين في باب القياس وضم النظير إلى نظيره.

r- فهم الحديث على الوجه الصحيح، وســلامة الاســتباط منــه. قــال

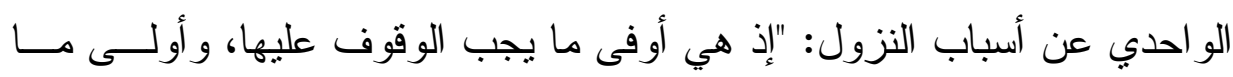

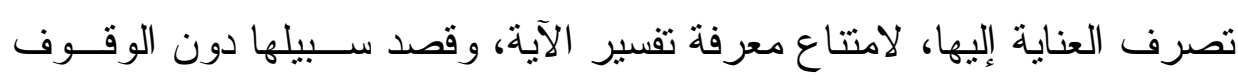

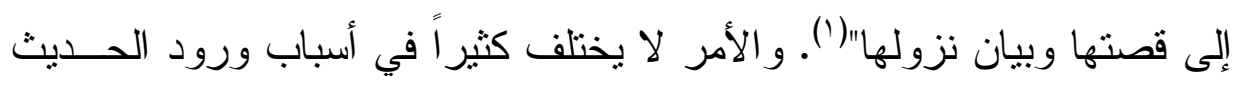
عنه في أسباب نزول القرآن، فالفقيه و المجتهد بحاجة ماسة إلى النظر في سبب ورود الحديث، حتى لا يحصل الخطأ في فهم النص ونتزيله على غير محلــه.

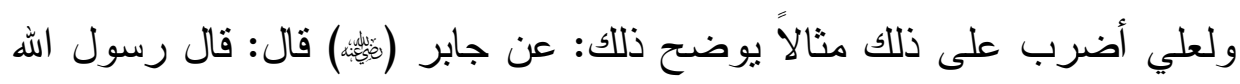

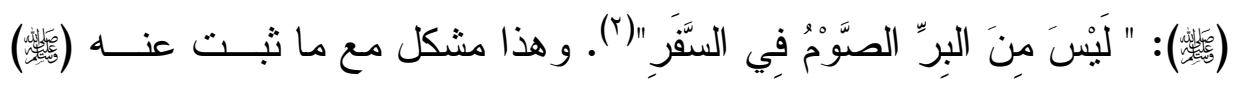

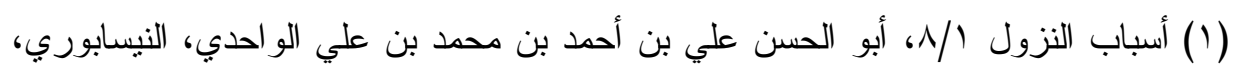

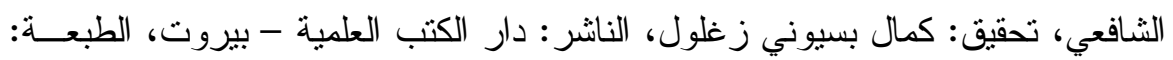

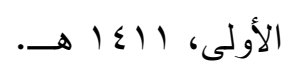

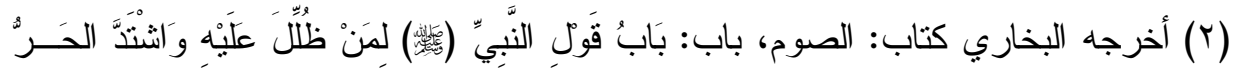

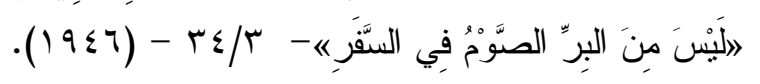




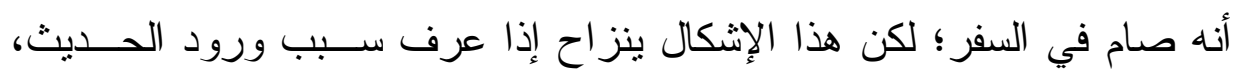

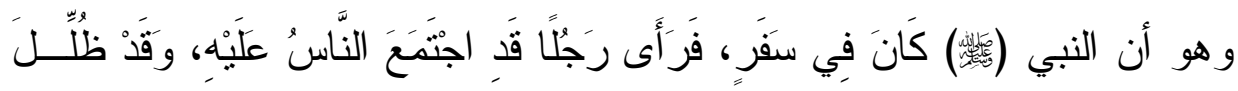

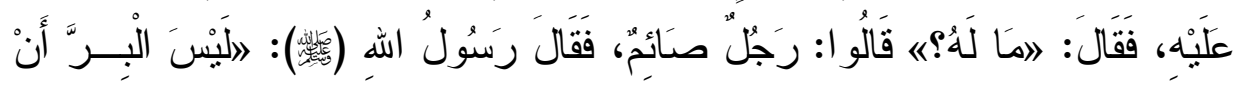

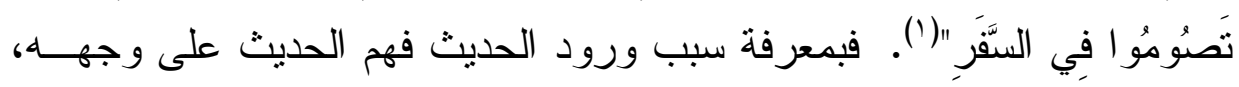
وسلم الاستتباط منه، و أن الصيام في السفر لا يكون من البر إذا بلغ بالمرءء مــن الجهر و المشقة كحال ذلك الرجل.

$$
\text { ז- ז- تخصيص العام. }
$$

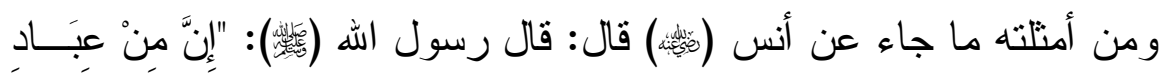

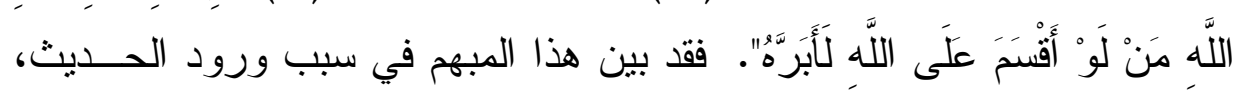
وذلك في قول أنس: كسرت الربيعُ - وهي عمة أنس بن مالك - ثنيــة جاريـــة

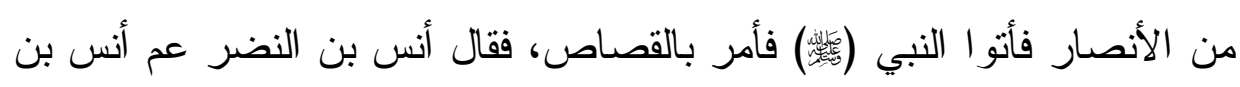

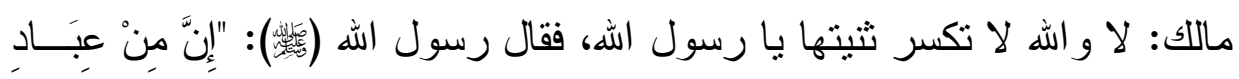

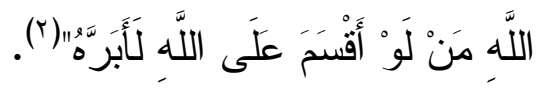

$$
\begin{aligned}
& \text { 0- إز الة الإشكال عن الرواية. }
\end{aligned}
$$

و إذا كان ابن دقيق العيد و السيوطي قد نبّها - كما مر - إلى هذه العلاقــة،

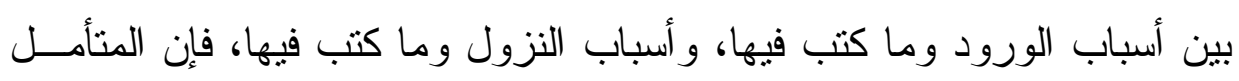

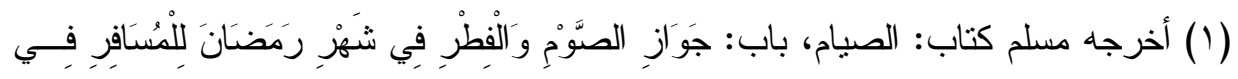

$$
\text { غَيْرِ مَنْصِيَةٍ - (1) }
$$

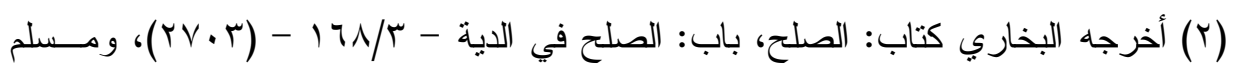

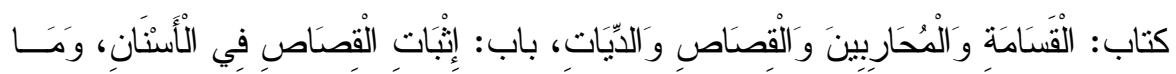

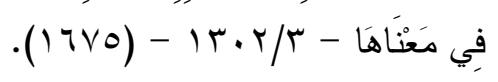


في هذه الكتابات، يجد أن المصنفين في أسباب النزول، هم المشتغلون بالروايات وما يتصل بعلوم الحديث؛ فقد ذكر الإمام الزركثي في كتابه "البرهان في علوم

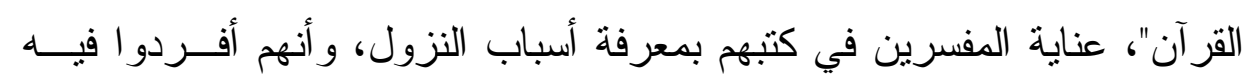

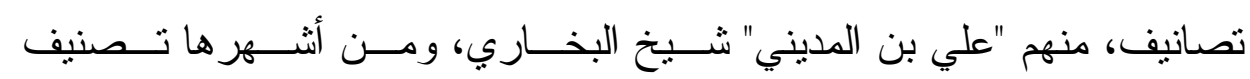
الو احدي. 


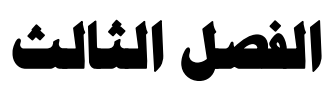

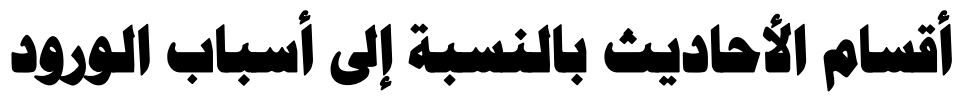

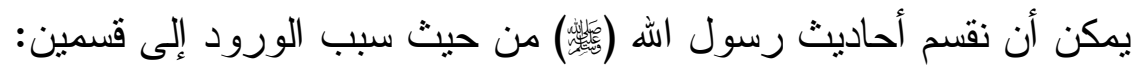

الأول: ماله سبب قيل لأجله واقتضى وروده، والثاني: ما لا سببَ لــه، وإنمـــا

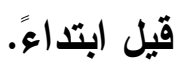

المبحرغ الأهل

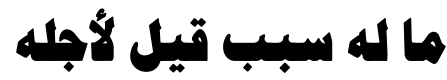

ومما سيق لسبب استدعى نُطق رسول الله تعالى به فهو موضـــوع بحنتــا،

ومن خلال بعض الأمثلة و النماذج التطبيقية نلقي الضوء علـى أســباب ورود

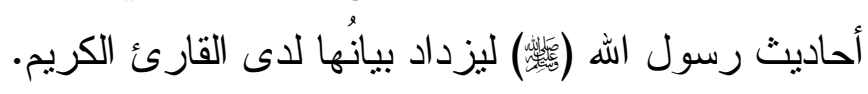

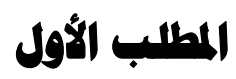 \\ النمبمذة الأول}

كانت الرقية في الجاهلية يكتتفها كثير من الثرك و الثعوذة و الاستعانة بغير الله تعالى، فلما جاء الإسـام نقل الناس من الكفــر و الــشرك وعبـــادة الأوتـــان و الأصنام إلى عبادة إله و احد لا شريك له، وحرّم على أتباعه الاستعانة بــالجن و الثياطين و الاستعاذة بهم، و أمر هم بالاستعانة بالله وحده و الاستعاذة به من شـــر لهر الثياطين ومن شر ما خلق أجمعين، وتبعًا لذلك فقد أقرّ من الرقية ما كان خاليا من الشرك و الاستعانة بغير الله، وحرّم ماسو اها. 


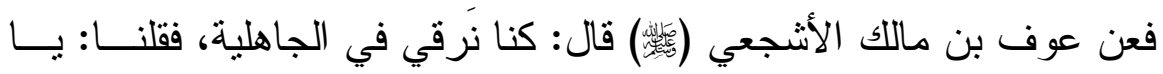

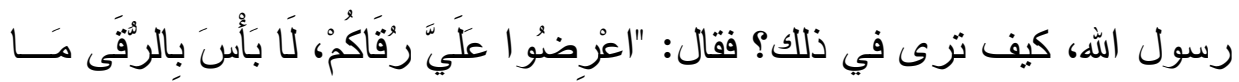

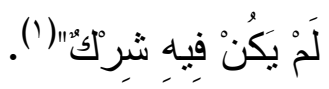

\section{ودود المديثث}

يروي لنا الصحابي الجليل عوف بن مالك (نوئَ) حال الناس قبل بعثة النبي

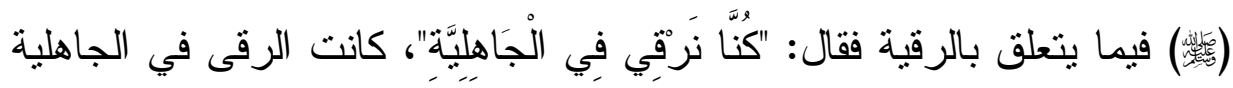

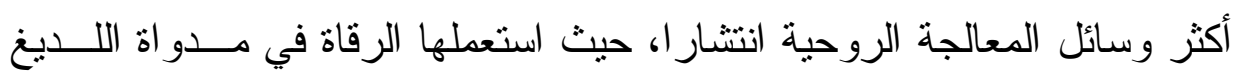
و المصاب بالعين أو السحر وغير ذللك، ولم يكن الرقاة من السحرة و العـر افين

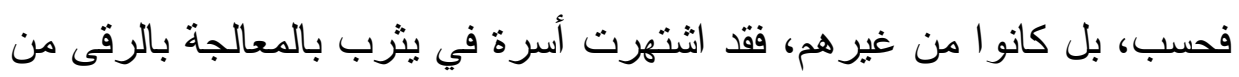

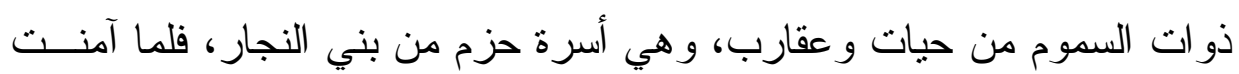

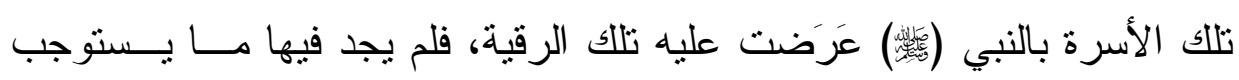
تحريمها فأجاز ها.

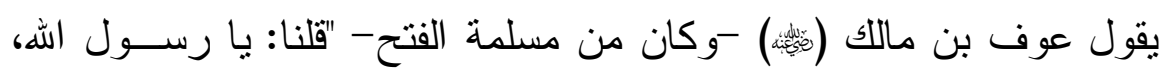
كيف ترى في ذلك؟": هذا تساؤل عن مدى مخالفة الرقية لشريعتتا، يقول جــابر

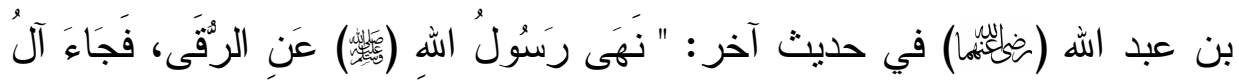

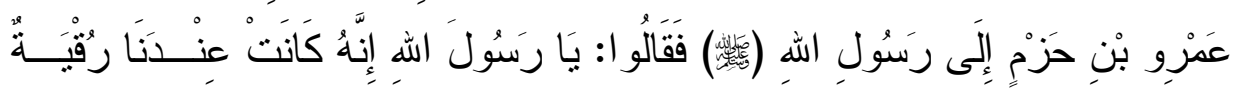

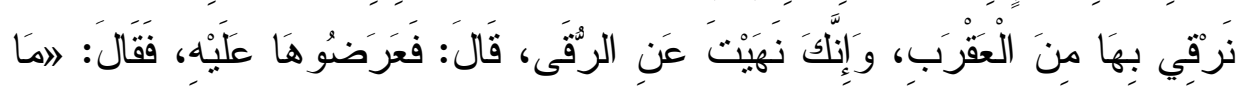

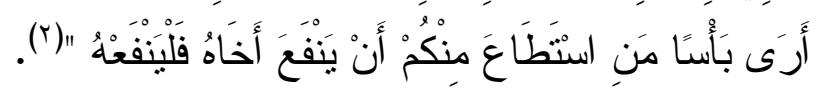

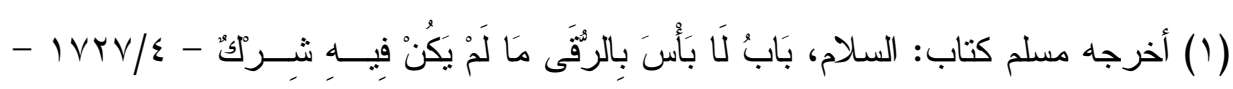

$$
\text { (r...) }
$$

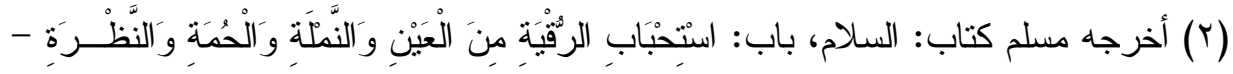

$$
.(r) 99)-1 \vee r T / \varepsilon
$$




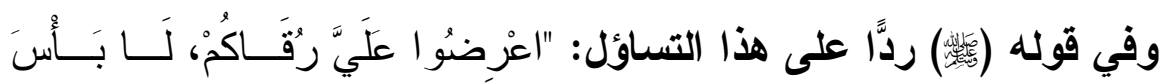

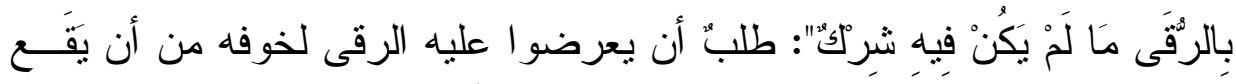

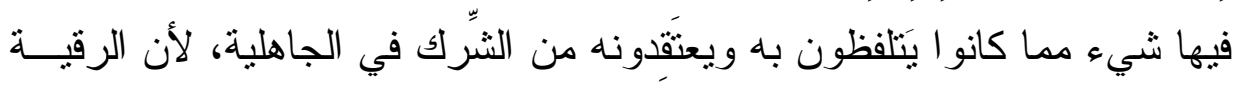

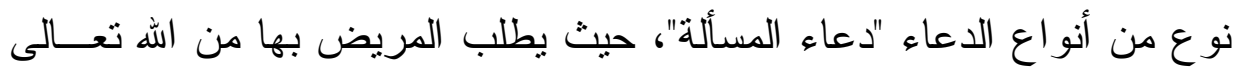

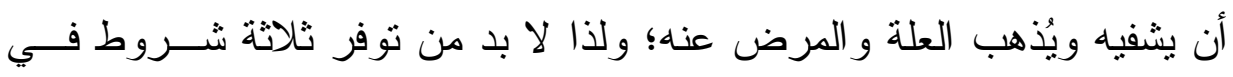

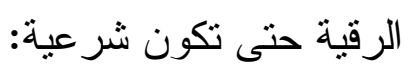

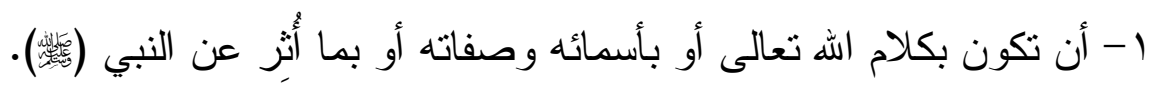
r- أن تكون باللسان العربي أو بما يعرف معناه من غيره. r- أن يعتقد أن الرقية لا نؤثز بذاتها.

\section{المطاب الثاني}

\section{النموذه الثاني}

كان صلح الحديبية وما تبعه من فتح مكة حدًا فاصلاً بين السابقين الأولــين

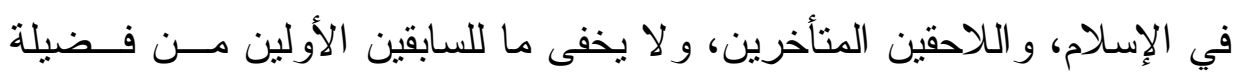

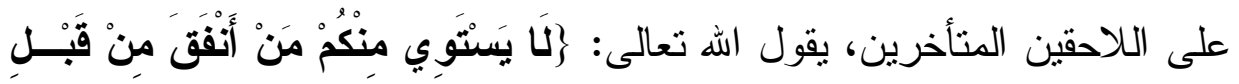

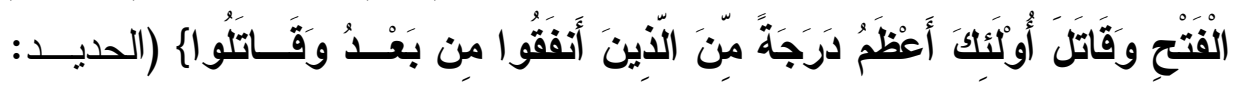
(1).

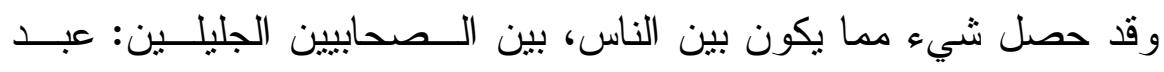

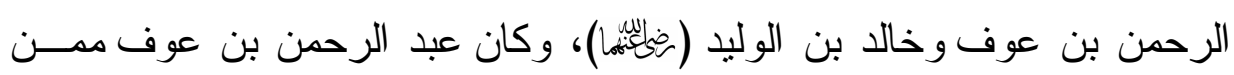

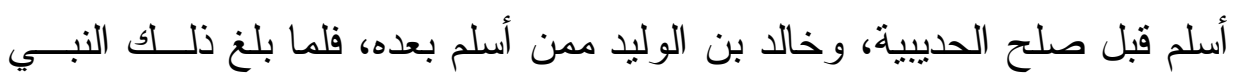


( قالِ

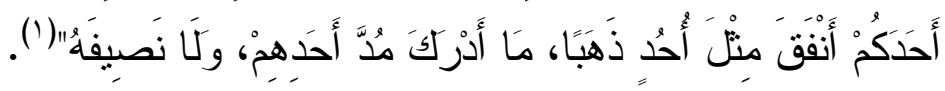

\section{ورود المديثث}

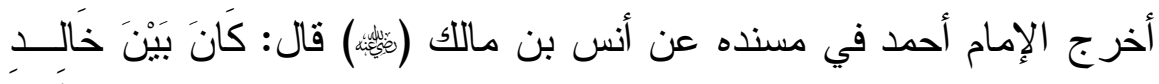

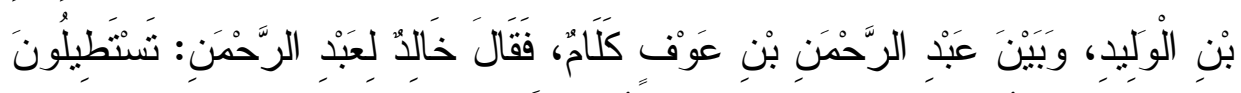

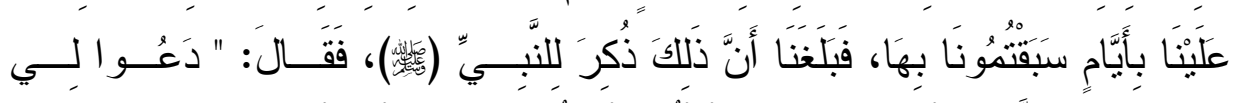

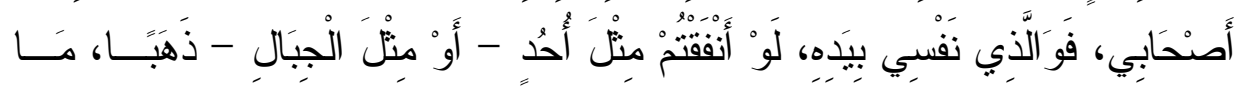

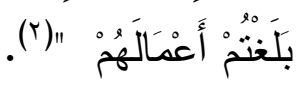

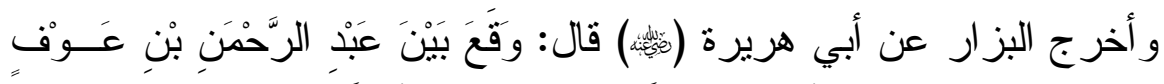

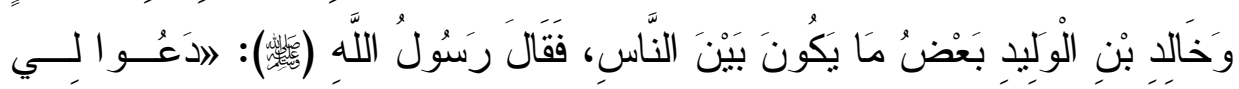

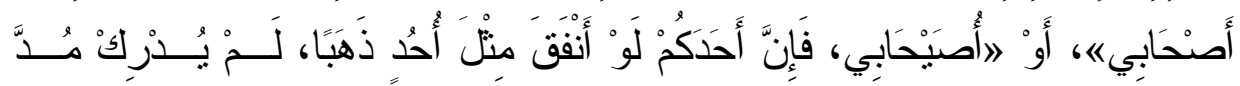

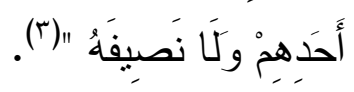

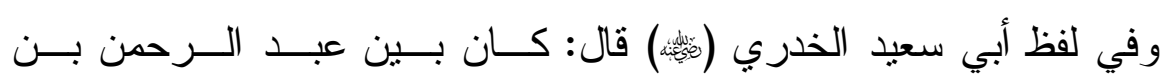

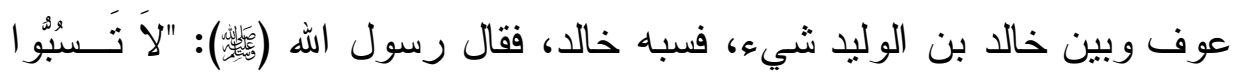

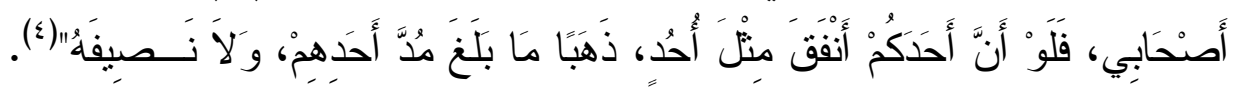

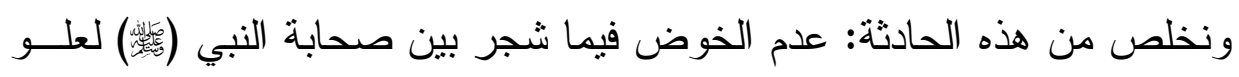

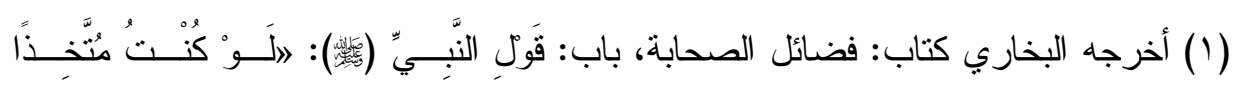

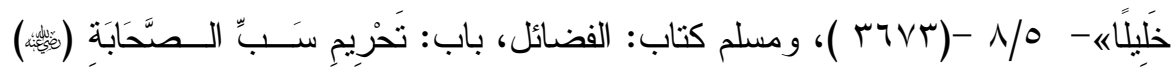

$$
\begin{aligned}
& .(\text { YOs.) - 197V/క }
\end{aligned}
$$

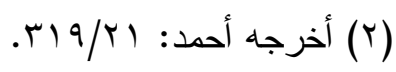

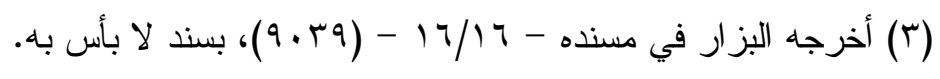

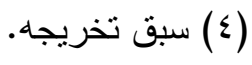


مكانتهم، وثناء القر آن على فضلههم، وسبقهم في نصرة الإسلام و أهلــهـ: يقــول

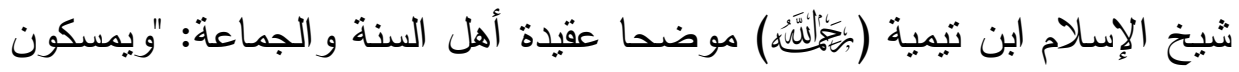
عما شجر بين الصحابة، ويقولون إن هذه الآثار المروية في مساوئهم منها مــــا هو كذب، ومنها ما قد زيد فيه ونقص، و غيّرَّ عن وجهه، و الصحيح منه هم فيه

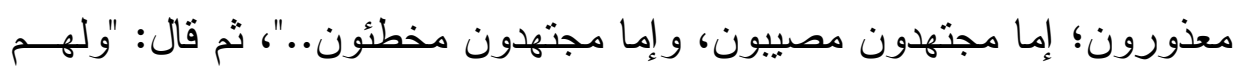

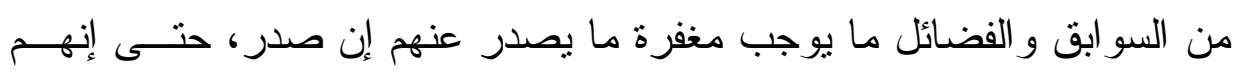
يغفر لهم من السيئات ما لا بغفر لمن بعدهم؛ لأن لهم من الحسنات التي تمحسبـ

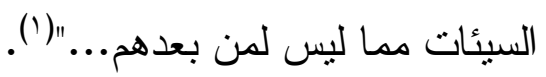
وقال أيضا: "ثم القَذر الذي يُنكر من فعل بعضهم قليل نزرٌ مغفور" في جنب

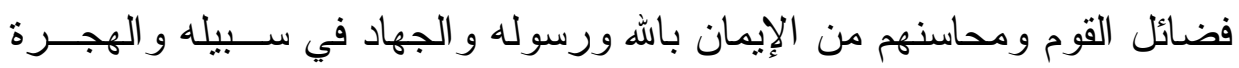

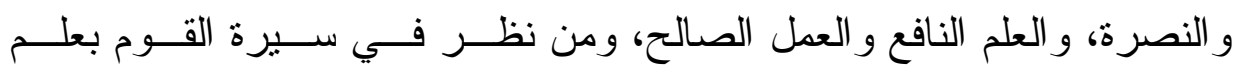

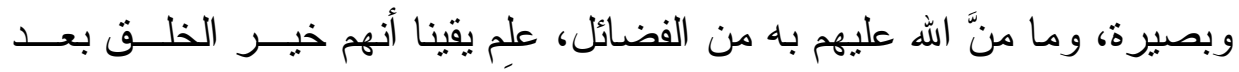

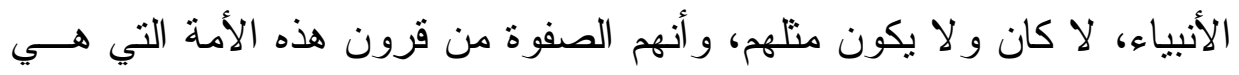

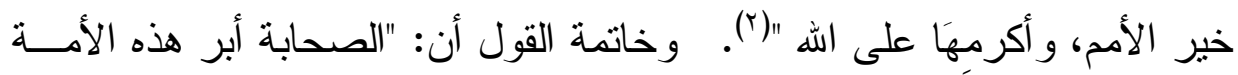

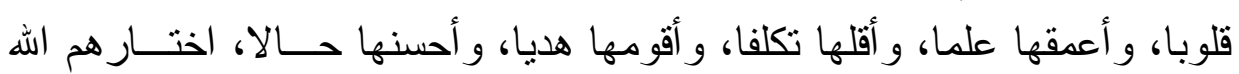

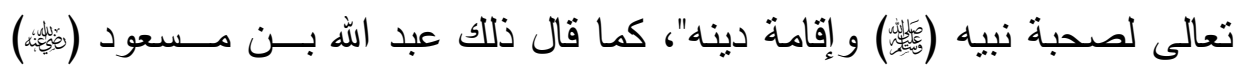

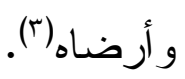

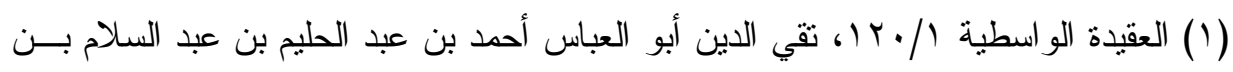

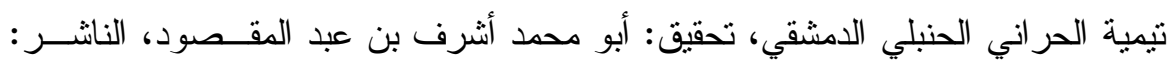

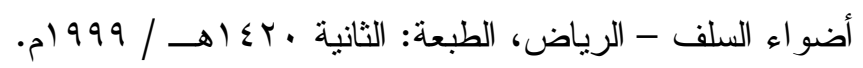

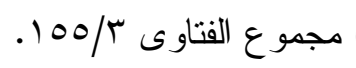

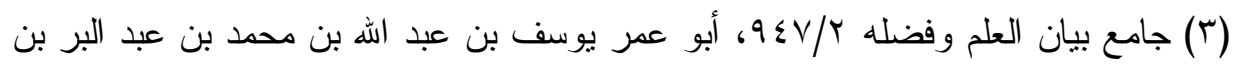

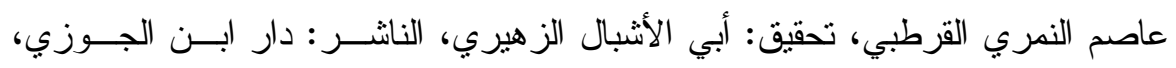

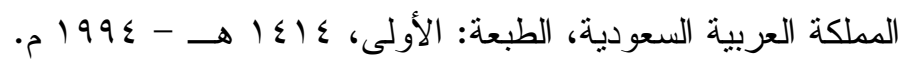




\section{المبحث الثاني}

\section{ها لا سبب 'له، وإنها قيل ابتداك"}

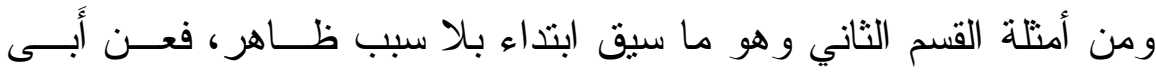

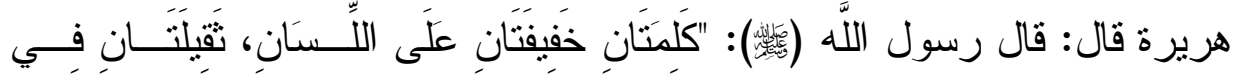

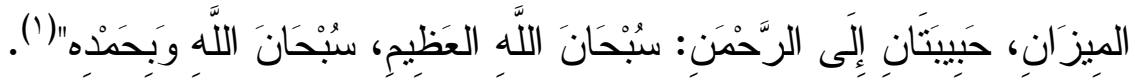

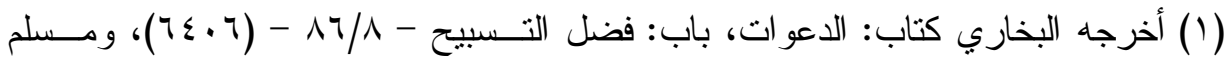

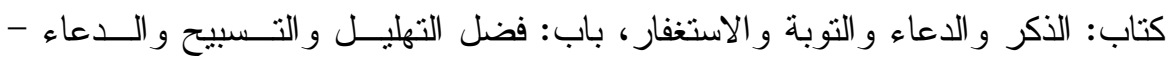

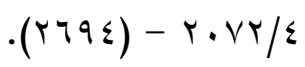




\section{نे}

الحمد لله الذي بنعمته تتم الصـالحات، و الحمد لله الذي يسر لنا إتمــام هــــا البحث على هذه الصورة المرضية، ونسأل اله أن يكون هــذا البحـــث إضــافة

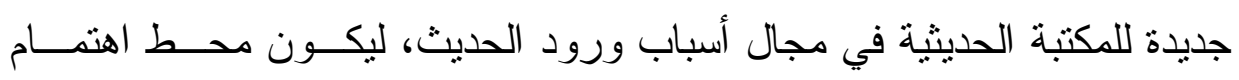

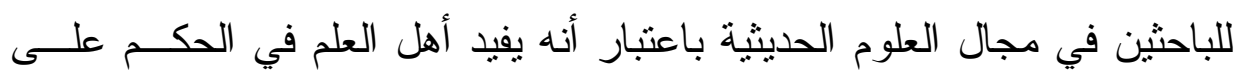
المسائل الفقهية إذا تبين لهم معرفة سبب ورود الحديث، وتحتوى هذه الخاتمــة

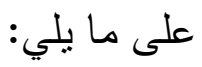

\section{أولا: ملخص البحث:}

يتلخص هذا البحث بأن عرفنا علم أسباب ورود الحديث، ثم تكلمنا عن قلة اهتمام المحدثين و الأصوليين بأسباب ورود الحديث، وبينا أن أسباب ذلك يعــود إلى صعوبة إحصاء أسباب ورود الحديث، و غياب أهمية أسباب ورود الحـديث عند الصحابة، وزعم البعض عدم أهميــة أســباب ورود الحــديث، و اعتبـــار

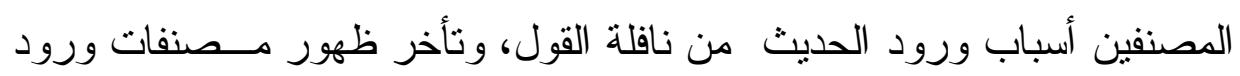

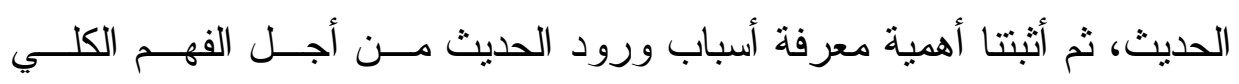

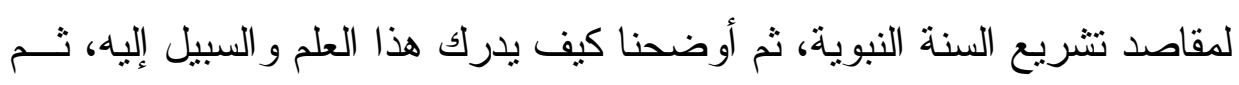
فرقنا بين سبب ورود الحديث، وسبب ذكر الحديث،، ثم ذكرنا أقـسام الحــديث

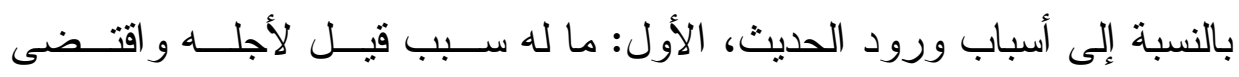

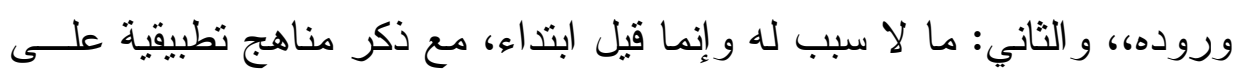
ذلك،، ثم ختمنا بحثنا بالفو ائد المترنبة على معرفة أسباب ورود الحديث. 
ثانيا: أهم نتائج البحث:

\section{تتلخص أهم نتائج البحث فيما يلي:}

1- إن السبب الأكثر تأثثر ا في إهمال أسباب ورود الحديث حين الاستتباط هو عدم ذكر أسباب الورود مع منون الحديث وشروحه.

r- استكمال آلة الاجتهاد و استيفاء الثروط التي يذكرها العلماء فيمن ينظر في نصوص الوحيين لاستتباط ما تدل عليه من حكمٍ و أحكام.

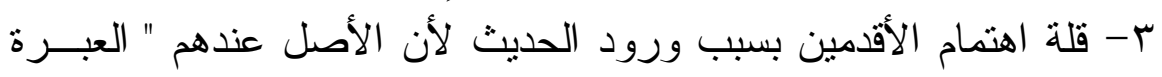

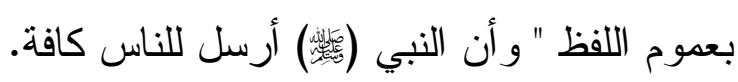
ع - من أسباب قلة اهتمام السابقين بورود الحديث استحالة مكــث جميـع

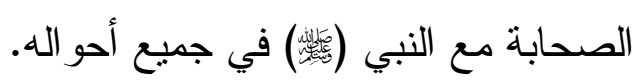

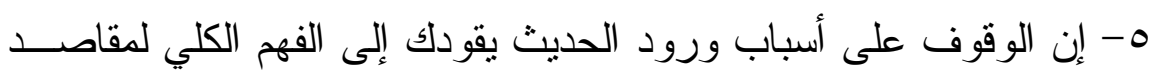
تشريع السنة النبوية.

7- مذهب أم المؤمنين عائثة (مغأقما) هو وجوب ذكر سبب ورود الحديث

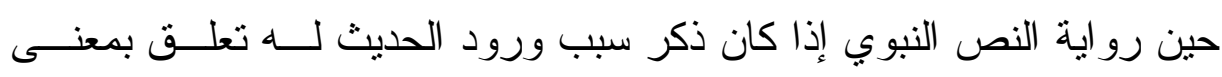
الحديث.

- V أهمية تقييد قاعدة "العبرة بعدوم اللفظ لا بخصوص الــسبب" بقاعـدة

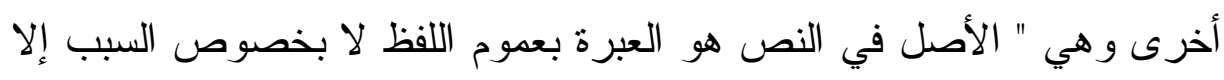
إذ كان أسباب النزول أو ورود الحديث يخصصان النص أو الفعل".

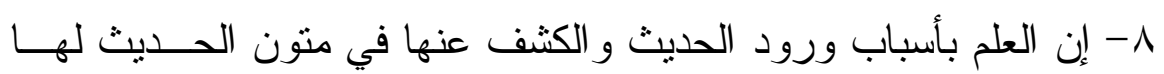
ارتباط وثيق في استتباط حيثيات الأحكام الفقهية.

9- إن معرفة أسباب ورود الحديث قد يخصص الحكم على صورة معينة، و إن كان لفظ الحديث عاما. 
أهم التوصيات:

ويمكن أن نجمل أهم التوصيات والمقترحات فيما يلي:

1- تتظيم حلقات نقاثية بين أصحاب التخصص في مجال الحديث النبــوي

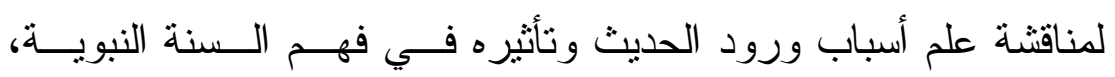

$$
\text { وتأثنير ها في تغيير الحكم الفقهي }
$$

r- عقد مؤتمر علمي موسع على مستوى الدول الإسلامية و العربية لبحـــث

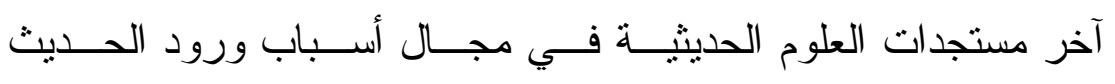

$$
\text { ومتعلقاتها في فهم مقاصد تشريع السنة النبوية. }
$$

ب- توجيه رسائل قصيرة عبر المؤسسات الحكومية المهتمـــة بالر عايـــة

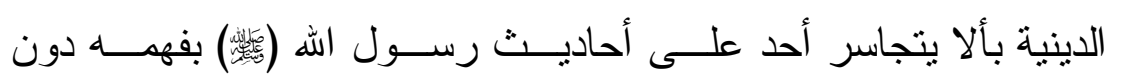
الرجوع إلى أهل العلم، و الوقوف على سبب ورود الحديث، حتى لا نقع

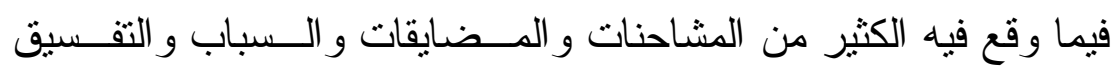

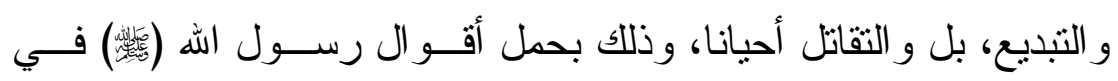

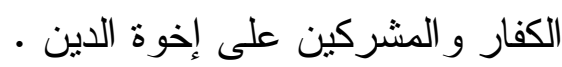

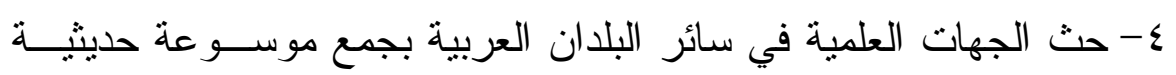

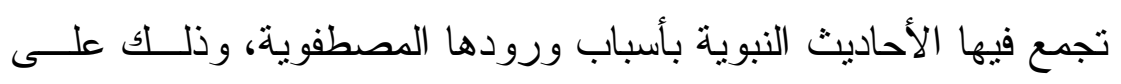

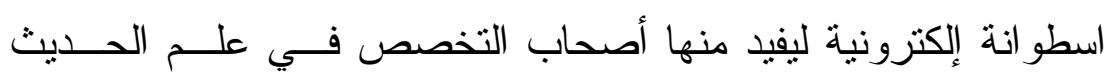
الثريف.

\section{كثبه العبد الفقم}

\section{د. هممد يوسف الشطي}

\section{د.إبراهيم مممد مصمد عبد العال المناوي هي}




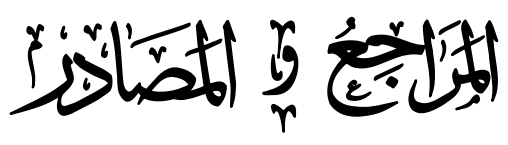

* الروح في الكلام على أرواح الأموات و الأحياء بالدلائل من الكتاب و الــــنة،

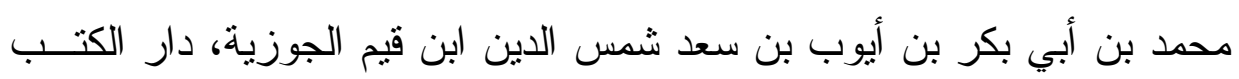

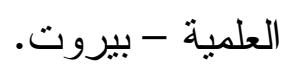

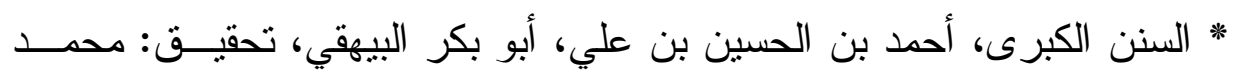
عبد القادر عطا

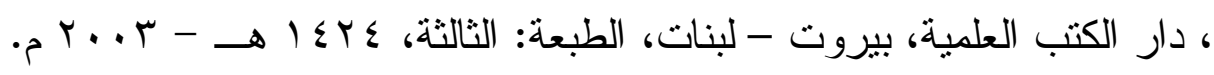

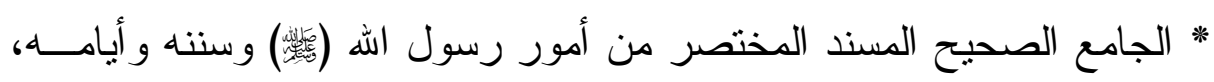

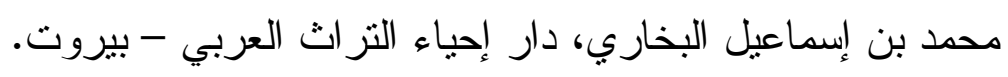

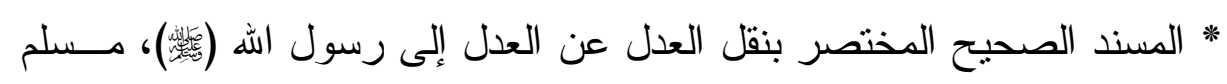

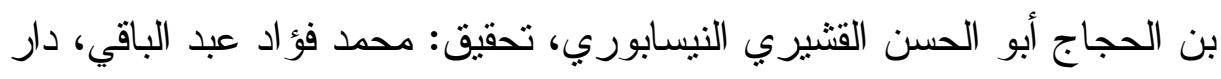
إحياء النزاث العربي - بيروت.

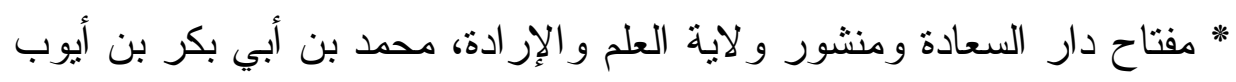
بن سعد شمس الدين ابن قيم الجوزية، دار الكتب العلمية - بيروت.

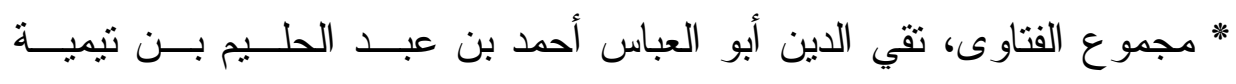

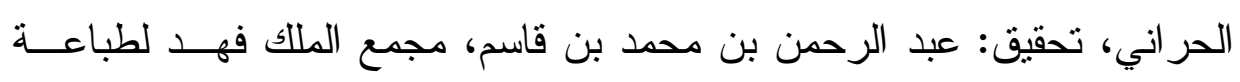

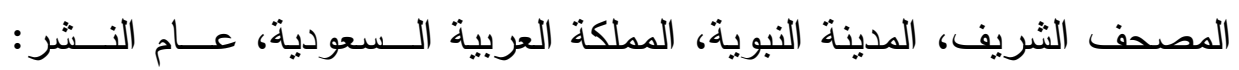

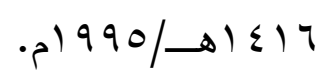

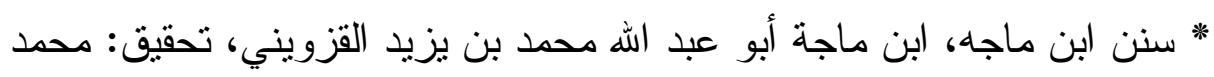
فؤاد عبد الباقي، دار إحياء الكتب العربية - فيصل عيسى البابي لهيد الحلبي. 
* سنن أبي داود، أبو داود سليمان بن الأشعث بن إسحاق بن بشير بن شداد بن

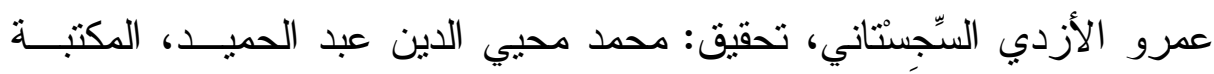

$$
\text { العصرية، صيدا - بيروت. }
$$

* سنن الترمذي، محمد بن عيسى بن سَوْرة بن موسى بن الضحاك، الترمذي،

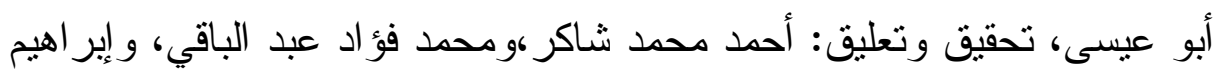
عطوة عوض المدرس في الأزهر الثريف، شركة مكتبة ومطبعــة مــصطفى

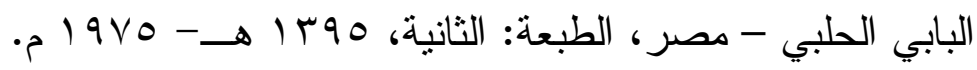

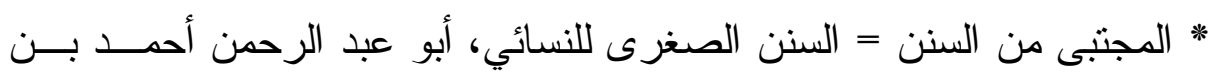

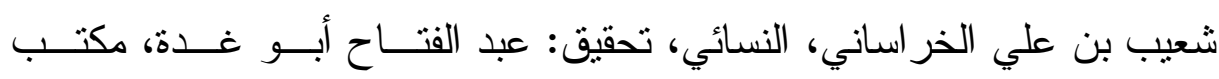

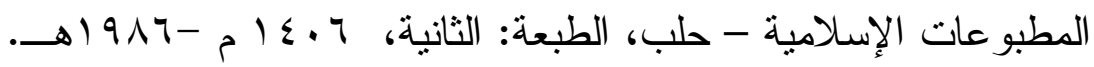

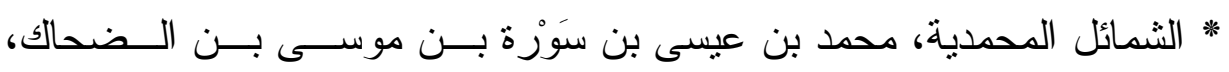
الترمذي، أبو عيسى، دار إحياء التراث العربي - بيروت.

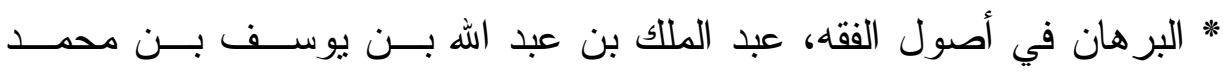

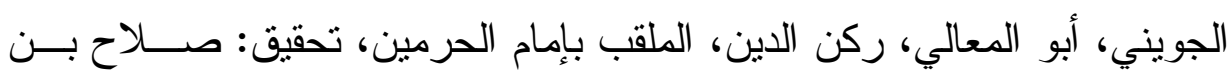

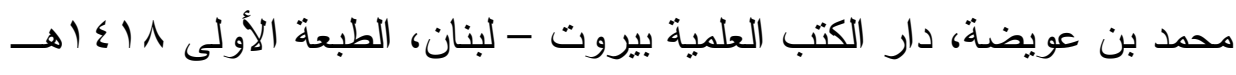
. $199 V-$ * الإحكام في أصول الأحكام، أبو الحسن سيد الدين علي بن أبي علي بن محمد

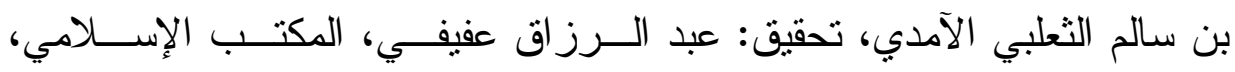
بيروت - دمشق - لبنان. * البرهان في علوم القرآن، أبو عبد الله بدر الدين محمد بن عبد الله بن بهــادر

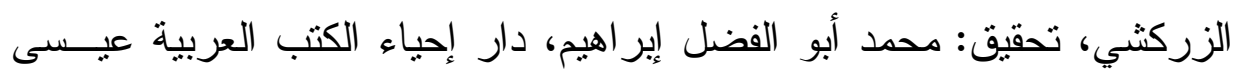
البابى الحلبي وشركائه، الطبعة: الأولى، 
* الإتقان في علوم القرآن، عبد الرحمن بن أبي بكر، جلال الــدين الـسيوطي،

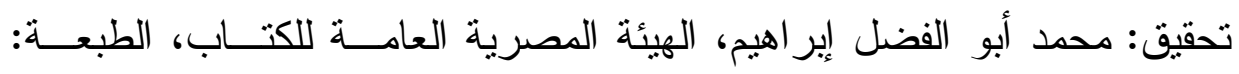

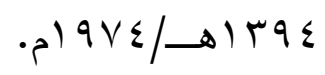

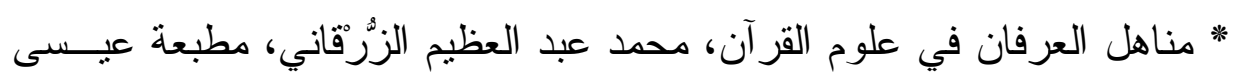
البابي الحلبي وشركاه، الطبعة الثالثة.

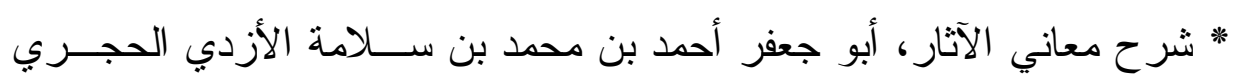

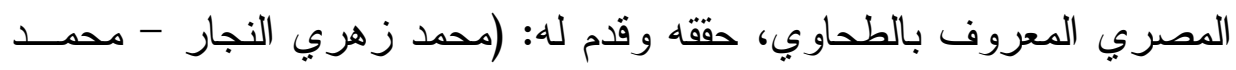
سيد جاد الحق) من علماء الأزهر الثريف، راجعه ورقم كتبه و أبو ابه و أحاديثه: د يوسف عبد الرحمن المرعشلي - الباحث بمركز خدمة السنة بالمدينة النبوية،

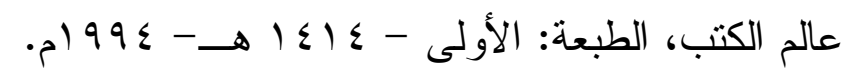
* أصول في أصول الفقه، ابن العربي، أبو بكر المعافري المــالكي، تحقيـق:

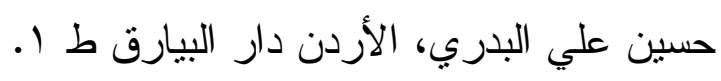
جامع البيان في تأويل القرآن، محمد بن جرير بن بزيد الآملي، أبـــو جعفــر

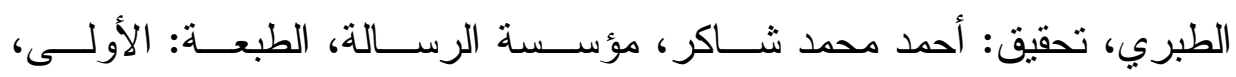
. $r . .-\rightarrow$. $1 \leq r$. * المصنف، أبو بكر عبد الرزاق بن همام بن نافع الحميري اليماني الصنعاني،

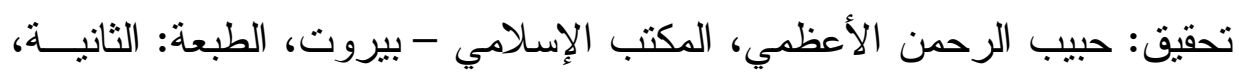
$\rightarrow$. * مسند أبي يعلى، أبو بعلى أحمد بن علي بن المثُتى بن بحيى بن عيـسى بــن

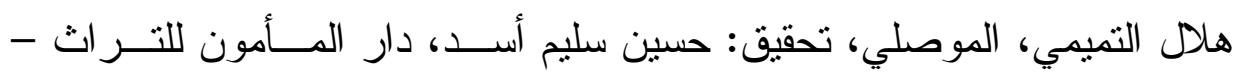

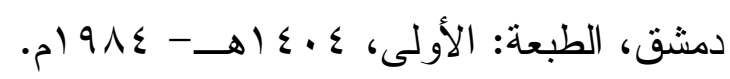




\section{الدكتور / محمد يوسف الشطي و الدكتور / إبراهيم محمد محمد عبد العال الحناوي}

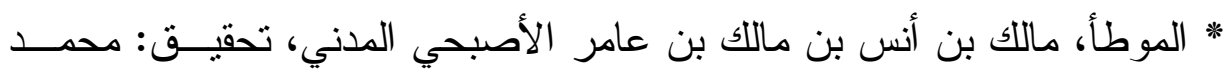

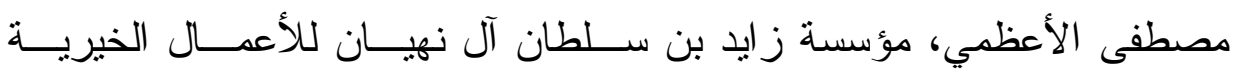

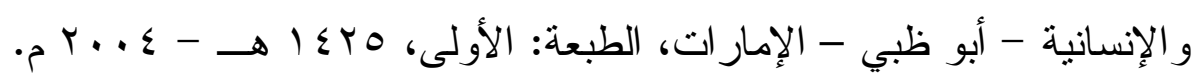

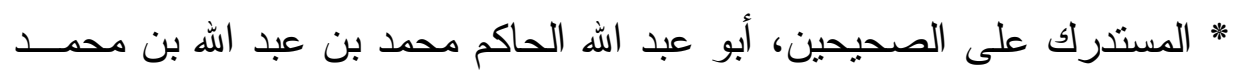
بن حمدويه النيسابوري المعروف بابن البيع، تحقيق: مصطفى عبد القادر عطا،

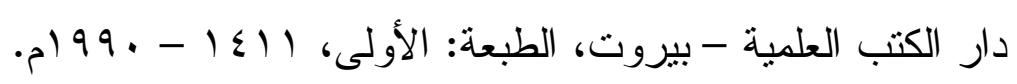

* معرفة السنن و الآثار، أحمد بن الحسين بن علي بن موســى الخُسـرْوَجْردي الخر اسـي، أبو بكر البيهقي، تحقيق: عبد المعطي أمسـين قلعجـي، الناثــرون: جامعة الدر اسات الإسلامية (كر اتثي - باكستان)، دار قتيبة (دمشق -بيروت)،

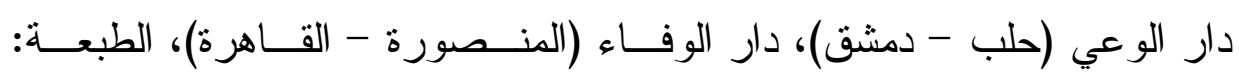

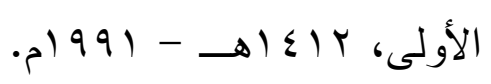

* النكت على مقدمة ابن الصلاح، أبو عبد الله بدر الدين محمد بن عبد الله بـن

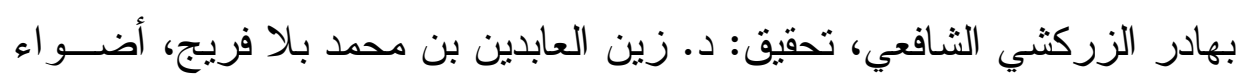

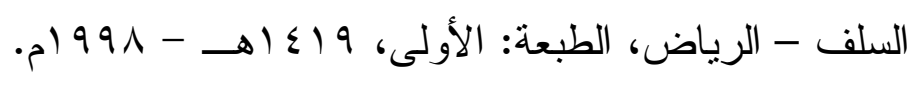
* القو اعد و الفوائد الأصولية ومايتبعها من الأحكام الفرعية، ابن اللحام، عــلاء الدين أبو الحسن علي بن محمد بن عباس البعلي الدمشقي الحنبلي، تحقيق: عبد

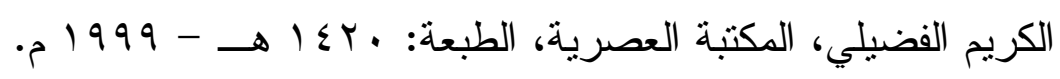
* الجامع لأحكام القرآن، أبو عبد الله محمد بن أحمد بن أبي بكــر بــن فــرح الأنصاري الخزرجي شمس الدين القرطبي، تحقيق: أحمد البردونــي و إبــر اهيم

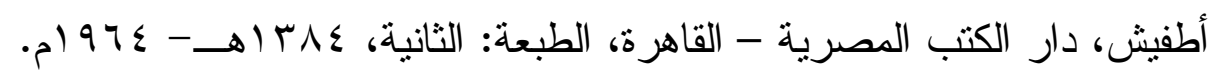


* المعجم الأوسط، سليمان بن أحمد بن أيوب بـن مطيــر اللخمــي الــشامي،

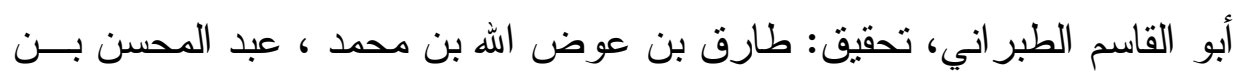

$$
\text { إير اهيم الحسيني، دار الحرمين - القاهرة. }
$$

* المعجم الكبير، الطبر اني، تحقيق: حمدي بن عبد المجيد السلفي، دار النـشر : مكتبة ابن تيمية - القاهرة، الطبعة: الثانية.

* نصب الر اية لأحاديث الهداية مع حاثيته بغية الألمعي في تخريج الزيلعـي،

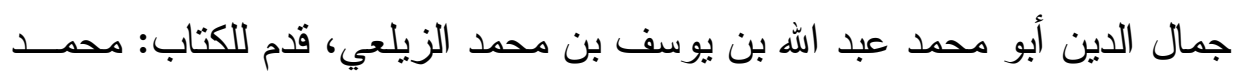

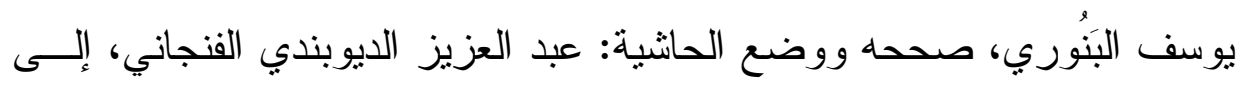
كتاب الحج، ثم أكملها محمد يوسف الكاملفوري، المحقق: محمد عو امة، مؤسسة

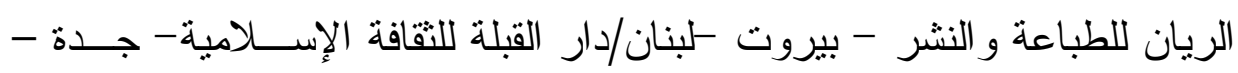

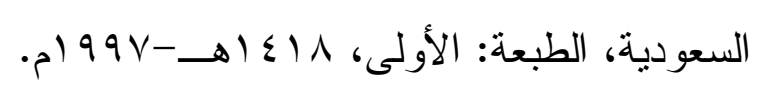

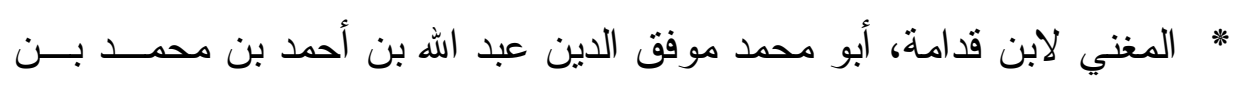

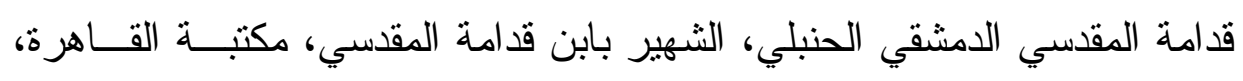
الطبعة: بدون طبعة.

* مسند الإمام أحمد بن حنبل، أبو عبد اله أحمد بن محمد بن حنبل بن هلال بن أسد الثيباني، تحقيق: شعيب الأرنؤوط - عادل مرشد، و آخــرون، إثــــر اف:

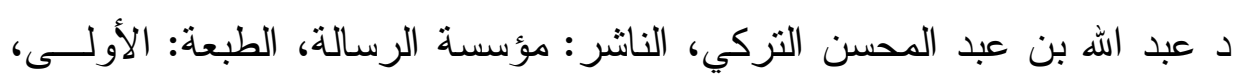

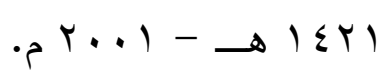

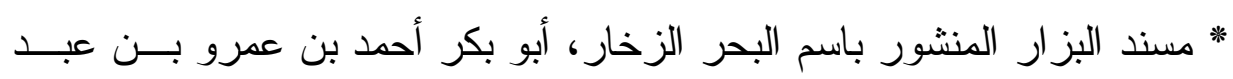

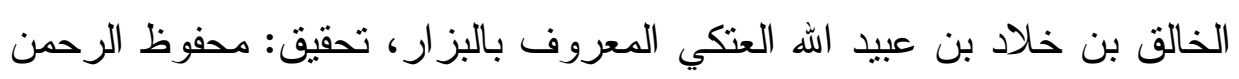

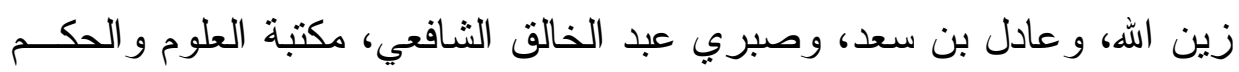
- المدينة المنورة، الطبعة: الأولى. 
* العقيدة الو اسطية: اعتقاد الفرقة الناجية المنصورة إلى قيام الساعة أهل السنة و الجماعة، تقي الدين أبو العباس أحمد بن عبد الحليم بن عبد السلام بن عبد الهه

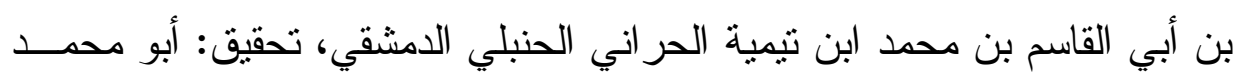

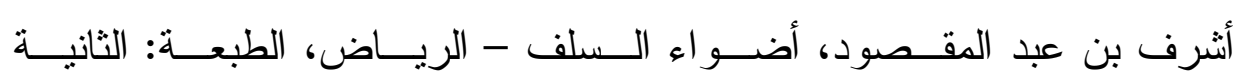
. $999 / \rightarrow 1 \leqslant r$. * أسباب نزول القرآن، أبو الحسن علي بن أحمد بن محمد بن علي الواحــدي،

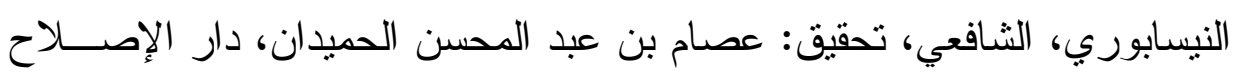

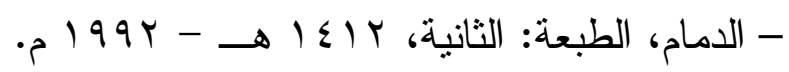




\section{فهرس الموضوعات}

\begin{tabular}{|c|c|}
\hline |لصفحة & الموضوع \\
\hline$r$ & المقدمة \\
\hline 10 & الفصل الأول: قلة اهتمام الأقدمين بأسباب ورود الحديث \\
\hline 19 & المبحث الأول: صعوبة إحصاء أسباب الورود. \\
\hline$r \cdot$ & المبحث الثاني: غياب أهمية أسباب ورود الحديث عند الصحابة \\
\hline ro & المبحث الثالث: زعم البعض عدم أهمية ورود سبب الحديث \\
\hline r. & القول المبحث الرابع: اعتبار المصنفين أسباب ورود الحديث من نافـــة \\
\hline rr & المبحث الخامس: تأخر ظهور مصنفات ورود سبب الحديث \\
\hline r & المقاصد الثاني: أهمية معرفة ورود الحديث من أجل الفهـــم الكالـي \\
\hline q & المبحث الأول: كيفية إدرا(ك هذا العلم \\
\hline MV & المبحث الثاني: الفرق بين سبب الورود وسبب الأكر \\
\hline rq & المبحث الثالث: الفوائد المترتبة على معرفة أسباب الورود \\
\hline$\leqslant Y$ & الفصل الثالث: أقسام الأحاديث بالنسبة إلى أسباب الورود \\
\hline$\leqslant Y$ & المبحث الأول: ما له سبب قيل لأجله \\
\hline
\end{tabular}


الدكتور / محمد يوسف الشطي و الدكتور / إبراهيم محمد محمد عبد العال الحناوي

\begin{tabular}{|c|c|}
\hline$\varepsilon r$ & المطلب الأول: النموذج الأول \\
\hline$\varepsilon \varepsilon$ & المطلب الثاني: النموذج الثاني \\
\hline$\varepsilon V$ & المبحث الثاني: ما لا سببَ له، و إنما قيل ابتداءً \\
\hline$\leqslant 1$ & 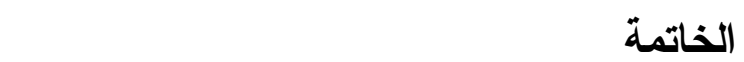 \\
\hline 01 & المصادر والمر اجع \\
\hline OV & فهرس الموضوعات \\
\hline
\end{tabular}
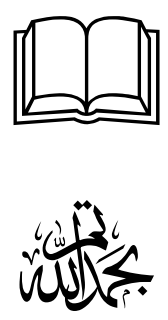
$-09$. 
الدكتور / محمد يوسف الشطي و الدكتور / إبراهيم محمد محمد عبد العال الحناوي

$-7 \cdot-$ 